\title{
Progress Report of the National Weatherization Assistance Program
}

\author{
Linda G. Berry \\ Marily A. Brown \\ Laurence F. Kinney* \\ * Symertech Systems Corporation
}

September 1997

\author{
Prepared for the \\ Office of State and Community Programs \\ Office of Burilding Technology, State and Community Programs \\ U. S. Department of Energy \\ Under the Direction and Supervision of \\ Jeanne Van Vlandren \\ Director, Office of State and Community Programs
}

\author{
Prepared by the \\ Oak Ridge National Laboratory \\ Oak Ridge, Tennessee 37831 \\ Managed by \\ Lockheed Martin Energy Research Corp. \\ for the \\ U. S. Department of Energy \\ Under Contract DE-AC05-960R22464
}




\section{INCREASES IN PROGRAM ENERGY SAVINGS AND COST EFFECTIVENESS (1989-1996) AT A GLANCE}

ENERGY SAYINGS IN GAS-HEATED HOMES

Eirstyear_sayings

1989 (PRISM analysis of billing data for hornes in the representative national sample that heat with gas)

1996 (national estimate derived from Metaevaluation of 17 state-level evahuations of savings in gas-heated homes)

VALUE OF GAS ENERGY SAVINGS (in 1996 dollars)

1989

1996

COST EFFECTIVENESS

Program Benefit/Cost Ratio a

Installation Benefit/Cost Ratio b

Societal Benefit/Cost Ratio ${ }^{\mathrm{c}}$
Percent of

Savings per

dwelling

$17.3 \mathrm{Mbou}$

31.2 Mbtu

$23.4 \%$

$33.5 \%$

$18.3 \%$
Percent of gas space heat consumption

$13.0 \%$

Eirst year

20 veans

$\$ 107 /$ dwelling $\$ 193 /$ dwelling

$\$ 1,707 /$ dwelling $\$ 3,047 /$ dwelling

- The program benefit/cost ratio compares the discounted value of the energy savings to total program costs with an assumed lifetime of 20 years and a discoumt rate of $4.7 \%$.

- The insfallation benefit/cost ratio compares the discounted value of energy savings to installation (labor and materials) costs with an assumed lifetime of 20 years and a discount rate of $4.7 \%$.

- The societal benefit/cost ratio compares the discounted value of both entergy and nonenergy benefits (such as employment and environmental impacts) to total program costs with an assumed lifetime of 20 years and a discount rate of $4.7 \%$. 


\section{DISCLAIMER}

Portions of this document may be illegible electronic image products. Images are produced from the best avallable original document. 


\section{CONTENTS}

The Natlonal Weatherlzation Evaluation of the 1989 Program Year and the Metaevaluation of 1996 are described in two ways in thls summary document. The text on the right-hand (odd) pages summarizes the results of the two evaluatlons conducted by the OakRidge National Laboratory. The photographs and explana tons on the left-hand(even) pages Illustrate weatherlzation operations and tactlos.

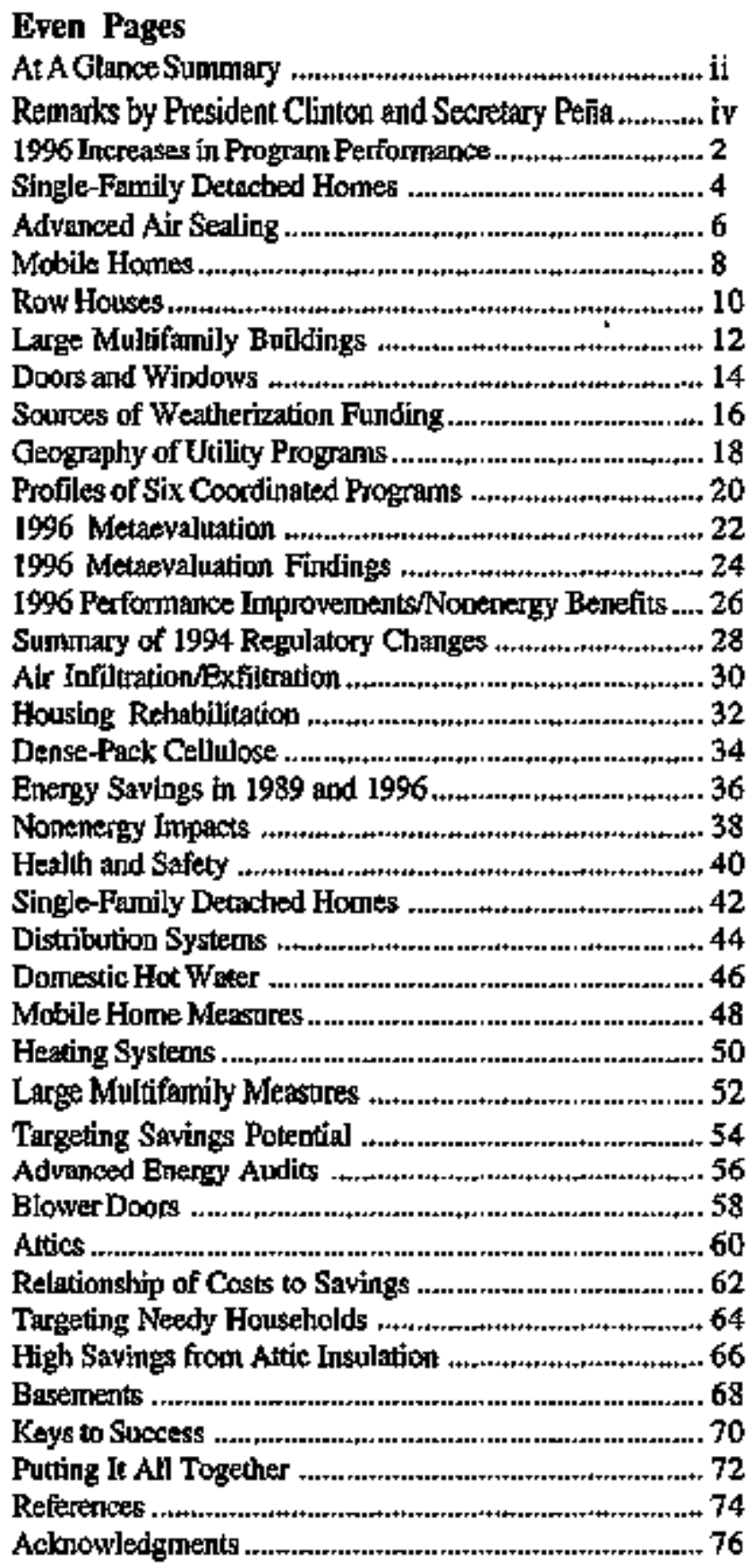
Odd Pages
I Overview ................................................................ 1
II Program History ...................................................5
III. The Scope of Weatherization …............................7
A. Types of Measures Used ..................................7
Measures for Mobile Homes ...........................9
Measures for Row Housts ...............................11
Measures for Large Builditigs ...........+.+............ 11
B. Sources of Funds ............................................. 15
C. Uses of Funds: DOE Sets the Pace .................... 19
D. Utility Partnerships.........................................19

IV. Metaevaluation Methods and Results for 1996 ......23
A. Three Methods Show Trend Toward
Higher Savings
B. Reasons for Increases in Program
Savings .
C. Nonenergy Benefits of Weatherization...........,27
D. Cost-Effectiveness Results ............................29
E. Conclusions from the 1996
Metaevaluation

v. National Evaluation Methods and Resulis for 1989

A. National Evaluation Process and

Publications. 33

B. Diversity of Dwellings and Agencies ................35

C. Program Benefits ..............................................37

National Exergy Savings in 1989 ....................37

Nonenergy Benefits .........................................39

D. Cost Effectiveness ............................................43

Program Costs ................................................ 43

National Cost Effectiveness .............................. 45

E Performance by Climate Region in 1989 ..........47

The Cold Climate Region ,..............................49

The Moderate Climate Region ........................51

The Warn Clinate Region...............+..............53

VI. Response to Evaluation Findings .............+.............55

A. Savings Associated With Specifie

B. Promising Management Practices ...................59

C. The Warm Clinate Weatherization

Initiative

VII Remaiging Opportugíties ....................................63

A Additional Investments per Home ...............+.+63

B. Targeting the Neediest Households ...+1+...........65

vII. The Future of Weatherization: The Next Steps ..... 67

A. Service Delivery Procedures .........................67 67

B. Weatberization Measures ,................................69

IX. Cone[usions ........................................................7]

Significant Findings .................................................73 
"thave seen first hand how many jobs weatherization progranss create and also how much good they can do ... A lot of this weatherization wodk for poor people, especially for a lot of elderly people who are stuck in these old houses that have holes in the walls ... or in the floor, not only makes them warmer in the winter and cooler in the summer, they also save money on their utility bills. [Weatherization] conserves energy and puts more money in the pockets of people who have just barely enough to get by. So I strongly support [weatherization prograns] ... It's a kind of hard sell in the Congress now because the price of oil is so low and energy is so cheap--it's much cheaper in America than it is in any ofher major country. But if you just have enough to get by on, [if] you're living on a Social Security check or you're living on a minimum wage, [utility bills] are stil] very, very expensive and a big part of your budget."

President Clinton's remarks concerning the Department of Energy's Weatherization Assistance Program at the Summer of Seryice Forum held at the University of Maryland, August 31, 1999.

"By implementing energy-saving measures in low-income homes, the Weatherization Program works to conect the disproportionate energy burden faced by low-income Americans who often face the difficult choice between buying food or fuel. Consequently, weatherization helps low-income resider:s gain financial independence, thus offering a hand-up not a hand-out."

Excerpt from Secretary Peña's testimony before the Senate Commitfee on Bnergy and Natural Resources, May 13, 1997. 


\section{Progress Report of the National Weatherization Assistance Program}

\section{OVERVIEW}

The U.S. Department of Bnergy's (DOE) Weatherization Assistance Program (the Program) bas long served as the nation's core program for delivering energy conservation services to low-incone Americans. The Program reduces the heating and cooling costs for low-income families - particularly the elderly, persons with disabilities, and children $\rightarrow$ by improving the energy efficiency of their homes and ensuring their health and safety. In combination with closely related programs sponsored by the Department of Health and Human Services (HHS) and supplemental funding from other sources, the DOE Weatherization network is operated by state entities in all 50 states and is managed by the DOE Office of State and Community Programs (OSCP). This network has weatherized more than four and one-half million households since its inception in 1976 .

In 1990, DOE sponsored a comprehensive evaluation and assessment (the National Evaluation) of the Weatherization Progran under the supervision of Oak Ridge National Laboratory (ORNL). The National Evaluation concluded that the Program meets the objectives of its enabling legislation and fulfils its mission statement. Specifically, it

- saves energy,

- lowers fuel bills, and

- improves the health and safety of dwellings occupied by low-income people.

In addition the National Evaluation concluded that, based on 1989 data, the Program bas been achieving its mission in a cost-effective manner, with benefits exceeding costs acconding to all three standards employed by the evaluators. Annual savings for households beated with natural gas, the predominant home heating fuel, were estimated to average $17.3 \mathrm{Mbtu}$ per weatherized dwelling. This constituted a rectuction of 18.3 pexcent in natural gas consumption for space heating, or a 13.0 percent reduction in natural gas consumption for all end uses. The National Evaluation also pointed to several promising approaches and practices that could further improve the overall performance of the Program in fuhre years.

A 1996 Metaevaluation of 17 state-level evaluations (the Metaevaluation) suggested that improved practices have indeed produced 80 percent higher average energy saving per dwelling today as compared to the measured savings in 1989. The Metaevaluation, which developed a regression-based national estimate of savings, indicated that average savings in homes using natural gas as the ptimary heating fuet were $312 \mathrm{Mbtu}$, which was 33.5 percent of natural gas space heating consumption. The savings constituted a reduction of 23.4 percent in consumption of natural gas for all end uses. 


\section{INCREASES IN PROGRAM PERFORMANCE}

The Metaevaluation in 1996 showed an $80 \%$ increase in energy savings, greater reductions in $\mathrm{CO}_{2}$ emissions, and increased cost effectiveness since 1989


Cost-Effectheness Restits for Gas-Beated Homes:

Benefit'Cost Ratios' from Three Perspectives in 1989 and 1996

\begin{tabular}{|l|ccc|}
\hline & Program & Installation & Societsal \\
\hline National Evaluation 1989 & 1.06 & 1.58 & 1.61 \\
Metaevaluation Results 1996 & 1.79 & 2.39 & 2.40 \\
\hline
\end{tabular}

See page 29 for an explanation of the calculation procedmes and a definition of the diree perspectiveg. 
With the incteased energy savings, the value of annoal avoided energy costs per gas-heated household also increased from an average of $\$ 107$ to $\$ 193$, and the benefiticost ratio for the Program rose from 1.61 to 2.40 .

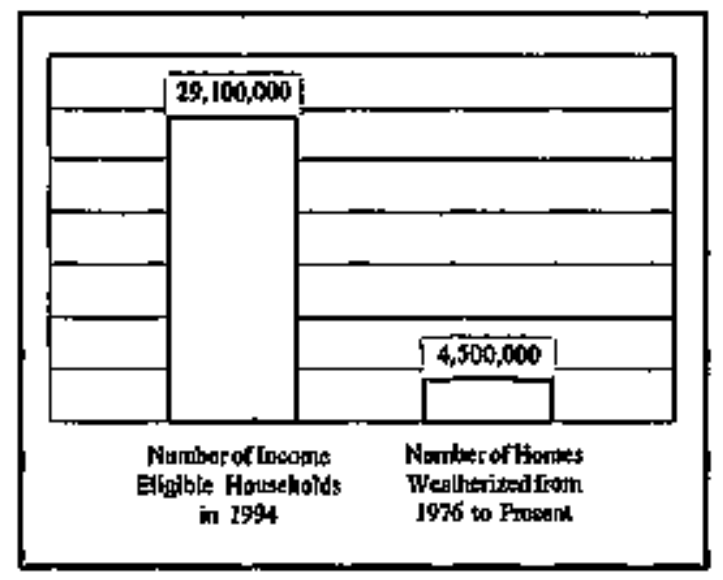

Although the Weatherization Progran has successfully accomplished a significant portion of its mission, additional activities need to be undextaken to meet the ongoing need for low-income weatherization. The Departrnent of Health and Human Services has reported that, based on Energy Information Administration data, there were 29.1 million bouseholds with incomes near or below the federal poverty guidelines for Weatherization eligibility in 1994. These households were spending an average of 14.9 percent of income for xesidential energy. This compares to an average expenditure of 3.6 percent of income for residential energy by non-lowincome households. The mast tecent Residential Energy Consumption Survey indicates that 1.5 million households experienced heating interruptions becanse of their financial situations during one year.

From Progran Year (PY) 1985 through PY 1995, the Program's network of 1,100 local agencies weatherized an average of 200,000 dwellings per year. Substantial bndget reductions for Weatherization Assistance in PY 1996 and PY 1997 have forced a reduction in the number of agencies performing weatherization and have cut the number of dwellings weatherized to approximately 70,000 annually. This downsizing is the most tecent challenge to carrying out the Program's mission in an efficient and effective manner.
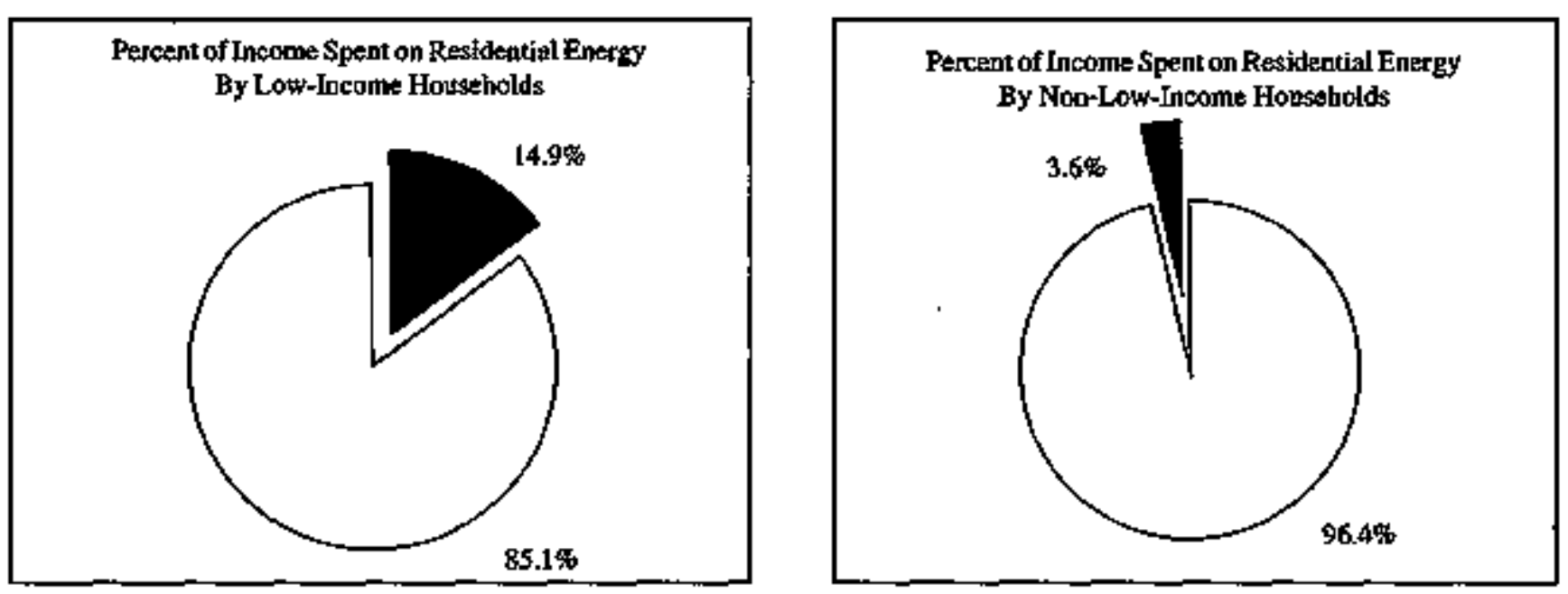


\section{SINGLE-FAMIILY DETACHED HOMES}

This series of photographs itlustrates the age and diversity of single-family homes weatherized by the Program.

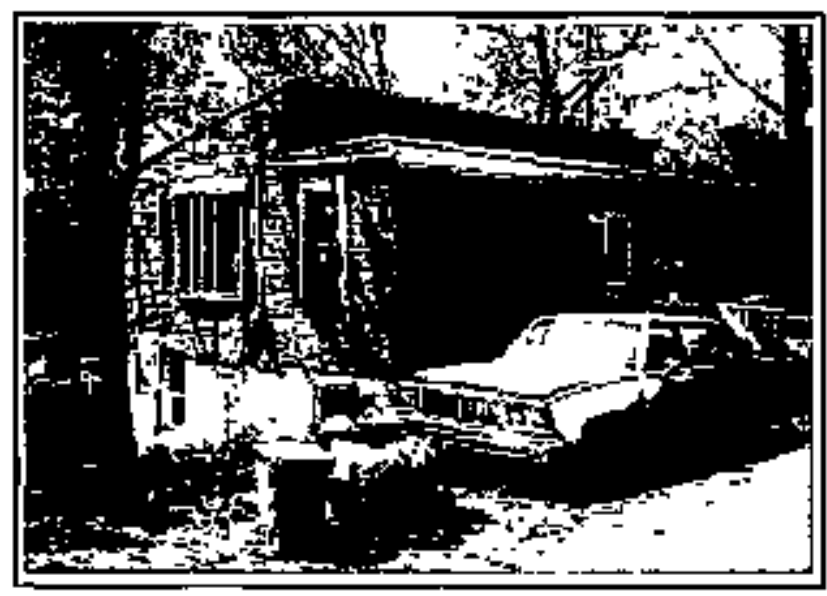

The weatherization job on this house will include foundation wall repair.

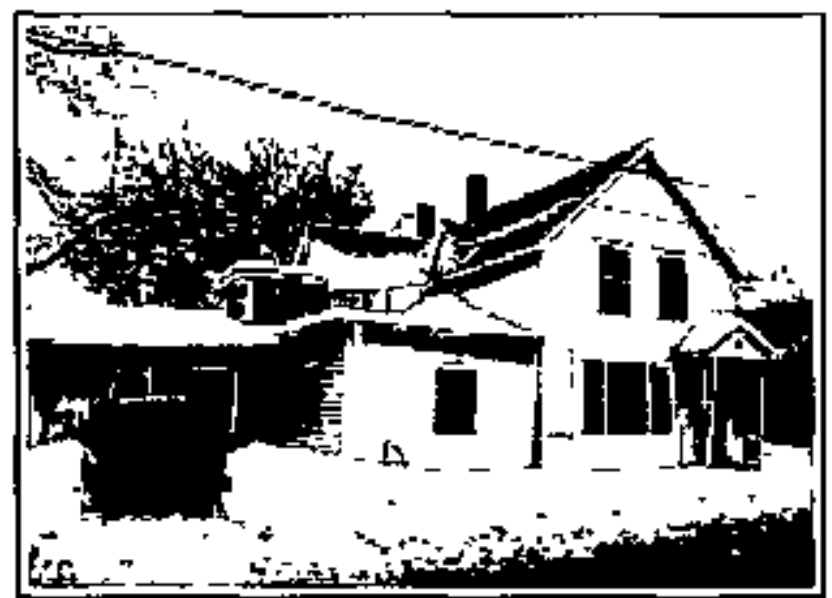

Patterns of snow and ice indicate a leaks, poorly insulated attic.

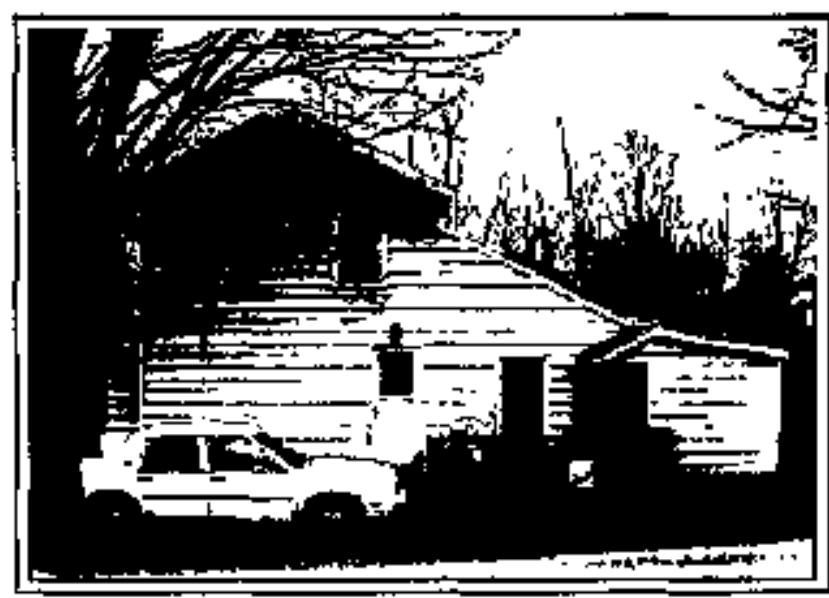

This roofline suggests complex paths tor alr leakage.

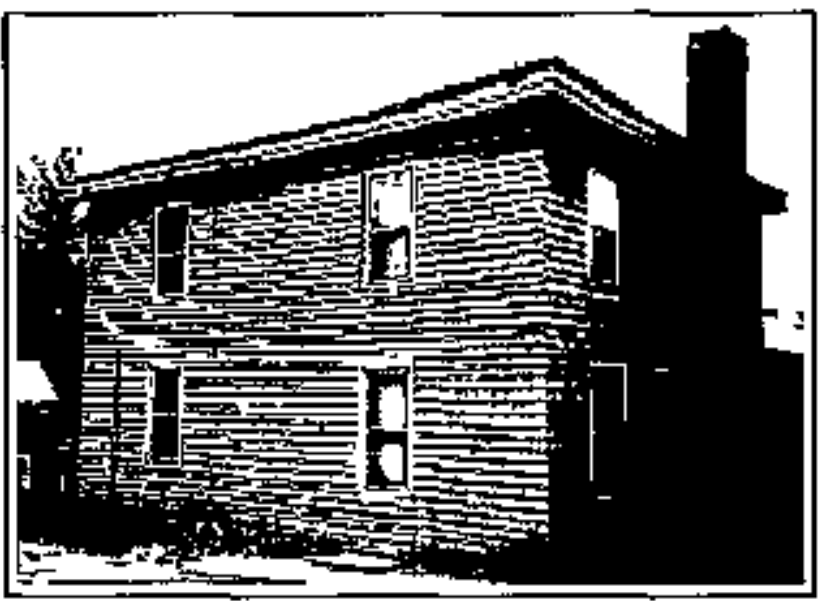

A good candidate for wall manalation.

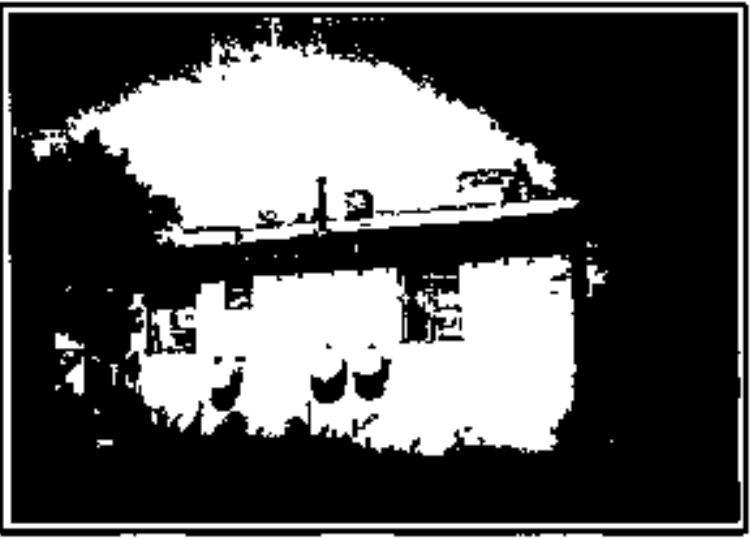

This concrete biock house is typical of hones that are westherfzed in rural Georgia. 


\section{PROGRAM HISTORY}

Most Americans were dranatically affected by the 1973 oil crists. Huge home heating bills were a heavy burden on some household budgets, sinking many farnilies into debt. Low-income families in cold climate states, who received high heating bills, suffered the most severe consequences. In Maine, where nine out of ten homes are heated with oil, state officials and community action agencies worked with homeowners and renters to seal bouse leaks (where costly heated air poured out and

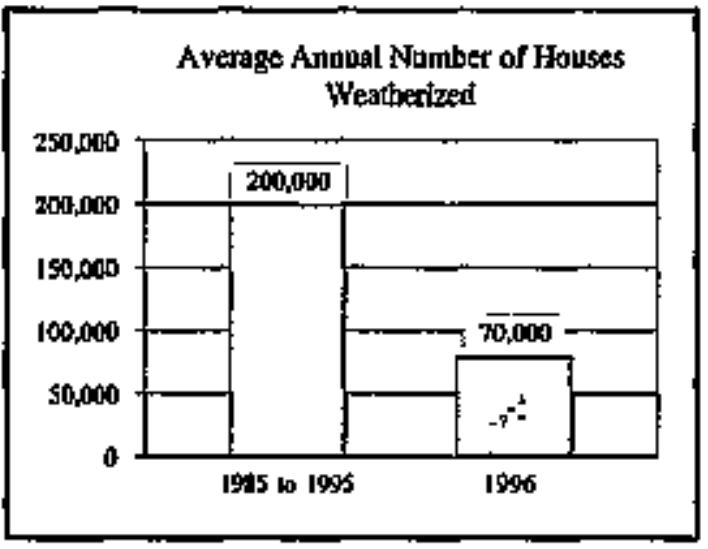

Average Annual DOE Budget

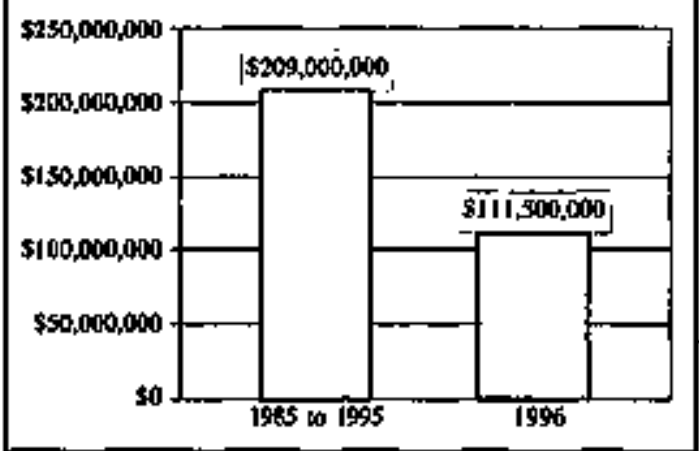

cold air entered). Retrofititing clut bills and saved oil. Out of this effort, the Nation's first weatherization program was bom. Congress created the DOE's Weatherization Assistance Program in 1976 under Title IV of the Energy Conservation and Production Act.

The Program initially emphasized emergency and temporary measures, including caulking and weatherstripping of windows and doors, and low-cost measures such as covering windows with plastic sheets. By the early 1980 's, the emphasis had tumed to more permanent and more cost-effective measures, such as installing stom windows and doors and insulating attics. In 1984, regulations were passed to allow Weatherization Assistance funds to be spent on space and water heating system efficiency changes. In 1985, spending for the replacement of defective furnaces and boilers was approved.

In the 1990's, the trend toward emphasizing more costeffective measures continured with the development and widespread adoption of advanced audits. Advanced audits are now used in 37 states. By 1996, the Program's performance had improved significantly because of the implementation of many of the recommendations of the National Evaluation and of other DOE-sponsored research. In spite of funding reductions, technical advances produced 80 percent higher energy savings per dwelling. Increases in exergy savings were achieved throngh better training, audit tools, and management practices with little increase in cost.

Among the new DOE regulations implemented in 1994 were changes that promote the use of advanced audits, and that permit the use of cooling efficiency measures such as air conditioner replacements, ventilation equipment, and screening and shading devices. In warm climates, where cooling costs may be higher than heating costs, cooling measures can now be installed when appropriate. Barriers to performing work on heating systems and mechanical equipment have also been removed. The requirement that 40 percent of Program funds be spent on materials is waived in states that adopt approved advanced audits, thus ensuring audit-driven cost-effectiveness tests of investments. With increased flexibility, better messure selection procedures, and more advanced diagnostics (such as blower-doof directed air sealing), the Program now instalis more cost-effective combinations of measures tailored to the needs of particular dwellings and clinates. 


\section{ADVANCED AIR SEALING}

In the last several years, it has been shown that sone previously ignored areas of dwellings can be potent sources of convective losses. If such losses are found and treated, they offer high potential for savings. As illustrated in the figmes, these include interstices between floors, spaces between the conditioned envelope and such buffer zones as porches and garages, and areas between old and new portions of dwellings. The blower door, in conjunction with a gauge that measures differences in pressure, is a valuable tool in identifying leakage to or from these areas, helping both in identifying the magnitude of the leakage and in verifying when such measures as the blowing of high-density cellulose or otien air-sealing measures will solve the problent, Weatherization agencies that integrate these tests and tactics into routine operations achieve excellent sayings.

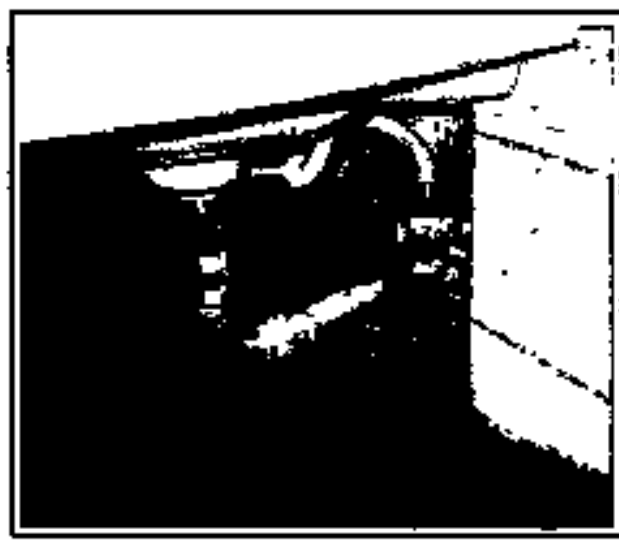

Note the infiltration ares onder the bathroom sink, which conmects to the attic wia a stud cavtty in an interior wall.

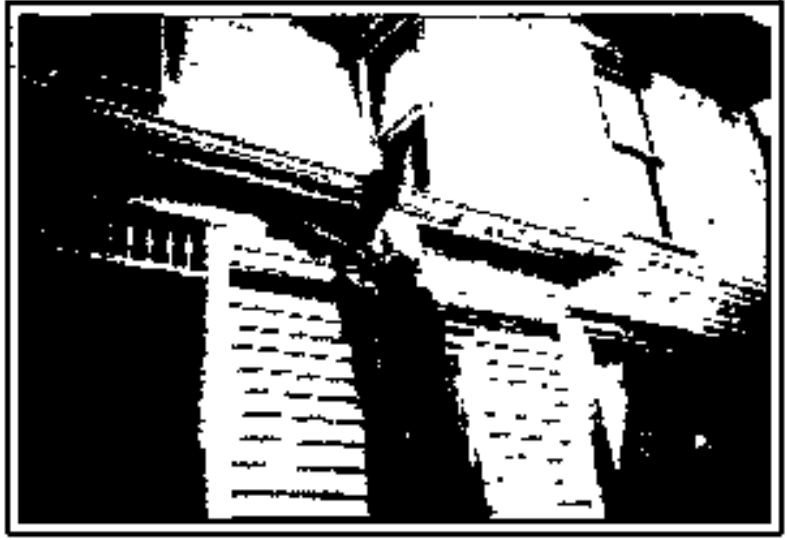

As revealed by a blower door and a pressare gauge in a test that takes only several minutes, the area under this porch is directly connected to the envelope throoigh floor joists between the first and second floor. Hif gh-density insulation is being used to air seal this largest hole in the dwelling.

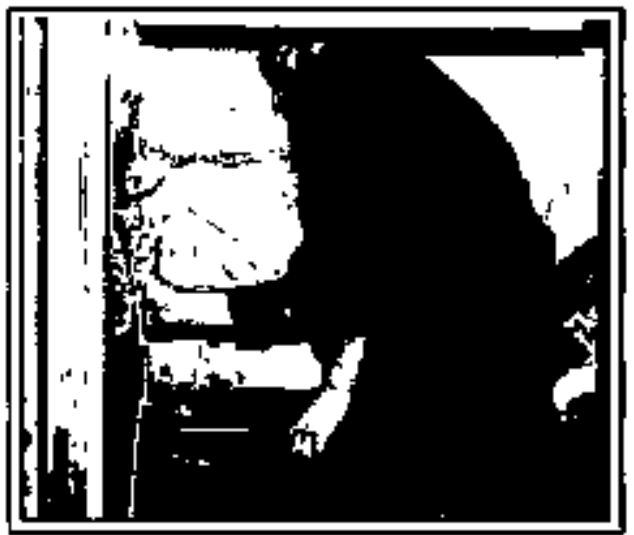

Air sealing a plombling chase on the first flore that corresponds with hoth attic and baserment. Sealing holes in inconspicions and hard-to-get-to places are frequently those which resaltin gond, cost-effective weatherization jobs.

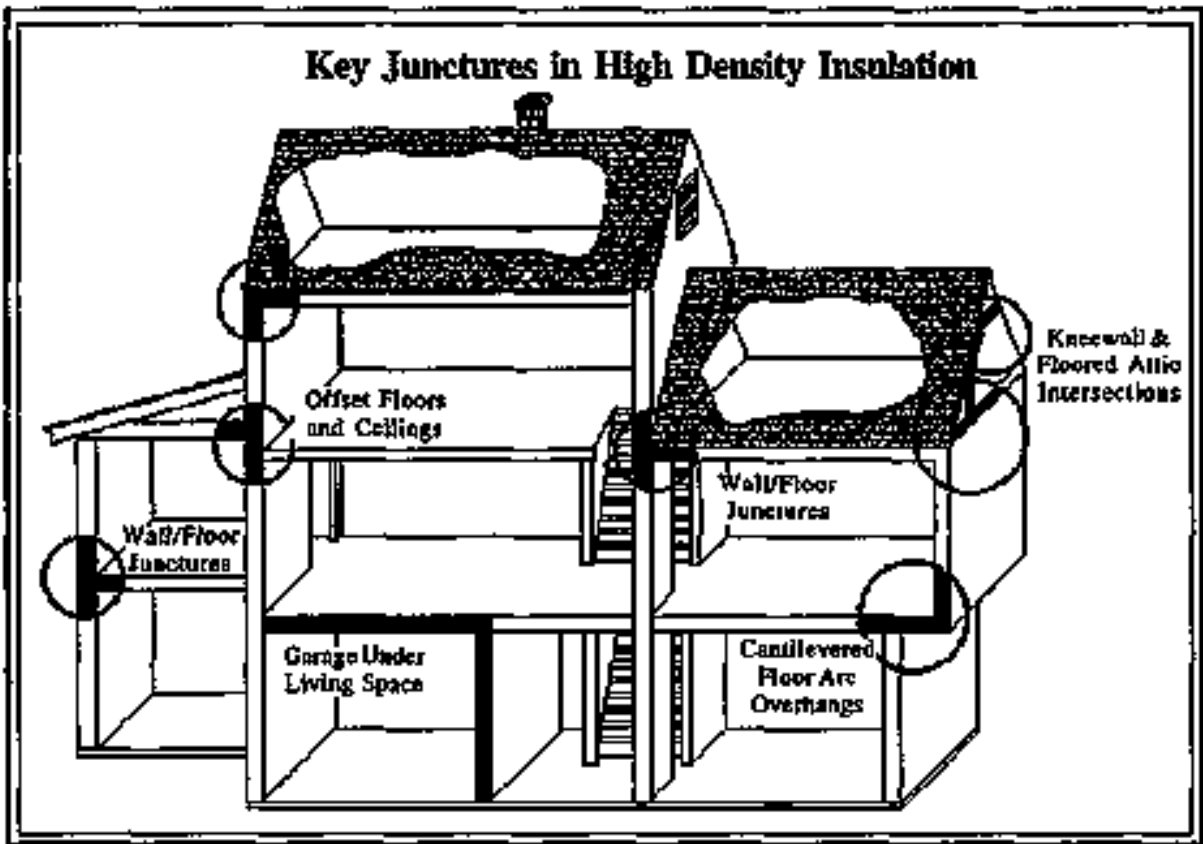




\section{THE SCOPE OF WEATHERIZATION}

\section{A. Types of Measures Used}

A variety of weatherization measures are used by DOE's Weatherization Progtam to improve the energy efficiency of dwellings occupied by low-income people. Although audit methods to optimize the type and amount of weatherization measures have improved, the set of measures that is typically considered has remained relatively constant between 1989 and 1996. Detailed resuls from the National Evaluation indicated that the following measures were those most commonly used in 1989;

Air leakage control was the most common type of weatherization mensure installed in single-family and smalt multifamily dwellings. General caulking and weatherstripping around windows and doors were by far the most common of these measures at the time of the National

Advanced Audits Select More Insulations, FewerStorm Windows

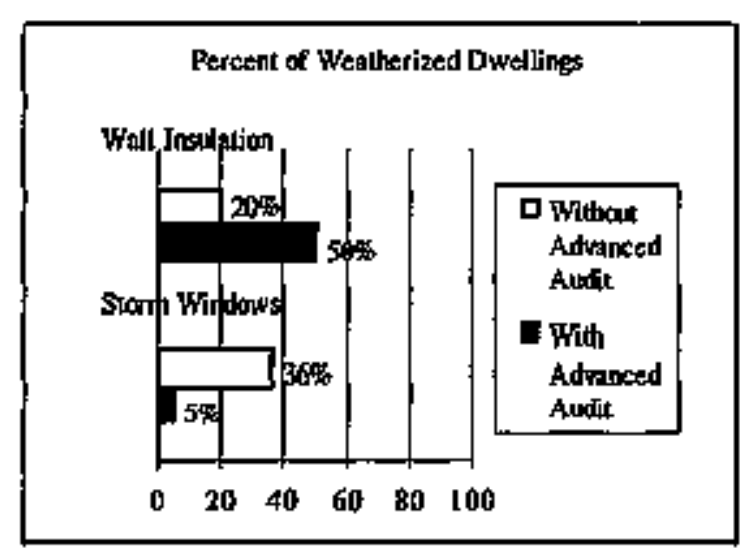

Evaluation. Today, blower-door directed air sealing and air leakage control measures for distribution systems are used frequently. These techniques reduce air leakage much more effectively.

Insulation was the next most common type of energy conservation measure installed. Attic insulation was either used for the first time or added to existing insulation in the majority of homes receiving insalation. Wall insulation was installed in less than 20 percent of homes. Today, with the use of advanced audits, attic and, especially, wall insulation are installed much more frequently.

Energy-efficiency improwements to water heater systems were made in 56 percent of the weatherized homes in 1989 . Most of these retrofits involved tank or pipe insulation. Today an even larger majority of homes receive water heater measures. In addition, water temperatures are reduced and low-flow showerheads are added in a higher percentage of homes.

Energy-efficiency improvements to windows and doors occurred in 42 percent of homes weatherized at the time of the National Evaluation. Additional window and door work was conducted primarily for repair purposes. By far, the majority of these improvements involved the addition of storm windows (36 percent) or the replacement of entire windows ( 37 percent). Advanced audits are unlikely to reconmend storm windows or window or door réplacements in most homes. Therefore, these measures are installed less frequently today.

Nearly one-thitd ( 30 percent) of the homes weatherized had energy-efficiency improvements made to their space heating systems. Most of these improvements involved tune-ups, during which heating systems were cleaned, controls adjusted, and filters replaced. Incrased attention to space heating measures probably characterizes the Program 
MOBILE HOMES

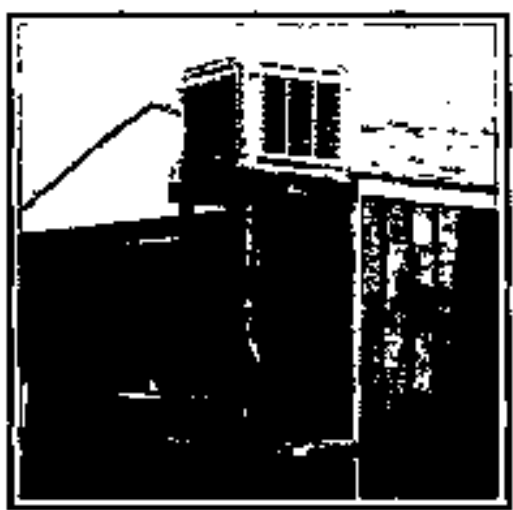

Evaporative chillers (swamp coolers) often mean large leaks.
Due to the exonomic realities of affordable bousing, many low-income families live in mobile homes.

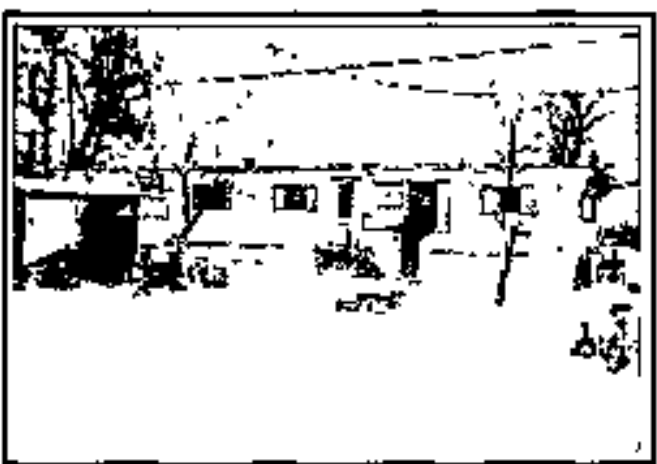

This home used over $\$ 1,000$ of fuet oil per heating season before weatierization tightened it op and installed a more efficient oll burner.

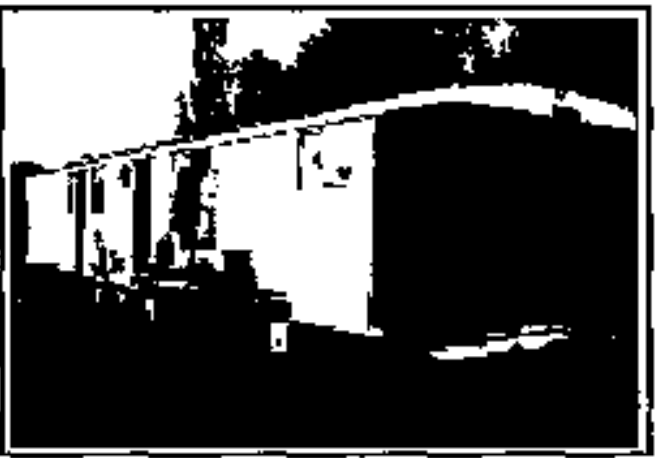

Mobile homes with poar foundations often develop major stractural problents.

enercy, but air sealine ducts in mobjile homes are nsually a more costreffective retrofft.

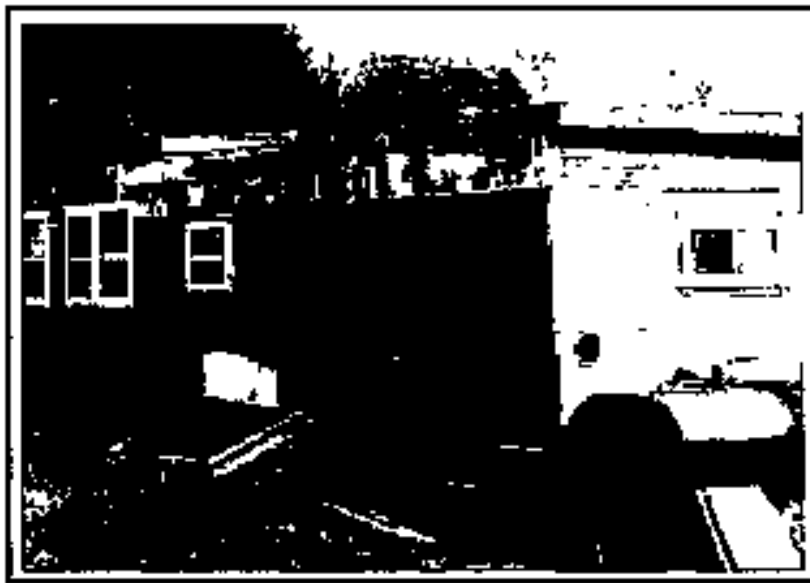

Very poor inswlation causes major problems with mobjle homes bult before HUD's energy standards were adopted in 1976 .

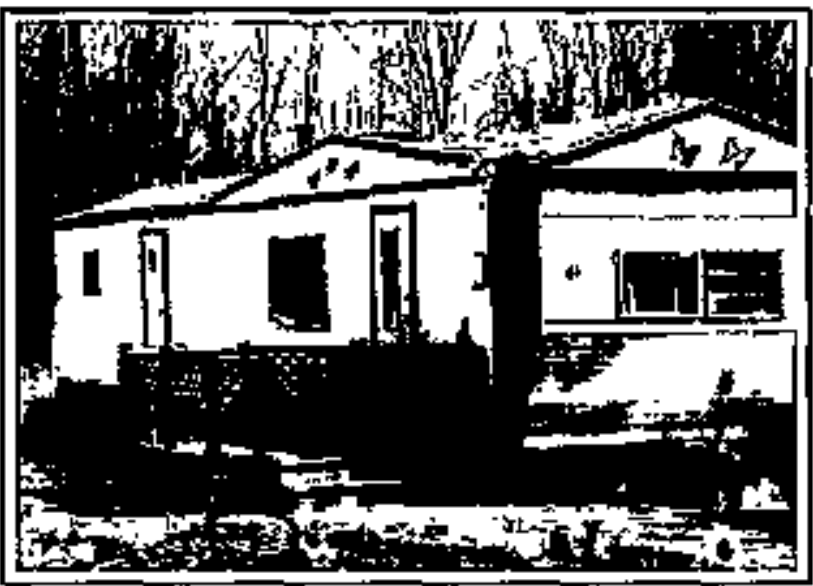

Skirting onder a mobile home is not as important for the heating bill as belly board insulation, which can be blown in by weatherization crews. 
coday because barriers to performing work on heating systems and mechamical equipment have been removed. Distribution systems also now receive increased attention for both heating and cooling applications. In addition, new regulations implemented in 1994 allow for the use of cooling effleiency measures including air conditioner replacentent, ventilation equipment, and screening and shading devices. These measures enable the Program to more effectively address the energy efficiency needs of homes in warm climates.

The requirement that 40 percent of Program funds be spent on materials is wajved in the 37 states that have adopted approved audits, thus ensuring that the most cost-effective package of investments will be selected. These and other Program updates allow increased flexibility to select the most appropriate measures for specific dwellings in particular regions.

\section{Measures for Mobile Homes}

There are seven million "manufactured homes" in the United

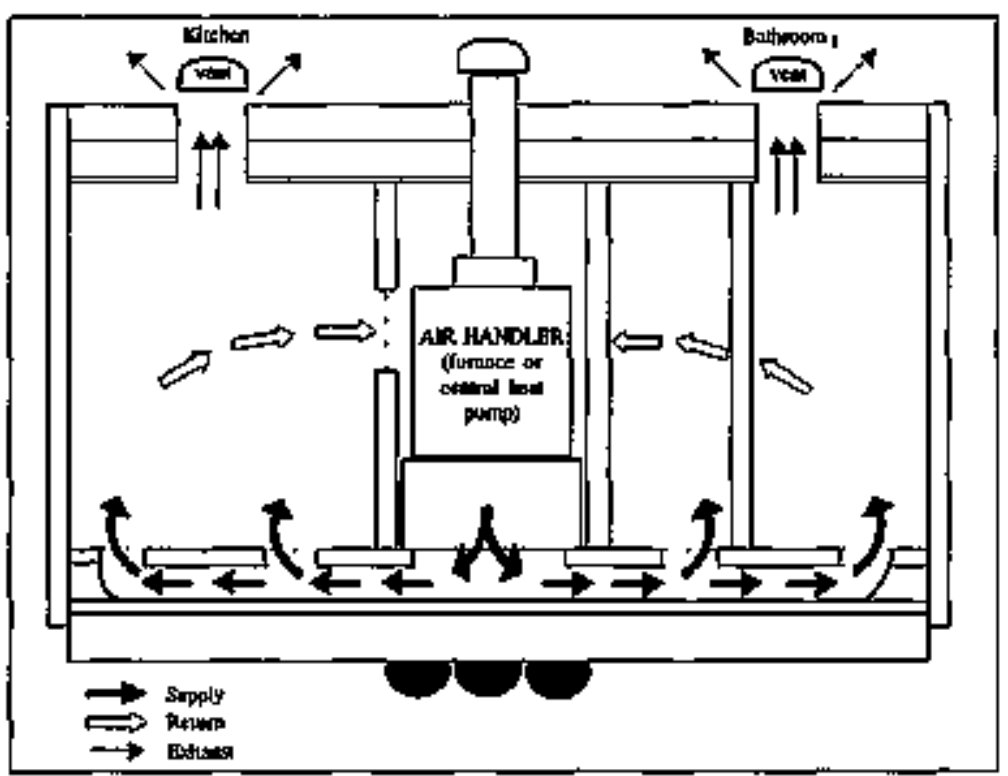
Stares and the number is growing. Well over half were constructed before 1976, when HUD initiated its mandatory national standards on manufactured home construction. These older units, which tend to be occupied by lower-income people, suffer from a variety of ills. Energy problems stem from shoddy construction, improper site set ups, and poor maintenance. As a result, many are leaky, uncomfortable, and have high energy bills.

The profile of weatherization measures installed in mobile homes differed from that of other housing types. In 1989, mobile homes were much less likely to receive any type of insulation than the average home ( $20 \%$ vs. $62 \%$ ), and nearly all mobile home insulation consisted of floor insulation. Blowing the space between

Moblle Home Heating System Distribution System the belly board and the floor of older mobile homes with instulation, is combination with attention to air sealing and duct leakage, solves many conductive and convective problems so that less heat is wasted.

Blower-door-assisted air sealing is becoming a more prominent part of mobile kome weatherization. Quite frequently, major leaks are found in unobvious places, such as main electrical boxes, plumbing chases, and ducts. The combingtion of leaks in mobile home ducts and belly boatds nesults not only in low heating and cooling efficiency, but also in uncontrolled air leakage. This wastes energy and can affect indoor air quality, raise moisture levels, and cause structural deterioration.

In 1989, water hearing measures were installed less frequently ( $48 \%$ vs. $56 \%$ ) in mobile homes than in other types of structures, while window and door measures ( $50 \%$ vs. $42 \%$ ) were installed more frequently. Installation of inside stom windows covering leaicy jalousie-type win- 
Although most dwellings weatherized are single-family detached structures, other dwelling types are also common.

\section{ROW HOUSES (SINGLE-FAMITY ATTACHED DWELLINGS)}

Row houses, which predominate in many older American cities in the Northeast, can be extremely wasteful of energy. Leaky flat roofs cause falling ceilings and massive air leakage.
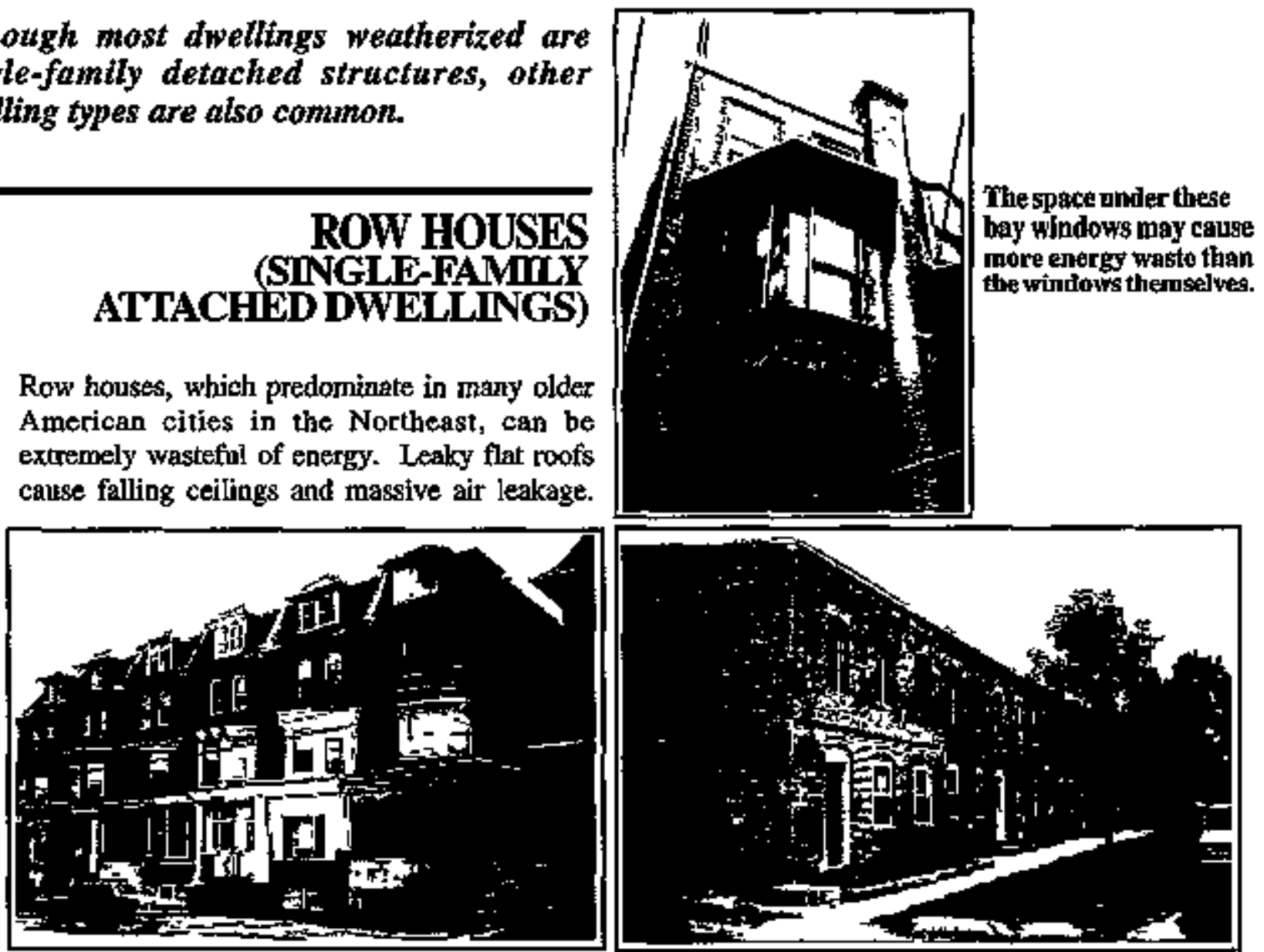

The space above porch ceilines is often connected to the inside of the front wall.

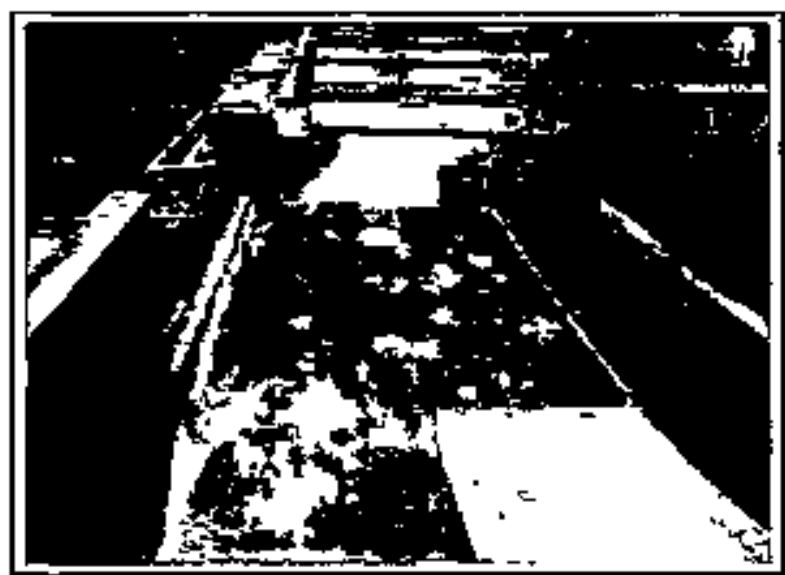

Leaky roofs pose big problems.

A solid extexior may conceal Inner decay.

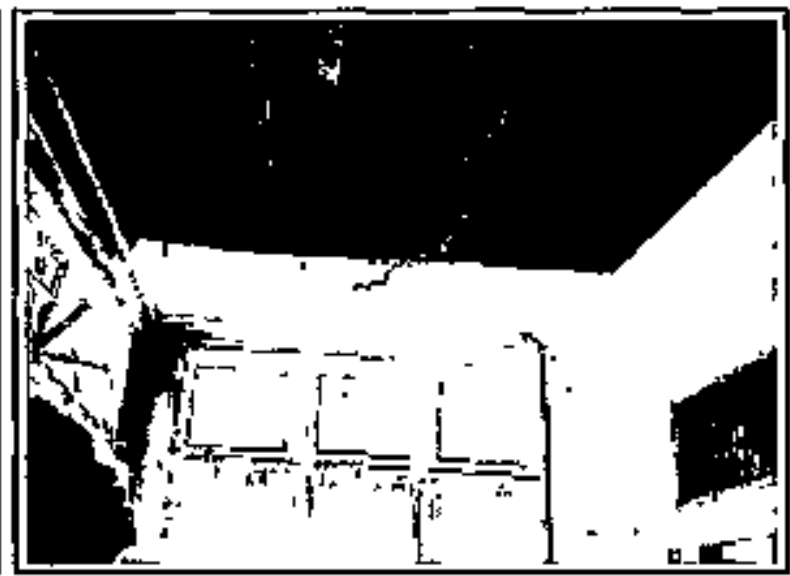

The conseguences of murepatred roof leaks.

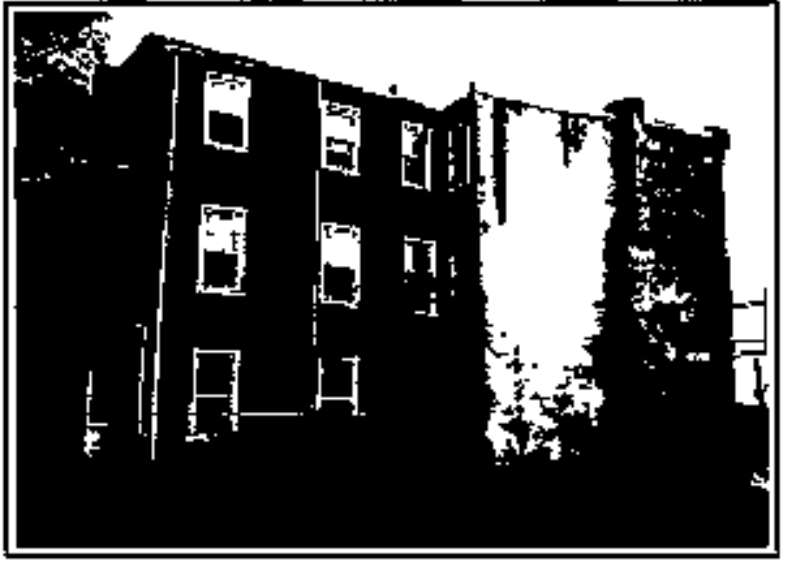

Newly nissing nextdoor netghbar causes major air infiltration. 
Weatherized Row Houses and Mobile Homes Are Concentrated in the Moderate Climate Region dows was especially common in mobile homes. Most mobile homes received one or more measures that were especially suitable for this type of dwelling, including underpinning, skitting, cool seals on the roof, and belly board insulation.
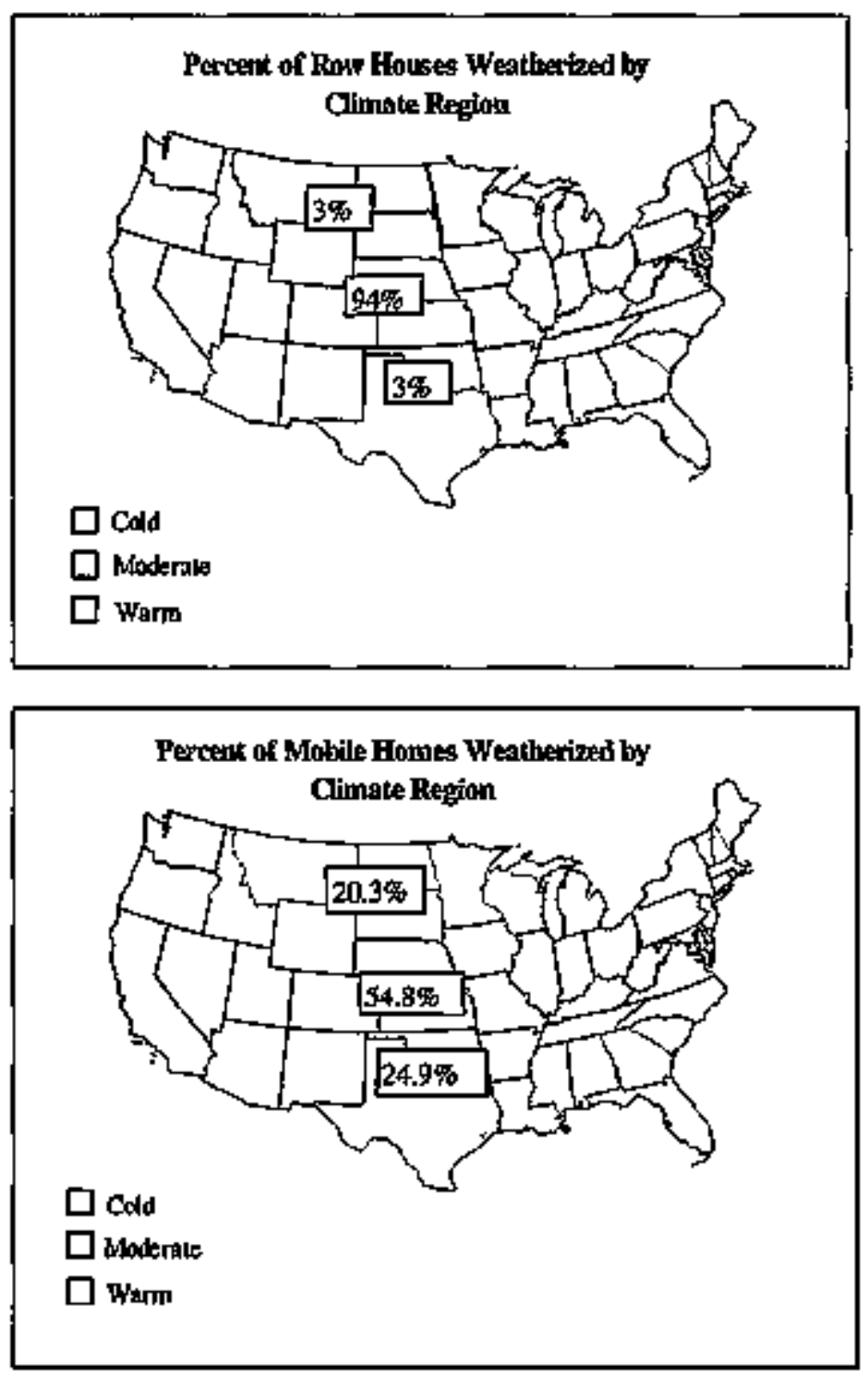

An audit designed specifically for mobile homes is being developed for the Program's use. This advanced audit will improve the auditor's ability to select the most costeffective packages of measures for mobile homes.

\section{Measures for Row Houses}

Row houses tend to be among the most wasteful and leaky housing stock in the country. Accordingly, extensive air sealing measures were undertaken on virtually all weatherization jobs performed in 1989. The work is complicated in that some air leakgge may be conditioned air from an adjoining house, a fact that affects both energy use and indoor air quality. In addition, part of the inberent architectaral charm of row houses, including such details as porches and bay wirdows, can mask subtle convective and conductive problens. Thus, air sealing these tames requires special care and sealing techniques.

In 1989, "first time" attic insulation was installed at higher rates in row houses than in any other type of housing, pointing out their poor thermal condition. In addition, roof repairs were used more frequently for row houses than for other housing types. A major source of energy waste in older row houses occurs when their flat roofs leak water, ultimately causing ceilings to fall. This allows stackeffect infiltration to have devastating effects on the fuel bill. As explained on page 30, stack-effect infiltration results from the rising of warm air in the interior, pulling in air at the bottom of the conditioned envelope and exhausting warm air at the top. Pressure differences at the top and bottom are at their maximums, which makes holes in these areas critical to repair.

\section{Measures for Large Buildings}

The weatherization of large multifanily buildings, those with five or more units, presents local agencies with chalienges different from those presented by smaller dwellings. Most of the work is accomplisted in distressed urban areas where both buildings and much of the surrounding communities suffer from maintenance problems and even abandonment. Consequently, facade facelifts in the form of window repair and replace- 


\section{LARGE MULTIFAMILY BUILDINGS}
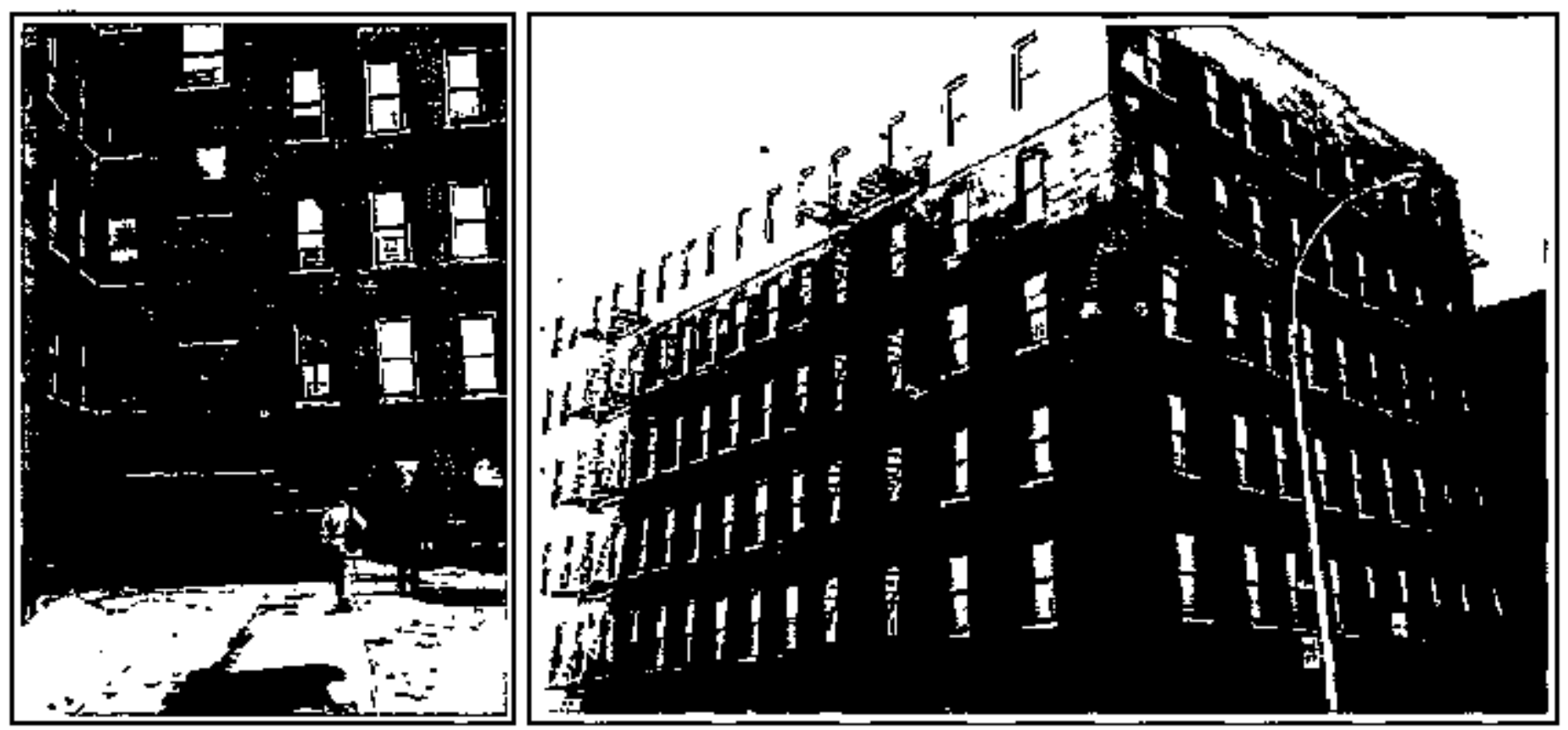

This large building in the Bromx was almost ready for abandonment when weatherization played a key role in its restoration.

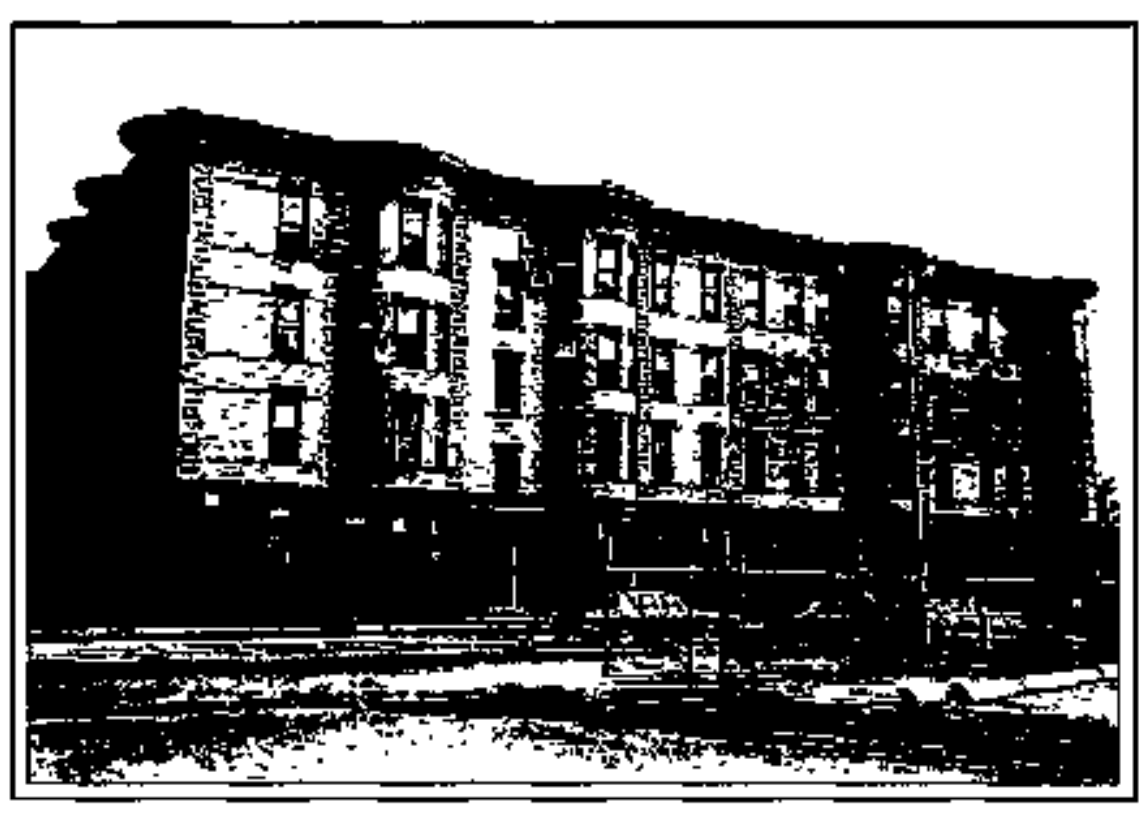

This is a large multifamily dwelling in Holyoke, Massactnusetts, which was weatherized by HAP Inc, from Spriugfield, Massachusetts.

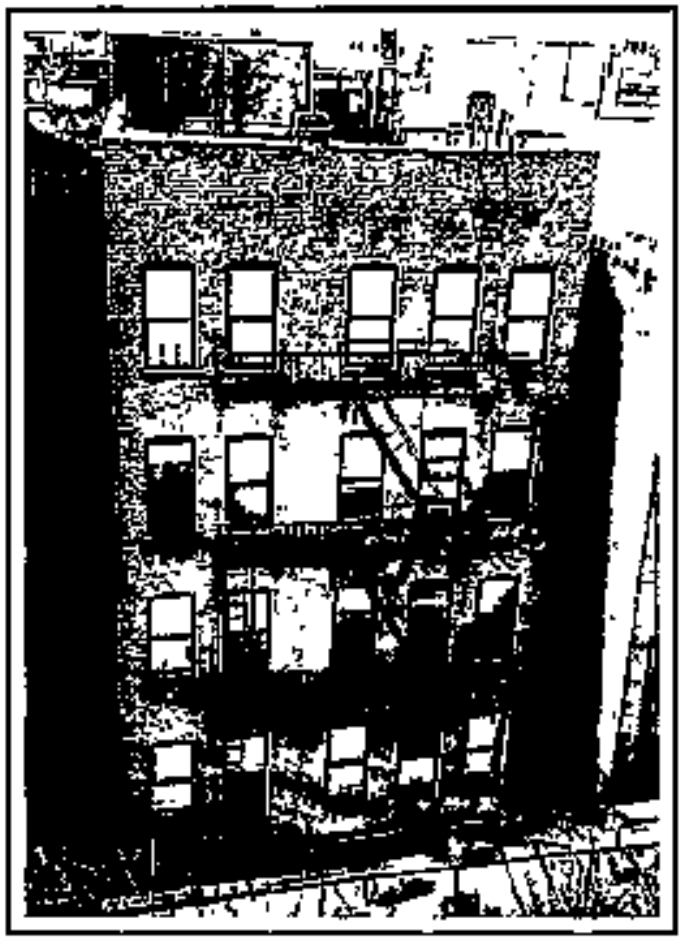

This is the back of a four-story building in Brookdyn. After air sealing, hoiler, and window replacements, the energy expendihures for this bullding are approximately 40 percent less than the prevlous year's fuei expenditures. 
ment has been the focal point of most large multifamily operations, accounting for 80 percent of material expenditures in Program Year 1989 in which 20,000 units in multifamily buildings were weatherized (MacDonald, 1993). In rental units, which dominate in multifamily buildings, local agencies have special safeguards in place to ensure that energy saving benefits are passed along to the tenant. In addition, a significant Jandlord finarcial contribution to the project is often required.

The diversity of housing stock and approaches to weatherization found in single-family housing also holds trie in the multifarnily sector, where the uniogue features of the urban environment requice especially creative responses. This diversity is illustrated by findings from three case studies summarized below (Kinney et al., 1994).

S0 Percent of Moltifamily Weatherizations Take Place in New York and the Rest in Other Large Cities

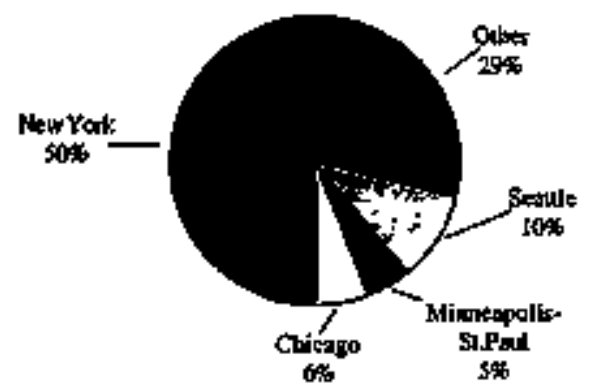

The New York City weatherization operation, with its 22 local agencies, accomplishes over half of the multifamily weatherization work done nationally by the Weatherization Program. The need for such services is apparent. New York City has 126,000 multifamily buildings with more than 1.9 million apartments. An average apartment uses over 865 gallons of fuel oil (or its equivalent) annually for heat and domestic warm water, a startlingly large number for the climate and average apartment size. This inefficiency makes muldifamily buildings very good targets for cost-effective conservation retrofits.

The trend in current multifanily weatherizaMultitamily Weatherization Takes Place in Large Cities tion operations in New York City is to concentrate on the heart of the building, the boiler room, and on its arteries, the distribution system. Poorly designed, controlled, and maintained heating systems are a major culprit in causing some bujldings to consume five to six times as mach energy as their neighbors. In response, professional energy auditors using state-of-the-art testing equipment and EA-QUIP anaiytical software undertake building audits that result in detailed work orders. These include computations of costs and benefits of all retrofit measures anticipated and specifrcations of each element of the proposed work. These work orders, most of which are accomplished by the staff of the New York City Weatherization Coalition, are instrumental both in ensuring that resulting weatherization work meets rigorous standards and in leveraging funding from building owners.

In Chicago, the City government administers the Weatherization Program, serving single-family, smaller, privately owned multifamily buildings (typically three and four story wakk-ups), and larger public housing projects managed by the Chicago Housing Authority. Because of the Prograrn's excellent reputation for quality performance, a waiting list of over one year for weatherization services has resulted. Buildings on the waiting list are served on a first-come, first-served basis.

Past weatherization measures were concentrated at the apartment leveI with strong emphasis on storm and replacement wikdows. 


\section{DOORS AND WINDOWS}

Although most dwellings recuire air sealing, insulation, furnace retrofits, and at least minor repair work, exactly which tactios to employ is a decision that depends on the circumstances of the dwelling, the funding of the agency, and the know-how of the auditor and crews. The National Evaluation, plus testimony from experienced practitioners in the field, has stown that cookbook procedures employed in the early days of the Program-weatherstripping, caulking, and storm windows-were only marginally effective. Audits using advanced diagnostics direct crews to the real problems in a dwelling and usually result in more cost-effective work.

Window and door repair is a necessary part of most weatherization operations, but many agencies bave abandoned the practice of routinely installing storm windows and exterior doors because they have found these measures do not save as much as many other less costly conservation measures.

Althoughthids storm vindow is still functional, missing window trim and a rotten sill plate have dane substantial damage. The sash weight is visible from the ontside of this dwelling.

When window frames are ont of square in an older home-usually due to foumdation problents-sine agencies try to repair the primary window and instal new storm windows.

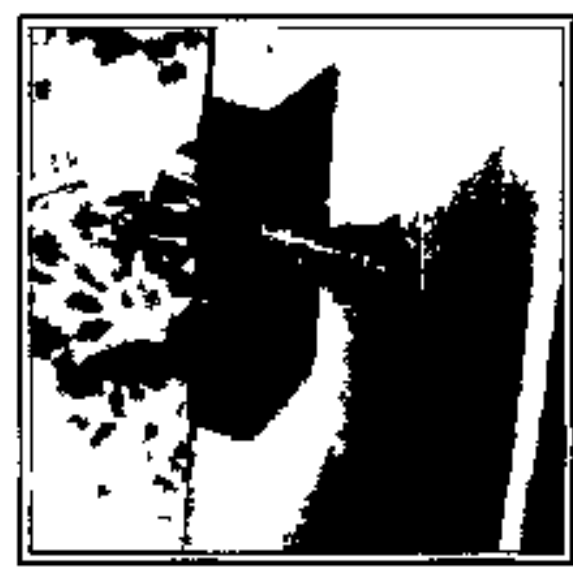

A new Jock set ts only marginally cost effective as a weatherization measure (it can aid in air sealing), but since it supplies a measure of security, this repair can be the most ilimortant one for a client. Sometimes a new door performs a similar secarity function.
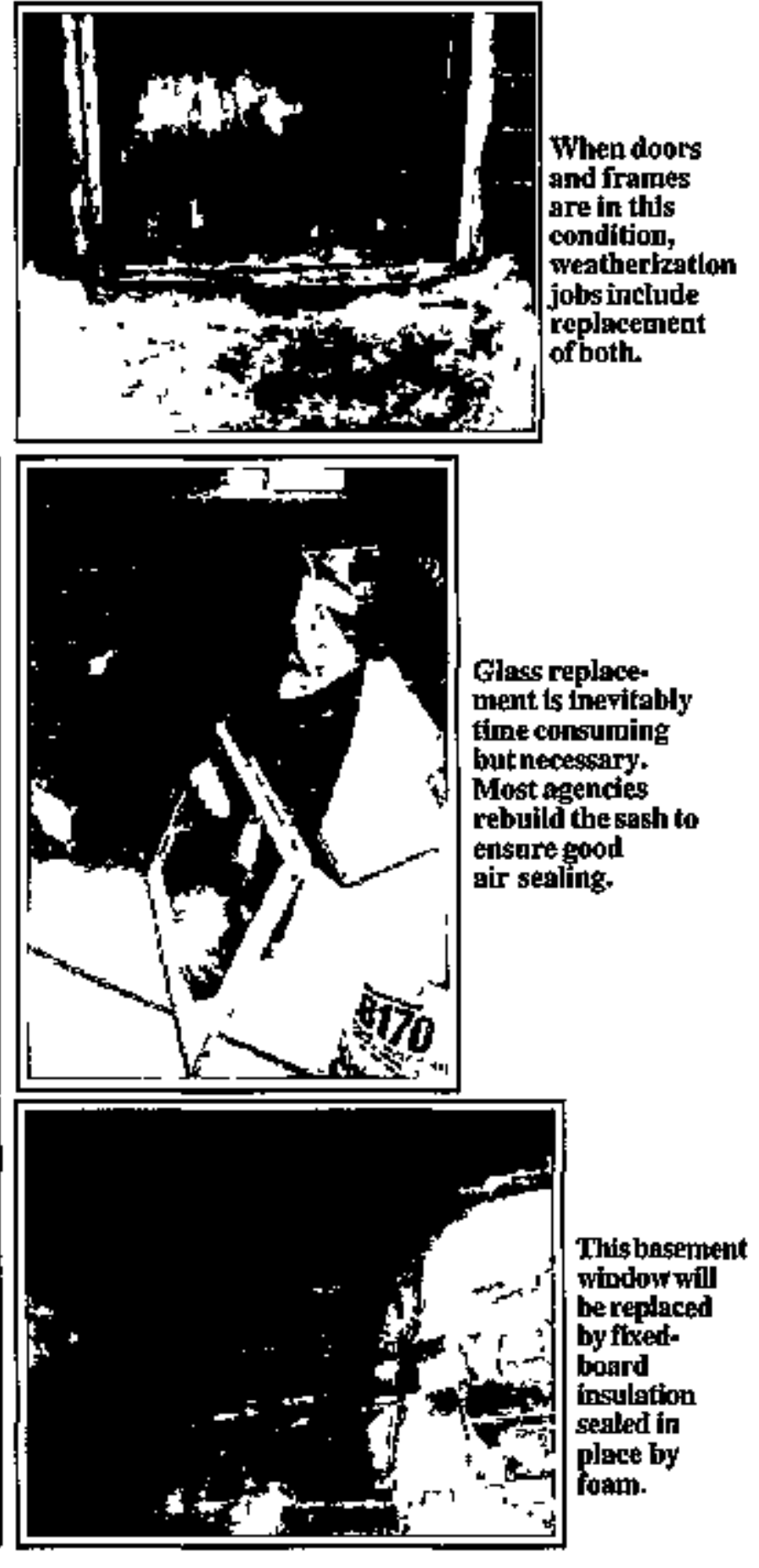
The new policy in Chicago is to weatherize whole buildings, which allows for working on heating systens before treating themal losses in apartments. Frequently, the new policy results in the replacement of large, inefficient boilers and the integration of modem electronic controls. In all cases, whenever major measures such as boiler replacements or largescale window replacennents are undertaken, buitding owners are required to bear 50 percent of the costs. In smaller buildings where tenants can control their own heat, digital thermostats are frequently installed.

Weatherization agencies in Minnesota weatherize about 1,000 large multifamily units each year, most of which are in the MinneapolisSt. Paul area. These units range from row houses to 20 -story bigh-rise buildings, but the most common are two- and three-story frame walk-ups with brick facades. Larger building wotk concentrates on boiler repair, controls, and distribution systems, with little enphusis on window repair work or even air sealing. Smaller buildings are air sealed (with emphasis on attic bypasses) and insulated like single-farnily dwellings. Multifamily work is guided by information from fuel bills and instrumented audits.

Weatherization of large bujldings in ow nation's largest cities is a complex process. There is a growing cadre of technically competent engineers and contractors that is involved in the Weatherization Program's large multifamily retrofits. These individuals practice such important crafts as making single-pipe stearn systens work efficiently. When their practical wisdom is communicated clearly to building supervisors, systems tend to be maintained much better, with the consequence that savings endare. These long-term energy savings can play a key cole in the revitalization of distressed neighborhoods in our nation's larger cities.

\section{B. Sources of Funds}

Suurces of DOE Weatherizalion Program Funds

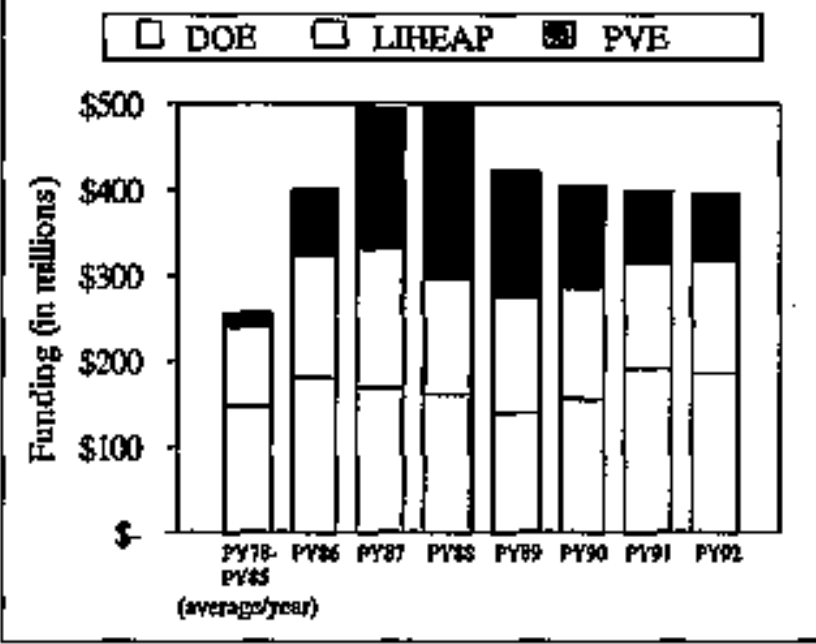

To implement the Weatherization Program, DOE provides money to State Weatherization Agencies, more than 80 percent of which are located within executive departments responsible for humbn services, community development, or economic development. In turm, these agencies allocate funds to local agencies, of which 81 percent are private, nonprofit Community Action Agencies. Most of the remaining entities are lockl or county governmental agencies and Native American tribes. The weatherization work is done by employees of these local agencies or by contractors.

Although other organizations fund and implement Jow-income weatherization programs, DOE has been the dominant source of funding for low-income weatherizalion. Between 1978 and 1996, DOE provided 45 percent of total furding. More investment was made in low-income veatherization in the late 1980's than in earlier years, and considerably less in the 1990's than in the 1980's. More homes have

Three Major Sources of DOE Weatherjzation Program Funds, 1978 to 1992 been weatherized in cold states than in warm states, which partly reflects the formula used to allocate DOE's funds in the 1980's. That formula 


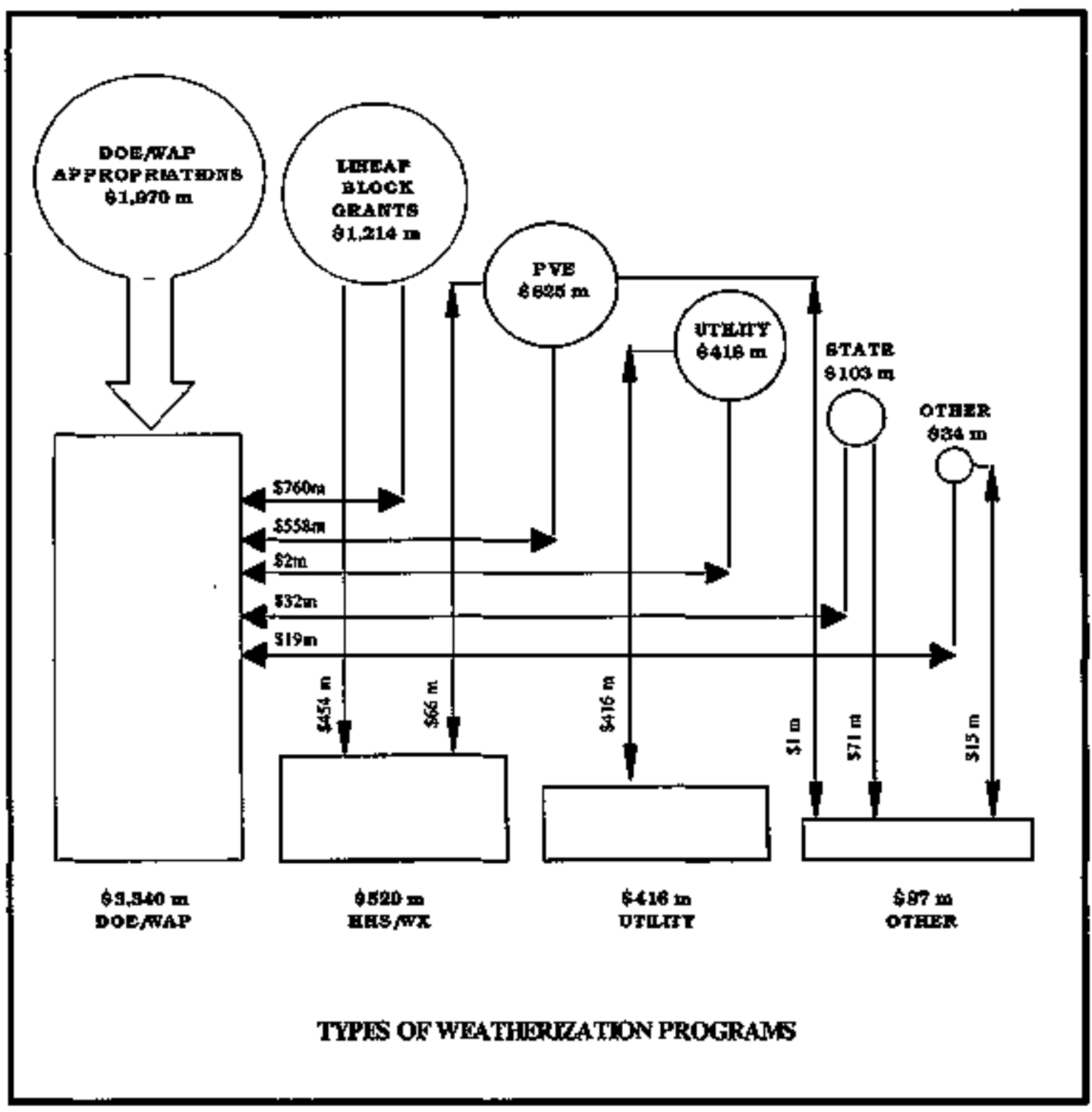

Defintitons of Progant Types:

DOE/WAP = funds spert Inder DOE Weatherization Brogram niles and regulatons.

Walliy = futsds spens in utlltiy programs independent of DOOE's niles and regutations
HHSF $W X=$ funds spent

under HHS LJEEAP

guidelines and not DOE's

miles and regulations.

Odher a funds spent in tate wetherization programs or oberindependent prognams. 
Major Runding Sources for the DOE Weatherization Progran Decreased Sharply in 1996

DOE Funding for DOE Weatherization (in zitlions)

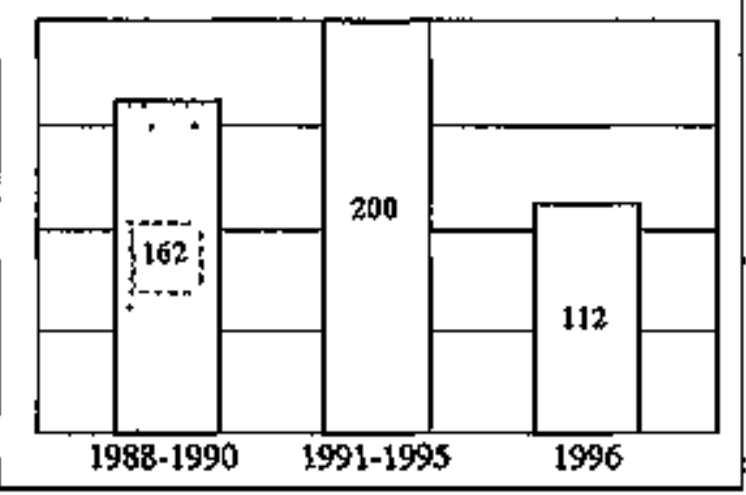

LIHEAP Funding for DOE Weatherization (in millions)

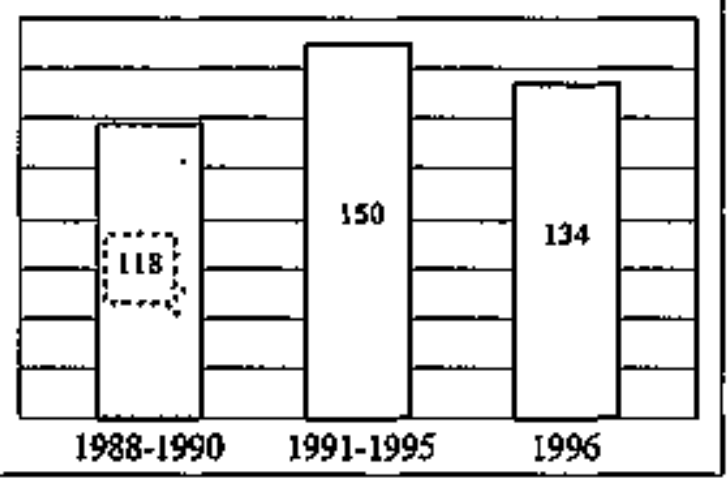

PVE Funding for DOE Weatherization (an millions)

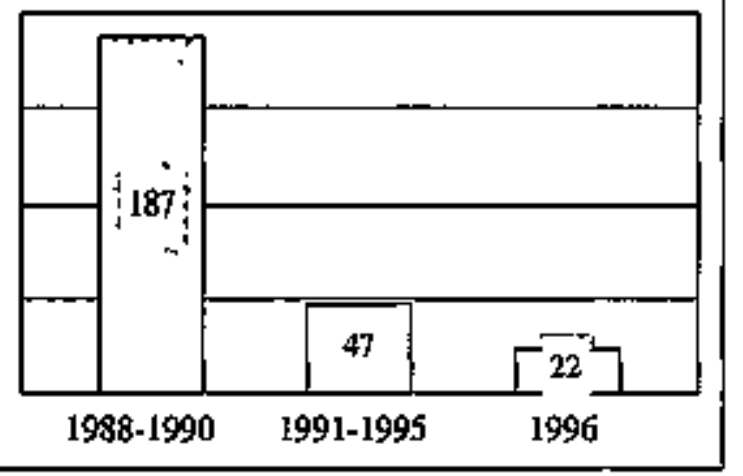

weighted heating degree days much more heavily than cooling degree days. In 1995, the funding formula was changed to increase the proportion of funding going to warm climate states. The intent of the changes was to provide warm climate states with a greater share of the funding while protecting the Program capacity of the states with cooler climates. The revised formula empiasizes all residential energy expenditures (including heating and cooling costs). It provides states with a fixed base amount derived from the FY 1993 allocation. Funds in excess of those needed to meet the base amonnts are allocated according to the revised formula. On a national level, DOE funding for its 1996 program totaled $\$ 111.5$ million, which cormpares to DOE funds of $\$ 214.8$ million in 1995. This nearly $50 \%$ reduction in funding in one year's time was the result of budget cuts passed by the $104^{\text {th }}$ Congress.

In the 1980s a major source of weatherization resources was the Low-Income Home Energy Assistance Program (LLHEAP), administered by HHS. Since 1982, states have had the flexibility to allocate op to 15 percent of LIHEAP funds (now 25 percent after receiving a waiver) to energy conservation measures. Total LIHEAP funding peaked in 1987 and has since declined. In 1996, LIEEAP funds were about 72\% of what they were in 1989. In spite of the reduction in total LIHEAP funding, however, the anount of LIHEAP funding spent on weatherization has actually increased. In 1989 , \$106.1 million in LIFEAP funds were spent on weatherization. In 1996, \$134.0 million in LJHEAP funds were used for weatherization. This increase in LFFAP contributions to weatherization, during a time when its overall budget declined, suggests that weatherization is seen as an especially effective way of producing a long-term reduction in the energy burdens of low-income households.

A third major source of weatherization money in the 1980s was the Petroleum Violation Escrow (PVE) Fund. These funds came from legal penalties assessed against oil companies convicted of violating price controls. The exhaustion of PVE funds devoted to low-income weatherization on a one-time basis was the most dramatic cause of the decline in total weatherization funding from 1987 to 1992 . State program managers indicated that total funding for low-income weatherization dipped 30 to 40 percent between 1990 and 1994, primarily because of the exharstion of PVE funds.

Utilities provided 9.6 percent of funding available for tow-income weatherization between 1978 and 1989 . Utility programs and funding were responsible for 22 percent of all units weathetized during that 12-year period. Among the 49 utilities that spent $\$ 418$ million on energy measures between 1978 and 1989 the average investment per unit was only about one-third as much as in the DOE Weatherization Program. A sniall amount of funding for low-income weatherization came 


\section{THE GEOGRAPHY OF UTAITY PROGRAMS}

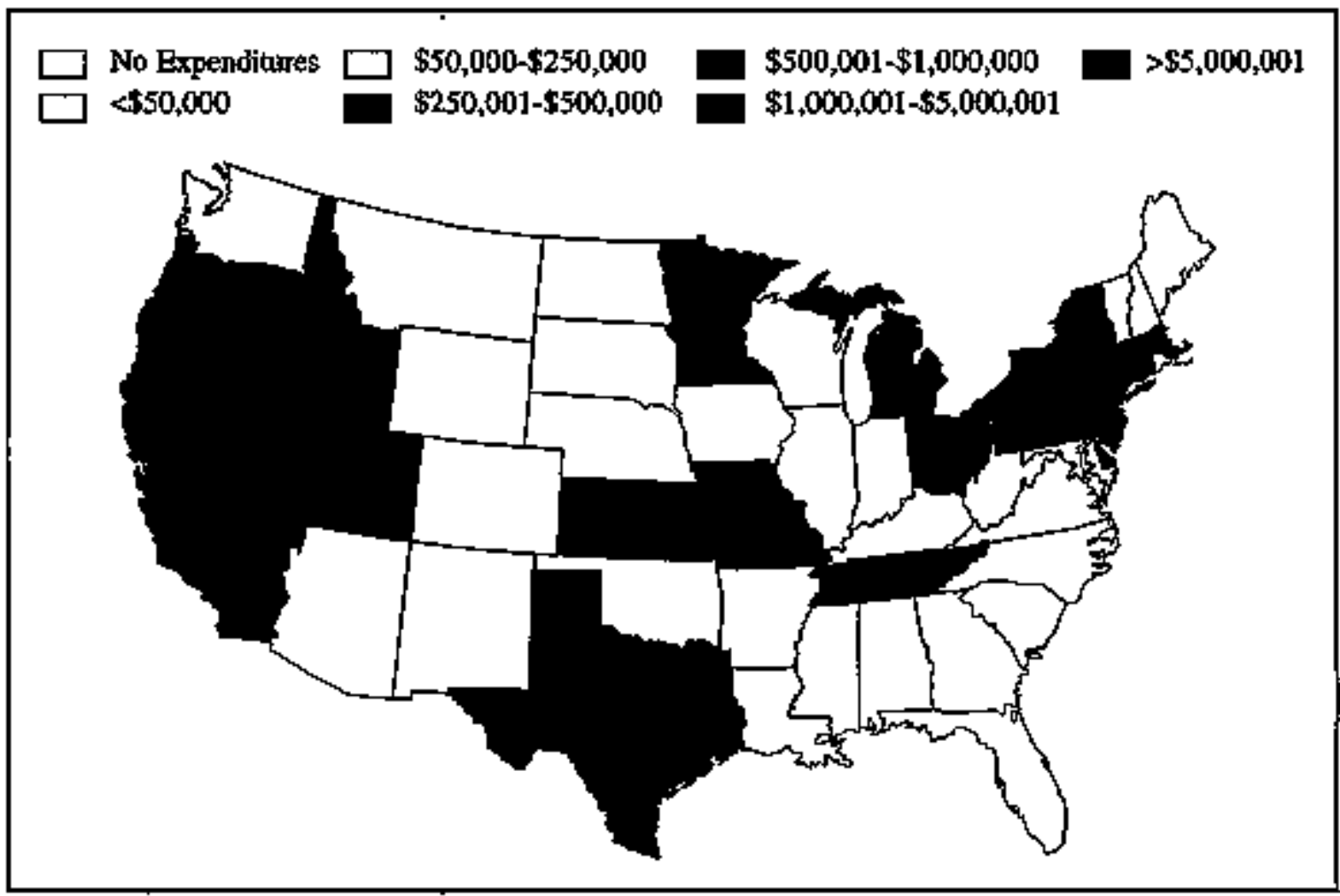

Geographic Distribution of Utility Expenditures on Low-Income DSM Prograns in 1992

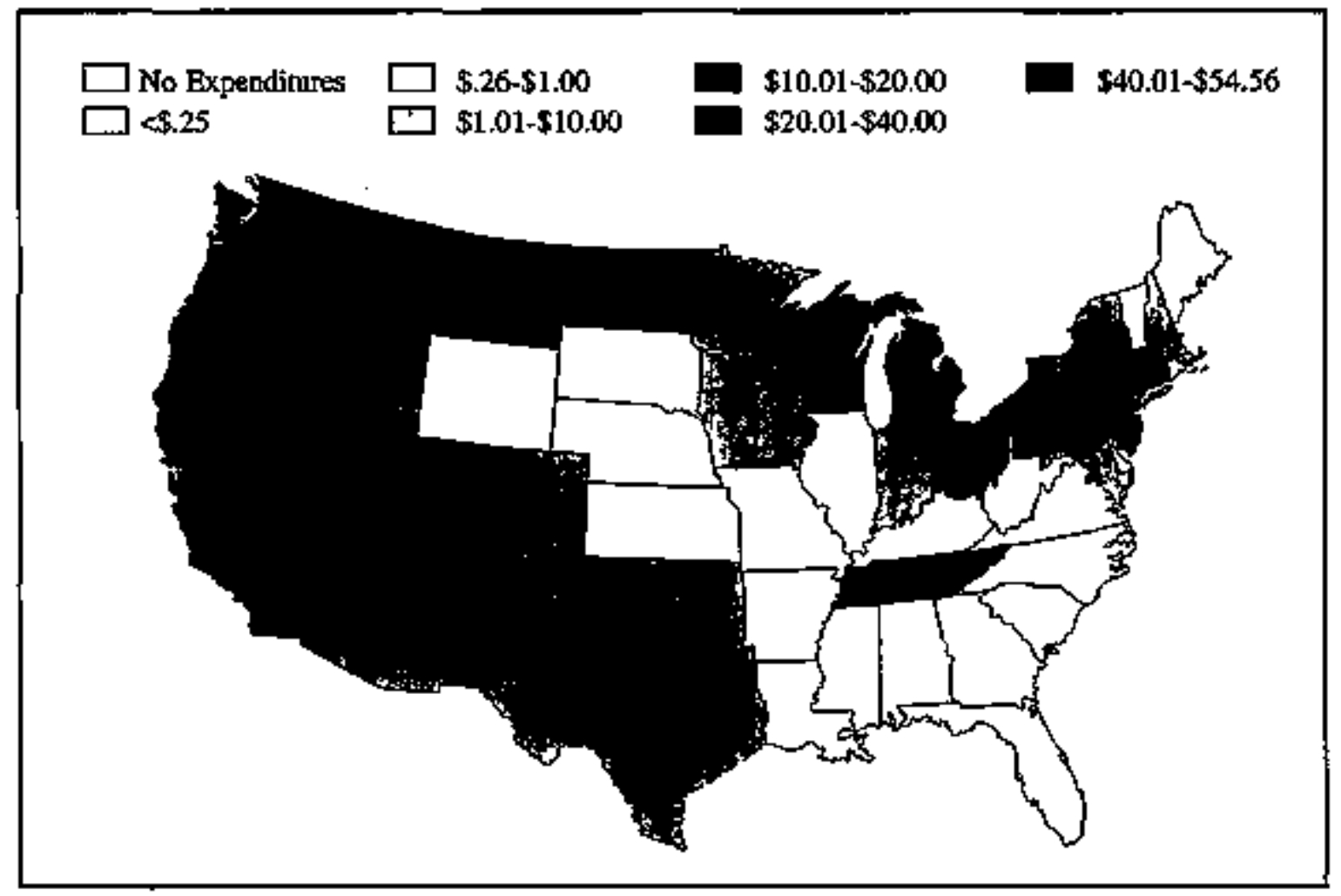

Gengraphic Distrlbution of Utility Expenditures per Low-Income Honsehold in 1992 
from miscellaneous other sources, inclnding owners of rental housing weatherized onder the Prograns and state weatherization programs, which in some cases emphasized comprehensive home repair or heating system retrofits.

The impending restructuring of the electric utility industry poses uncertain prospects for continued utility funding of low-income programs. Past programs to assist low-income households with energy efficiency have been funded through regulated utility rates, but obtaining lowincome funding may become more difficult in a more competitive and less regulated industry structure. The Weatherization network has been actively presenting low-income interests and concens to policymakers in state regulatory commissions and legislatures. As a result of these efforts, restructuring programs in states such as California and Massachusetts, which have been the first to initiate restucturing, have continued funding for low-incone energy efficiency. The Weatherization network also continues to be successful in securing fanding from utilities in other states where the pace of change is slower and traditional regulation remains firmly in place.

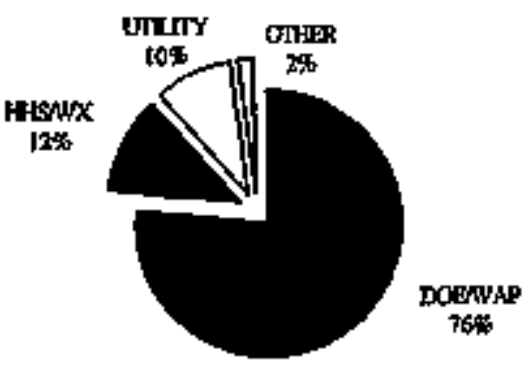

C. Uses of Funds: DOE Sets the Pace

Regardless of its source, most funding for low-income weatherization has been spent according to DOE's Weatherization Assistance Program rules. By law, all funds appropriated to the Progran by $\mathrm{DOE}$ are governed by $\mathrm{DOE}$ rules and regulations. In contrast, funds appropriated by LifHEAP can be spent by that program's much broader guidelines, which have allowed, for example, greater expenditures on furnace and boiler retrofits and replacements. Similarly, utility low-income DSM programs and state funding for weatherization can be spent as the funding agency deems appropriate.

In practice, 76 percent of all low-income weatherization money spent in the 12-year period between 1978 and 1989 was gujded by DOE rules and procedures. Before 1989, about 12 percent was spent in programs under LIHEAP regulations. Today the percentage of funds spent under LIHEAP regulations has risen to 35 percent. DOE's central role in directing weatherjzation activities nationwide is underscored by the fact that the vast majority of non-DOE funds bave been channeled through the Program. This distribution process also indicates the importance of the new Program rules in guiding future weatherization activities.

\section{Utillty Paramerships}

Utility programs made significant contributions to the effort to weatherize low-income dwellings. According to Power et al. (1992), 102 utility low-income energy-efficiency programs operated in 1989, with investments totaling $\$ 97$ million (or $\$ 109$ million, expressed in 1992 dollars). By 1992, these numbers had increased to 132 programs with an annual expenditure of $\$ 141$ million (Brown et al., 1994). 


\section{PROFILES OF SIX COORDINATED PROGRAMS}

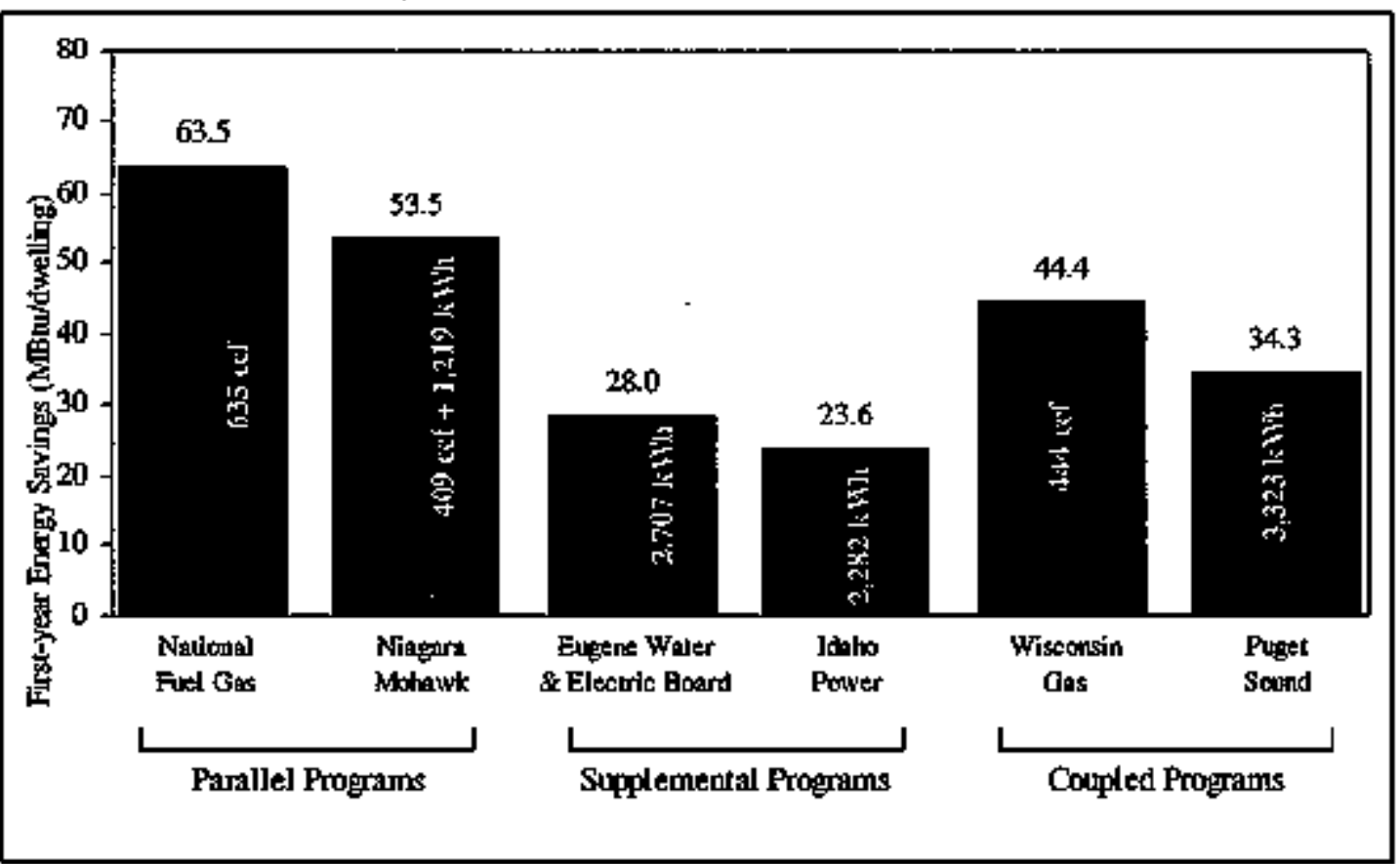

Furst-Year Energy SaYings of Stx Coortiaated Programs

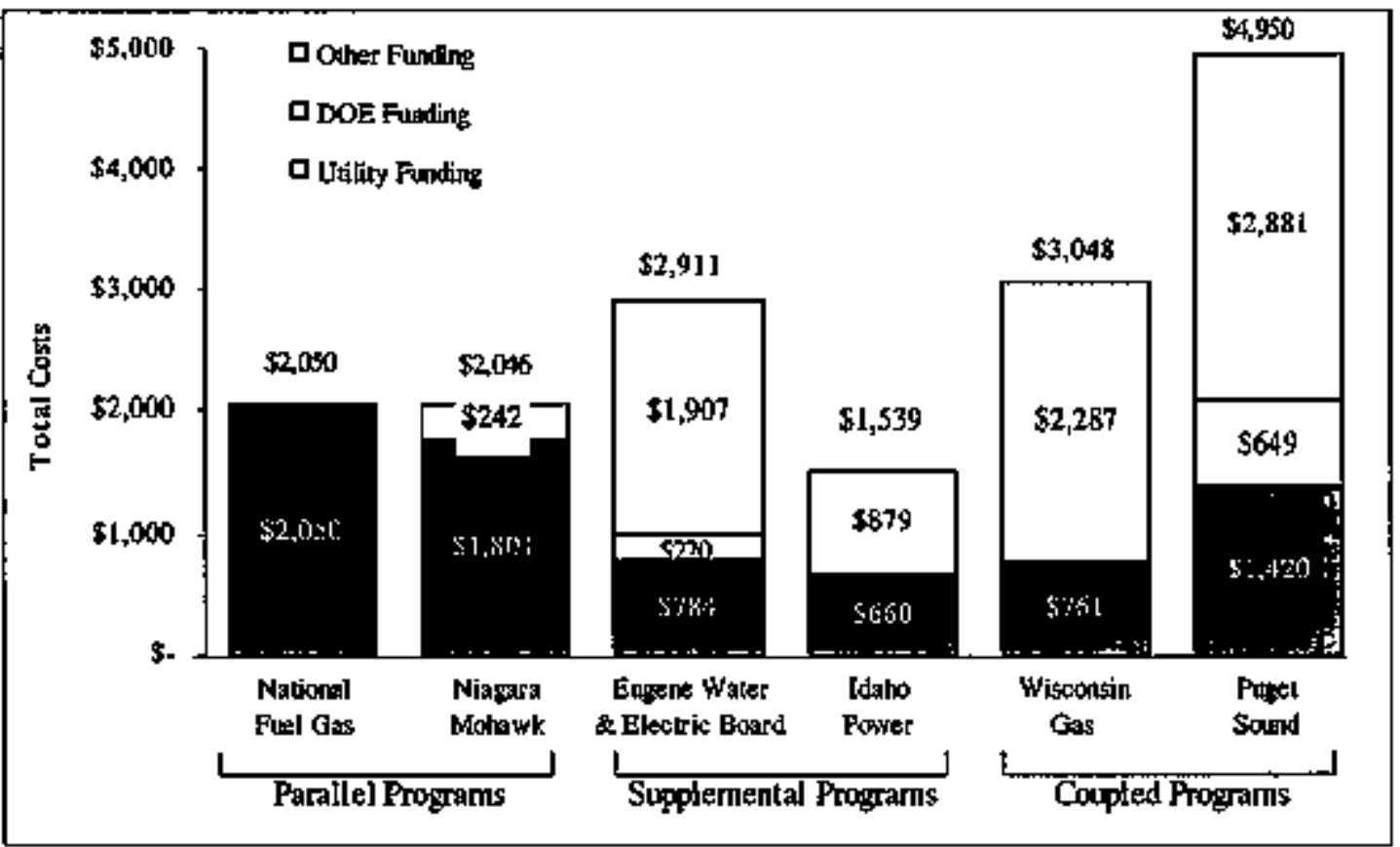

Costs of Six Cooatinated Programs by Source of Funding 
Utility programs tend to be concentrated in a few states where weatherization services for low-income customers have been mandated by regulatory bodies. On average, utility-sponsored low-income programs invest about one-third as much per dwelling as the DOE Program. Unlike the DOE Weatherization Program, many of the electric atility programs for Iow-income customers focus primarily on lighting and appliance measures. Water-heating measures (particularly low-flow showerheads) are common to both gas and electric utility low-income programs. "Major" measures such as attic, wall, and floor insulation and stom windows are less common in these utility programs than in DOE's Weatherization Program.

By pooling utility and government resources in "coordinated" programs, utilities are able to offer more comprehensive weatherization to their low-income customers. Thre types of utility low-income partnerships exist, which involve varying degrees of coordination between government and utility cosponsors (Brown and Hill, 1994).

-Parallel Programs. In these cases, the local weatherization agency operates two parallel programs-one funded by government grants and the other funded by utility contracts. The utility simply employs the agency as a subcontractor to deliver energy-efficiency services to lowincome households. The utility-funded program is coordinated in the sense that some of the same staff and equipment are used by both programs.

-Supplemental Programs. These programs use utility funds to supplement the agency's government-funded weatherization program, with no changes to the operation of that program. The result is more weatherized homes, more comprehensive weatherization, or both.

-Coupled Prograrns. These programs employ a combination of utitity and govemument funds to deliver weatherization services as part of an integrated program that is distinct from the agency's preexisting government-funded program. This type of program has the potential to outperform para!lel and supplemental programs by taking advantage of the unique capabilities of each cosponsor.

Each of these types of coordinated programs provides utilities with access to trained weatherization professionals and associated equipment, which is often quite sophisticated and conducive to high-quality weatherization. In many regions of the country, there is a scarcity of such capability. In addition, community action agencies are often uniquely qualified to tackle the problems associated with substandaro shelter.

Brown and Hill (1994) conducted case studies of six coordinated low-income weatherization programs. All six programs achieved impressive levels of energy savings. For the three coordinated gas programs, annual savings ranged from 409 to 635 ccf (hundred cubic feet) per dwelling, and for the three electric utility prograns, annual savings ranged from 2,282 to 3,323 kWh (kilowatt-hours) per dwelling. Costs for the six coordinated programs ranged widely from $\$ 1,539$ to $\$ 4,950$ per dwelling. This range of costs is high relative to the amount typically spent in the DOE Weatherization Program, which averaged $\$ 1,550$ per dwelling in 1989. In 


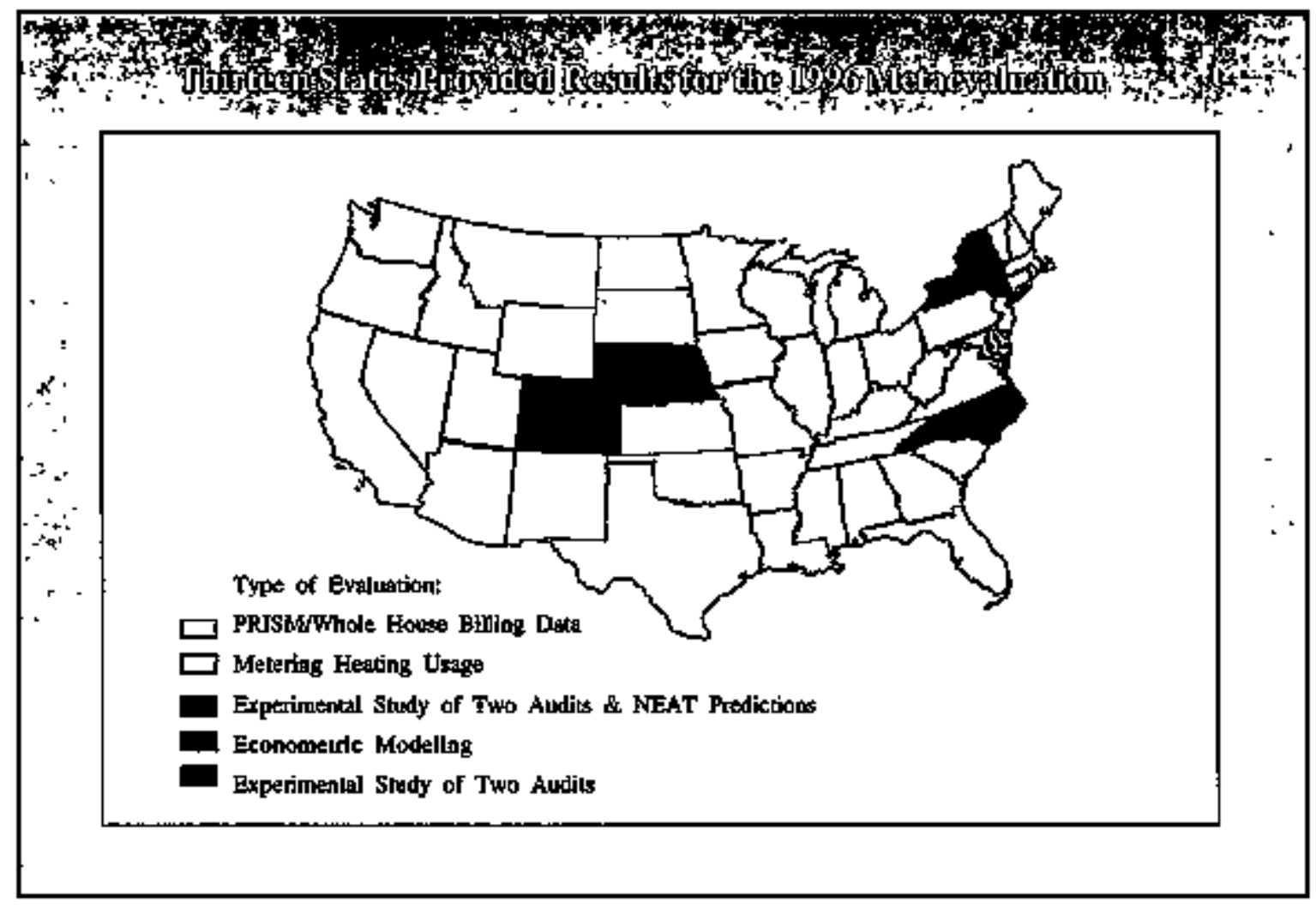

Estimated National Program Energy Savings in 1989 and 1996 in Homes that Heat Primarily with Natural Gas

\begin{tabular}{|c|c|c|c|}
\hline & $\begin{array}{l}\text { Mlftu of } \\
\text { Natural Gas } \\
\text { Sared per } \\
\text { Dwelling }\end{array}$ & $\begin{array}{c}\text { Percentage } \\
\text { Rednctlonbn } \\
\text { Natural Gas } \\
\text { Consumption } \\
\text { for Space } \\
\text { Heating }\end{array}$ & $\begin{array}{c}\text { Percentage } \\
\text { Rednctlonin } \\
\text { Natural Gas } \\
\text { Consumption } \\
\text { for All End } \\
\text { Ujes }\end{array}$ \\
\hline $\begin{array}{l}\text { National } \\
\text { Evahuation Results } \\
\text { for } 1989\end{array}$ & 17.3 & $18.3 \%$ & $13.0 \%$ \\
\hline $\begin{array}{l}\text { Metgevalnation } \\
\text { Resnits for } 1996 \\
\text { Based on } \\
\text { Regression Model }\end{array}$ & 31.2 & 33.5\% & $23.4 \%$ \\
\hline
\end{tabular}




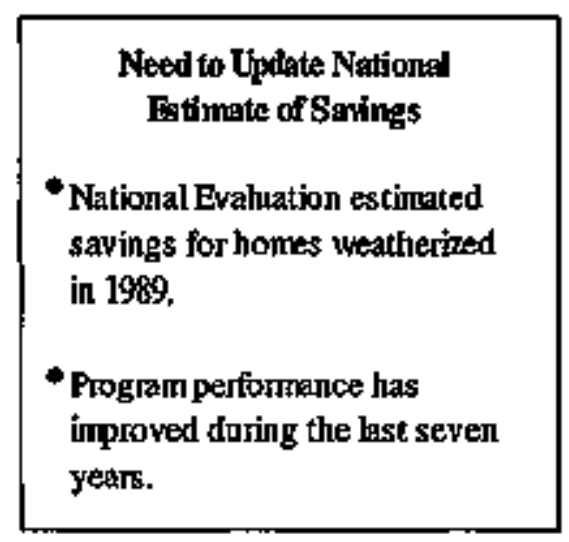

Objectives of Metaevaluation

- Locate state-level evaluations

- Review evaluations

- Organize findings

- Develop method of applying state-level findings to nation

- Estimate regression models

- Apply model results to bational inpats to develop pational estinate

Ten States Wto One Ealuation

- Colorado (1993-1995)

- Indiana (1991-1992)

- Kansas (1992)

- Nobraska (1994)

- Now Yodk (1990)

- North Carolina (1990)

- North Daksta (1990-1992)

- Tezas (1991-1992)

- Wisconsin (1992)

- Wyoming (1990)

Three States With More Than One' Exalantion

- lowa (1992-93) and (1995)

- Ohio (1990-91), (1993-94), and (1994-95)

- Vemont (1992-93) and (1993-94) addition, it is much higher than the typical investment levels of stand-alone utility-operated low-income weatherization prograns.

The utilities and conmunity action agencies managing each of the six coordinated programs indicated that the benefits of coordination far outweighed the costs.

\section{METAEVALUATION METHODS AND RESULTS FOR 1996}

A number of state Program offices conduct periodic evaluations of the enexgy savings produced by their efforts. With the help of these offices, a metaevaluation of 17 state-level evaluations conducted since 1990 was recently completed for DOE by Oak Ridge National Laboratory.

The state-level evaluation results were used to produce the estinate of national savings for 1996 discussed below (Section A). This estimate was developed by summarizing and integrating the findings of the state-level evaluations (Berry, 1997). The results are only for homes heating with natural gas, the only fuel for which all of the state-level evaluations provided results. Three of the thirteen states with evaluations conducted sirice 1990 had evaluated their Program more than once in the last seven years.

The approach chosen to estimate the 1996 rational savings was to use regression modeling to develop the best linear equation for predicting savings. The data from the 17 recent state-level evaluations (1990-1995) were used to develop this predictive tool. Then the parameters of the best predictive model were applied to the appropriate average national input values for each predictor in the eguation. For example, the average heating degree days for the available evaltations was 5,942 . Nationally, the population weighted 30-year average of heating degree days is 4,499 . Therefore, the national average of 4,499 heating degree days was used as the input to the regression model used to predict national savings. For the most part, national input values were taken from the National Evaluation, which was based upon a representative national sample. Details of model development and of the rationale for selecting specific national input values are given in Berry (1997).

\section{A. Three Methods Show Trend Toward Egher Savings}

Regression Analysis. The key finding of the Metaevaluation's regression analysis is that, in the last seven years, improved practices have produced $80 \%$ higher average energy savings per dwelling. The most recent comprehensive evaluation of the Program was based on an analysis of changes in pre- and post-weatherization energy consumption for a representative national sample of homes weatherized in 1989. This National Evaluation found that dwellings that heated primarily with natural gas, which made up over $50 \%$ of the national sample, had average savings of $17.3 \mathrm{Mbtu}$ per dwelling, which was $18.3 \%$ of space heating consumption, or $13.0 \%$ of the total consumption of natural gas for all end 


\section{METAEVALUATION FINDINGS}

Predietive Value of Fit for the Turee-Variable

(Pre-Weatberiation Consugpton, Year, Audtt Type)

RegressionModel

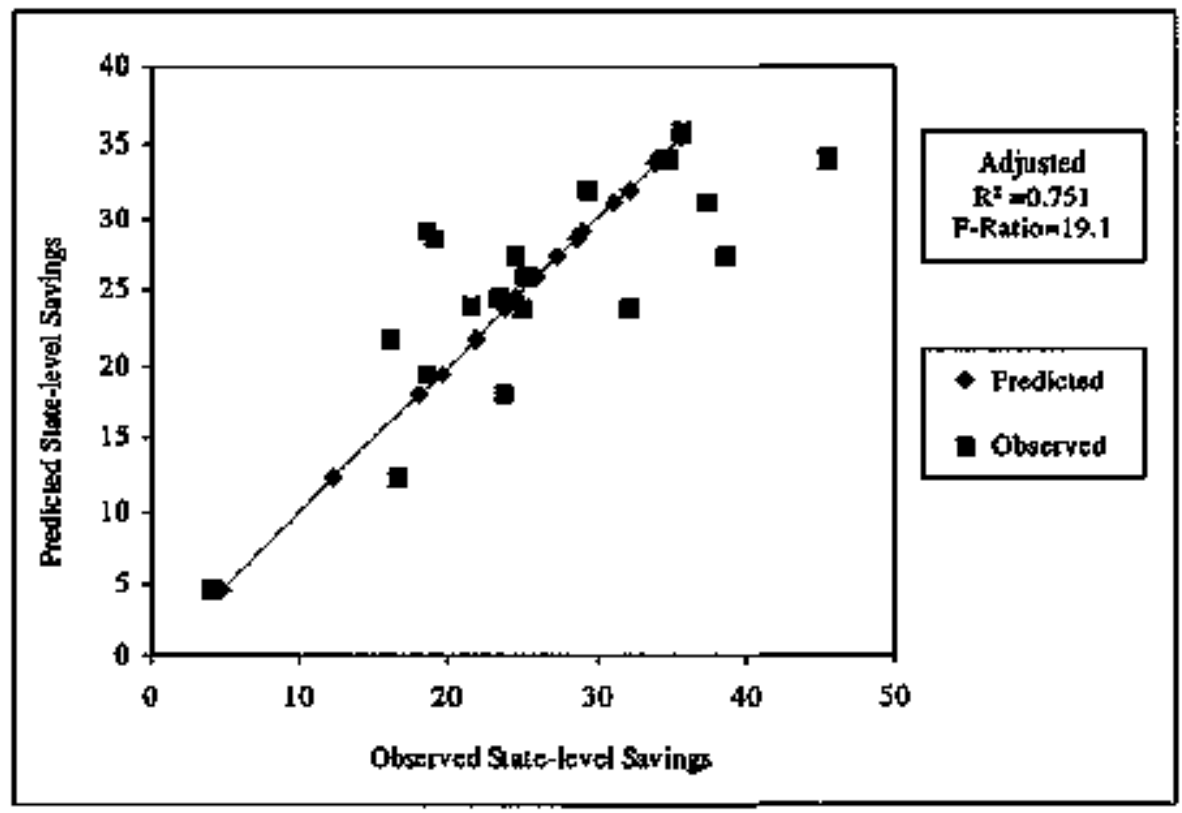

Literature Revew Finctings on Central Tendencies Characterizing the Percentage of Fhergy Saings in 1981-1989 and in 1990-1996

\begin{tabular}{|c|c|c|c|c|c|}
\hline & $\mathbf{n}$ & Median & Mean & $\begin{array}{c}\text { Interquartile } \\
\text { Rame }\end{array}$ & Range \\
\hline $1980 \% 89$ & 25 & $12 \%$ & $13 \%$ & $12-16 \%$ & $6-23 \%$ \\
\hline $1990-96$ & 17 & $20 \%$ & $22 \%$ & $18-24 \%$ & $13-34 \%$ \\
\hline
\end{tabular}

Upward Trends in Fnergy Savings in Ohio, Vermont, and Iowa

\begin{tabular}{|c|c|c|c|c|c|c|c|c|}
\hline \multicolumn{3}{|c|}{ Ohio } & \multicolumn{3}{|c|}{ Vermont } & \multicolumn{3}{|c|}{ Iowg } \\
\hline & Mhlon & Percent & & Mbsu & Percent & & Mhtu & Peremat \\
\hline 1990-91 & 20.5 & $12.6 \%$ & 1992-93 & 18 & $17.8 \%$ & 1992.93 & 25.2 & $18.6 \%$ \\
\hline $1993-94$ & 29.3 & $20.4 \%$ & 1993-94 & 24.5 & $20.1 \%$ & 1993-94 & n/a & na \\
\hline 1994-95 & 310 & $22.5 \%$ & $\mathbf{E} / \mathrm{A}$ & $\mathrm{r} / \mathrm{a}$ & w/a & 1995 & 27.3 & $21.7 \%$ \\
\hline
\end{tabular}


nses (Brown, Beryy, Balzer, and Faby, 1993). The Metaevaluation of statelevel evaluations of the Program, which developed a regression-based national estimate of savings, indicated that savings in 1996, in homes using natural gas as the primary heating fuel, were $31.2 \mathrm{Mbtu}$, which was $33.5 \%$ of natural gas space heating consumption, or $23.4 \%$ of the total consumption of natural gas for all end uses (Berry, 1997).

Literature Review Findings. In addition to the regression modeling results summarized above, two additional types of evidence (from a literature review and from comparisons within the same state over time) demonstrate the trend toward increased Program energy savings.

\section{At Same Levels of Pre-Weathertzatton Consumption, Most Evaluations Conteled Since 1990 Show Ejgher Savings Than in 1989}

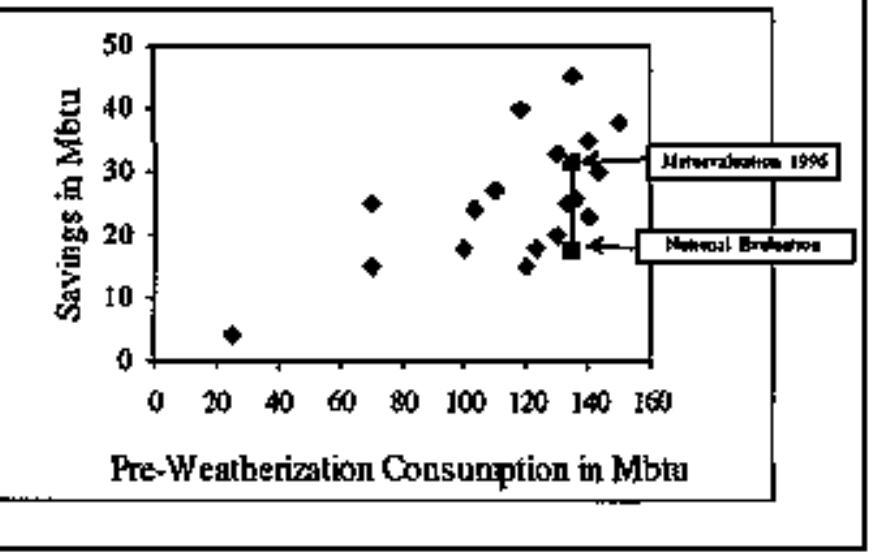

Six years before conducting the 1996 Metaevaluation, ORNL completed a similar task in preparation for the National Evaluation. That task was a literatore review (which was completed in 1990) and is presented in Section 1.4 of Brown et al., (1993). Comparisons of findings from the 1990 and 1996 literature reviews show a trend toward increased savings. The 1990 literature review concluded that the state-level evaluations avalable at that time (covering the years of 1981-1989) showed typical energy savings (expressed as the percentage reduction in the total consumption of the primary heating fuel) of between $12 \%$ and $16 \%$, with a range of $6 \%$ to $23 \%$ savings in various loctions. The 1990 literature review also concluded that a number of demonstration projects indicated that the Program could potentially achieve much greater savings ( $25 \%$ to $40 \%$ ). The similarity in findings from that literature review (i.e, expected average savings of $12 \%$ to $16 \%$ ) and the results of the National Evaluation (13.0\% of the total consumption of natural gas for al] end uses or $18.3 \%$ as a percentage of consurnption for space heating) created confidence that a review of the state-level evaluations conducted since 1990 would also yield a reasonably accurate current estimate of national savings. The 1996 review of state-level evaluations covering weatherizations performed in 1990 through 1996 showed typical savings of $18 \%$ to $24 \%$ (expressed as the pencentage reduction in the total consumption of the primary heating fuel), with a range of savings from $13 \%$ to $34 \%$. 


\section{Sone Reasons for Improved Program Performance in 1996}

Shift From Ptionity Lists to Adranced Audits

No advanced andits in 1980's

37 States used advanced audits in 1996

More Llse of Blower-Door Directed Air Sealing

Increased Targeting of Dwellings With High Poteratial for Savings

Revised DOE Regulatjons That Pronote More Cost-Effective

Tailoting of Measures to the Specific Needs of Individual

Dwellings and Regions

Removed batriers to beatiog system efriciency measures

Allowed cooling measures

Promoled use of advanced audfts

\section{Nonenergy Benefits are Numerous and Mnportant}

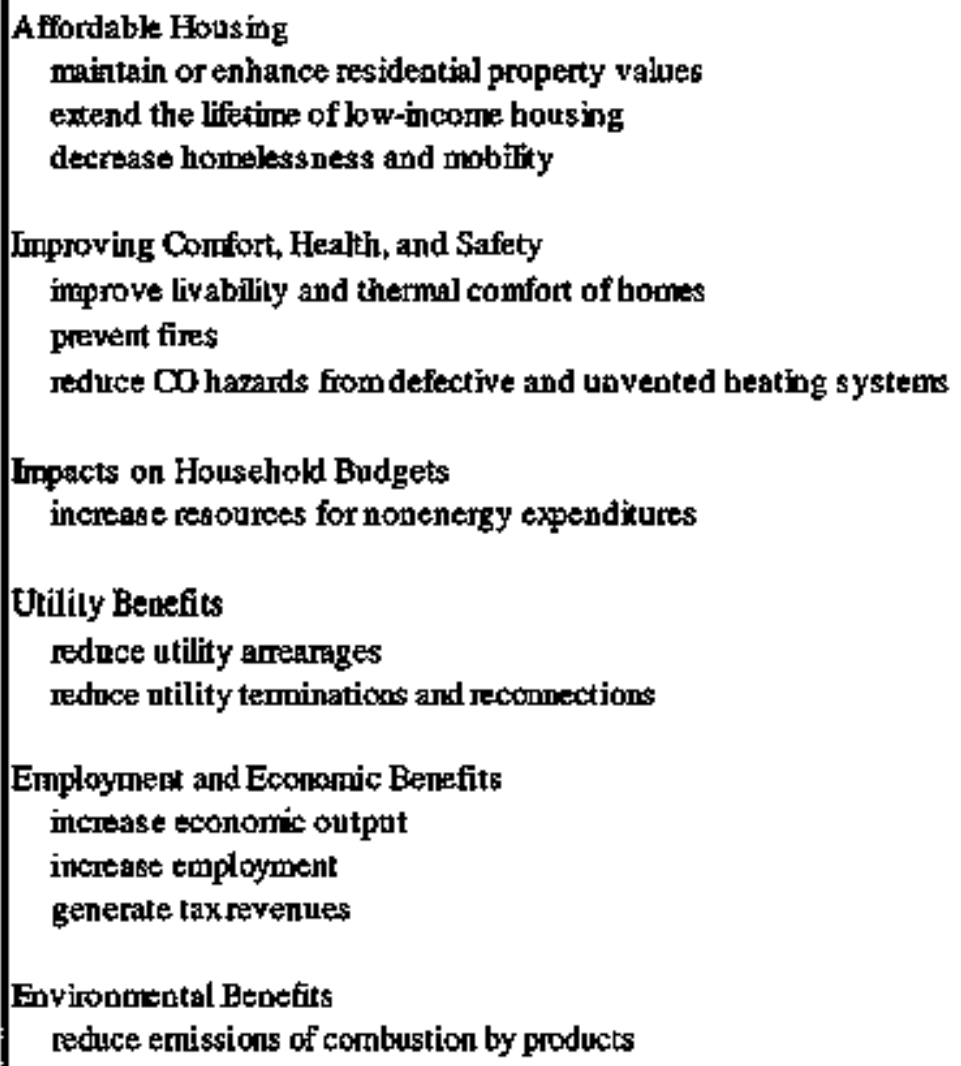


Trends within States. Three states for which savings could be compared over time - Iowa, Ohio, and Vermont - all showed significant increases in savings. The trend toward increased savings over time in these states is anmistakable.

\section{B. Reasons for Increases in Program Savings}

Several reasons exist for the trend toward higher savings. Three important technical improvernents are discussed below.

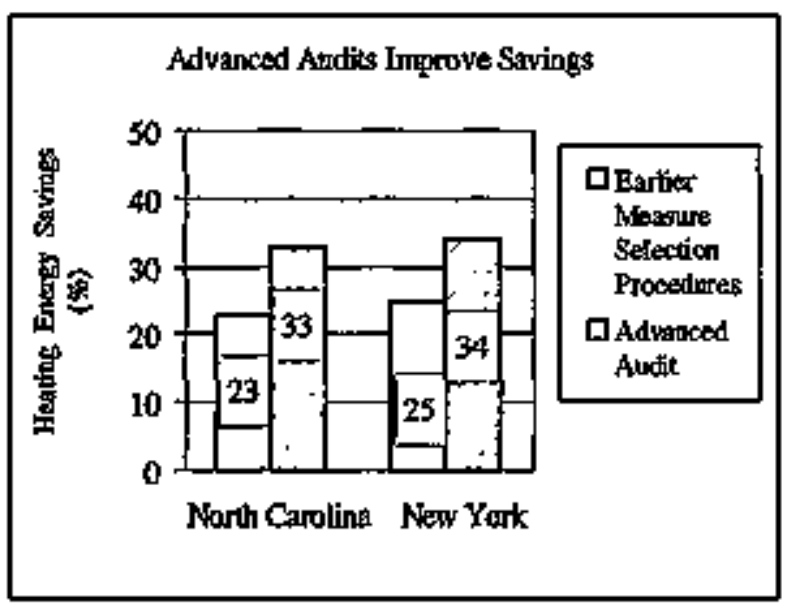

Advanced andits had not yet been introduced in 1989. Today 37 states use them. Two demonstration studies, one in New York and one in North Carolina, have shown the saperior energy savings achieved with the use of advanced andit procedures (New York State Energy Research and Development Authority and New York State Department of State, 1993; Sharp, 1994). In North Carolina the introduction of an advanced audit increased heating energy savings from $23 \%$ to $33 \%$. In New York, saving increased from $25 \%$ to $34 \%$.

Blower-door difrected air sealing is another important technology that has contributed to the trend toward increased savings. In 1989 only a few states used this technology; now most do. With the use of blower doors to goide air sealing, investments in air infiltration reduction will produce higher savings.

Targeting high-energy consnmers is a Program management technique that produces higher savings. More agencies use this practice today. Many studies have shown that bigh pre-weatherization consumption is the best predictor of high energy savings (Brown et al., 1993; Columbia Gas of Ohio, 1995; Pennsylvania Public Utility Commission, 1994, Berry, 1997).

Additional reasons to expect a trend toward higher energy savings relate to the implementation of Program regtlations designed to capture opportunities for improvement. Among the revised DOE regulations issued in 1994 were changes that promote the use of advanced audits and permit the use of cooling efflclency measures such as air conditioner replacements, ventiłation equipment, and screening and shading devices.

\section{Nonenergy Benefits of Weatherization}

Most of the state-level evaluations did not address the issue of the nonenergy benefits of weatherization at all. Only one, the Iowa evaluation, gives mutch attention to nonenergy benefits. The Iowa evaluation botes that the potential benefits of weatherization include:

- improved client safety and health;

- reduced utility collection costs and write-offs;

- improved property value, longevity, and maintenance of affordable housing. 
Smmuary of 1994 Regulatory Changes Governing DOE's Weatherization Program

\begin{tabular}{|c|c|c|}
\hline & OLDRULES & NEW RULES * \\
\hline $\begin{array}{l}\text { Weatherization } \\
\text { materials and } \\
\text { measures }\end{array}$ & $\begin{array}{l}\text { Services provided inclnde: } \\
\text {-air sealing } \\
\text {-caulking and weather stripping } \\
\text {-furnace and boiler tune-up, } \\
\text { repait, and replacement } \\
\text {-cooling system tune-up and } \\
\text { repair } \\
\text {-replacing windows and doors } \\
\text { and adding storm windows } \\
\text { and doors } \\
\text {-insulating attics, walls, and } \\
\text { foundations } \\
\text {-clienteducation }\end{array}$ & $\begin{array}{l}\text { Addedthe following: } \\
\text {-replacement air conditioners } \\
\text {-ceiling, attic, and whole-honse } \\
\text { fans } \\
\text {-evaporative coolers } \\
\text {-screening } \\
\text {-window films }\end{array}$ \\
\hline $\begin{array}{l}\text { Materials } \\
\text { requirement }\end{array}$ & $\begin{array}{l}40 \% \text { of funds must be spent } \\
\text { on materials }\end{array}$ & $\begin{array}{l}\text { Waiver of } 40 \% \text { requirement } \\
\text { may be granted if an } \\
\text { advanced audit procedure is } \\
\text { used }\end{array}$ \\
\hline $\begin{array}{l}\text { Rentalunit } \\
\text { requirements } \\
\text { andprotections }\end{array}$ & $\begin{array}{l}\text { Owner permission } \\
66 \% \text { of eligibility required for } \\
\text { largemultifamily units and } \\
50 \% \text { eligibility required for } \\
\text { duplexes and four-init } \\
\text { buildings } \\
\text { Weatherization benefits to } \\
\text { accrue primarily to low- } \\
\text { income tenants }\end{array}$ & $\begin{array}{l}\text { Expanded renters protection } \\
\text {-benefits and no rent increase } \\
\text { even for renters paying for } \\
\text { entergy throught rent } \\
\text {-States may require financial } \\
\text { participationfromlandlords }\end{array}$ \\
\hline $\begin{array}{l}\text { Eliggibility and } \\
\text { targeting }\end{array}$ & $\begin{array}{l}\text { Up to } 125 \% \text { of poverty, or the } \\
\text { state may elect to use LIHEAP } \\
\text { eligibility criteria } \\
\text { Special consideration given to } \\
\text { the elderly and persons with } \\
\text { disabilities }\end{array}$ & $\begin{array}{l}\text { Special consideration also given } \\
\text { to fanmilies with young } \\
\text { children }\end{array}$ \\
\hline Reweatherization & $\begin{array}{l}\text { Allowed reweatherization of } \\
\text { unitpartially weatherized } \\
\text { from September 30, } 1975 \text { to } \\
\text { September } 30,1979\end{array}$ & $\begin{array}{l}\text { Cut-off date for reweather- } \\
\text { ization extended to } \\
\text { September 30,1985 }\end{array}$ \\
\hline
\end{tabular}

The final version of the new DOE rulemaking was published in the Federal Register of March 4, 1993. 
- reduced environmental impacts from energy production and transport; and

- additional economic activity and jobs for Iowa.

Only the economic activity and job cration benefits were quantiffied in the Iowa study. Using an input-output analysis, the study concluded that each million dollars of Program spending produces about $\$ 240,000$ worth of additional economic activity. This additional economic activity suppotts 5.6 additional jobs (The Statewide Low-Income Collaborative Evaluation (SLICE) of Lowa, 1994). The Iowa study did not assign a specific dollar value to any additional nonenergy benefits. However, it concluded that even conservative estimates of these nonenergy benefits would significantly increase the cost effectiveness of the Program.

In the National Evaluation, an effort was made to quantify the dollar value of some nonenergy benefits. The highest dollar values were assigned to employment and environmental benefits (Brown, Berry, Blazer, and Faby, 1993). The methods used to estimate the dollar value of the range of nowenergy benefits varied. These methods are explained in Chapter 6 of Brown et al. (1993). The final estimate of the net present value of all of nonenergy benefits that were monetized was set at $\$ 976$ per dwelling in 1989 dollars. This is the estimate that is used in the next section to estimate Proggern cost effectiveness from the societal perspective, which is the only perspective that includes nonenergy benefits.

\section{Cost-Effectiveness Resnlts}

Because of the higher average national savings estimated for the Program in 1996, cost-effectiveness estimates also inereased: The National Evaluation used three perspectives' for estimating cost effectiveness:

- the program perspective, which compares energy benefits to total costs;

- the installation perspective, which compares energy benefits to installation costs; and

- the societal perspective, which compares energy and nonenergy benefits to total costs.

\footnotetext{
' In the National Evahuation, three perspectives were used to develop benefitcost ratios; the program perspective, the installation perspective, and the societal perspective. The program perspective compares the discounted value of energy savings to total program costs (including labor, materials, overbead, administracive, and all other categories of both fixed and variable costs). The installation perspective compares the discounted value of energy savings to installation-related program costs (i.e., fnstaltation labor and materials costs). The societal perspective compares the discotnted value of both energy and nonenergy benefits (such as empłoyment and environmental benefits) to total program costs (ilicluding labor, materials, overbead, administrative, and all other categories of both fixed and varjable costs). All three perspectives used an assumed measure lifetime of 20 yers and a disconot rate of $4.7 \%$. To nake the 1996 benefitcost ratios comparable to the National Evaluation ratios the same definitions and assumptions were used.
} 


\section{AIR INFLTRATION/EXFILTRATION}

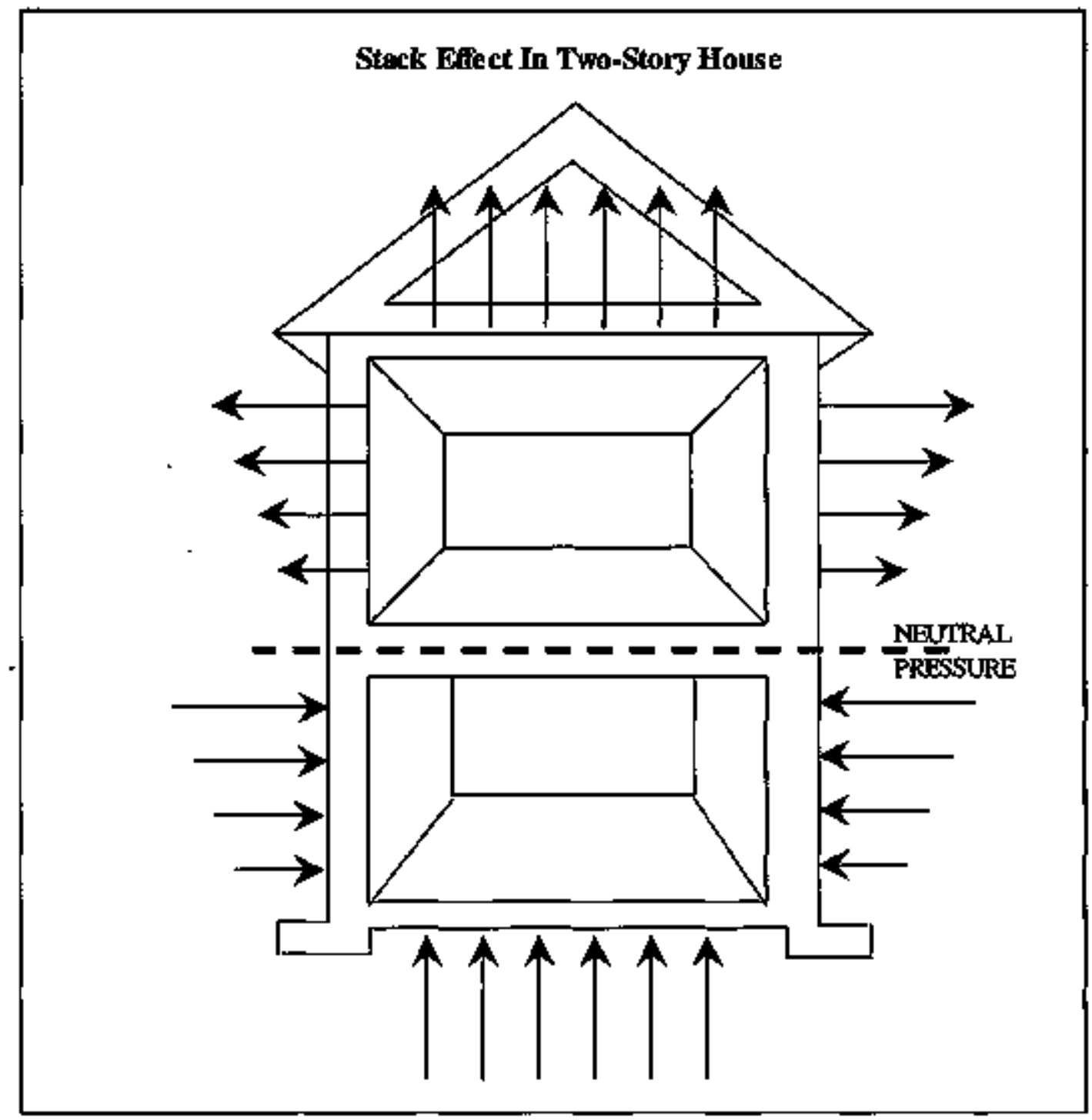

Very leaky houses are uncomfortable and have high energy bills, so finding and curing infiltration problems is a high priority for weatherization operations. The rate of air infiltration in a home depends on many factors, the most important being the size and location of holes in the thermal envelope and the difference in temperature between inside and outside. Warm air inside a dwelling gives rise to "stack effect" infiltration as it tries to escape from the top of the envelope, sucking in cold air at tte bottom. Wind and leaks in duct systems can also have a major effect on infiltration, but these effects are not usually as constant over the heating season as is stack-effect infiltration, which is at its worst on coldest days.

Note that in the middle of the heated envelope there is a neutral pressure zone where neither infiltration nor exfiltration occurs due to stack effect. This explains why caulking and weatherstripping in mid-envelope tends to save less energy than careful attention to the bottom and top of the envelope, where these natural driving forces are greater. 


\section{E. Conclusions from the 1996 Metaevaluation}

Benefit/Cost Ratio for Gas-Heated

Drellings in 1989 and 1996

\begin{tabular}{|c|c|c|}
\hline PERSPECTIE & BENETIS INCLUDED & COSIS INCLUDED \\
\hline \multirow{3}{*}{$\begin{array}{l}3 \\
3 \\
8 \\
8 \\
8\end{array}$} & $\begin{array}{c}\text { Energy } \\
\text { Savtsy } \\
\text { OnIy }\end{array}$ & $\begin{array}{l}\text { All } \\
\text { Costs }\end{array}$ \\
\hline & \multicolumn{2}{|c|}{$\begin{array}{l}1989 \text { Benefit/Cost Ratio }=1.06 \\
1996 \text { Benefit/Cost Ratio }=1.79\end{array}$} \\
\hline & BENDFIIS INCLUDED & CosTS INCLUDED \\
\hline \multirow{2}{*}{ 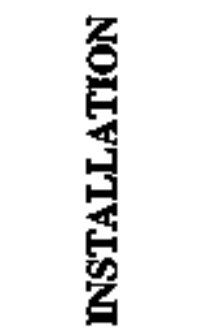 } & $\begin{array}{c}\text { Energy } \\
\text { Sayings } \\
\text { Only }\end{array}$ & $\begin{array}{l}\text { On-Site } \\
\text { Installation } \\
\text { Costs }\end{array}$ \\
\hline & \multicolumn{2}{|c|}{$\begin{array}{l}\text { J989 Benefit/Cost Ratio }=1.58 \\
1996 \text { BenefitKost Ratio }=2.39\end{array}$} \\
\hline \multirow{3}{*}{ 吕 } & BENEHLS INCLUDED & \begin{tabular}{|l|l} 
CosTS ANCLUDE \\
\end{tabular} \\
\hline & $\begin{array}{c}\text { Botg } \\
\text { Energy and } \\
\text { Nontenergy Benefits }\end{array}$ & $\begin{array}{l}\text { All } \\
\text { Costs }\end{array}$ \\
\hline & \multicolumn{2}{|c|}{$\begin{array}{l}1989 \text { BebefitiCost Raxio }=1.61 \\
1996 \text { Benefit } / \text { Cost Ratio }=2.40\end{array}$} \\
\hline
\end{tabular}

All aspects of the Metaevaluation point to inproved performance during the past seven years. In spite of funding reductions, technical advances have produced $80 \%$ higher energy savings on a per dwelling hasis. Increases in energy savings were achieved through better training, andit tools, and management practices with little increase in costs. The trend toward increased savings was demonstrated in three ways:

"regression modeling results obtained from a metrevaluation of 17 stateleve] ovaluations;

"comparisons of a 1950 and a 1996 literature review of state-level evaluations; and

comparisons of within state savings over time.

Each of these approaches pointed to significant increases in Program energy savings. As a result, Program benefit/cost ratios are even higher today than they were in 1989, with a 1996 societal benefit/cost ratio of 2.40 .

The DOE will continue to monitor on-going state-level evaluation efforts and will conduct several cooperative state-level evaluations in the next few years. Results of additional state-level evaluations will be incorporated into the metaevaluation framework as they become available. Periodically updated metaevaluation results will be used to track Progrart perfortinance.

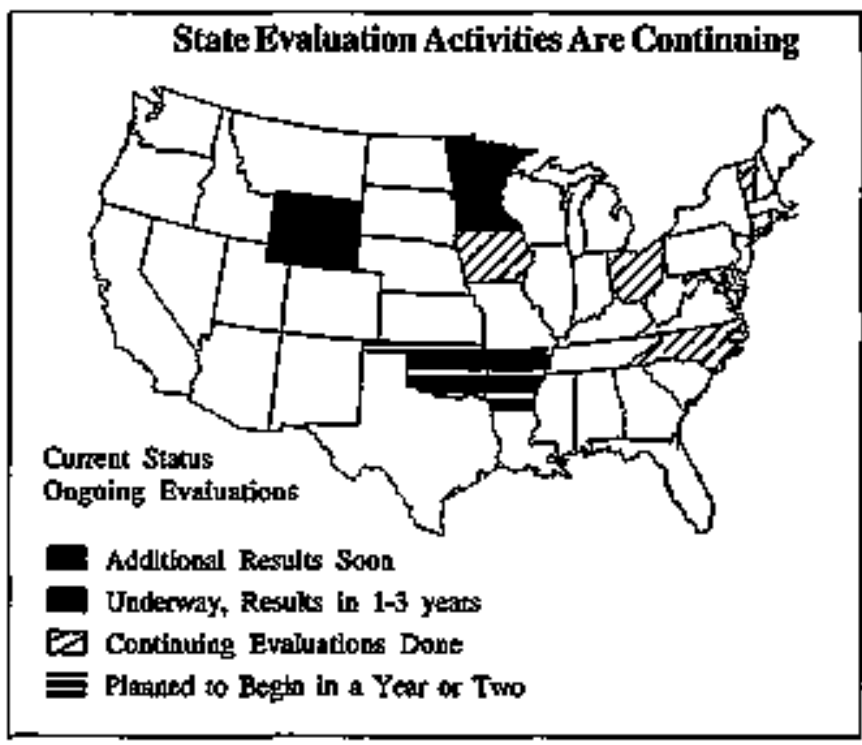




\section{Housing Rehabilitation}

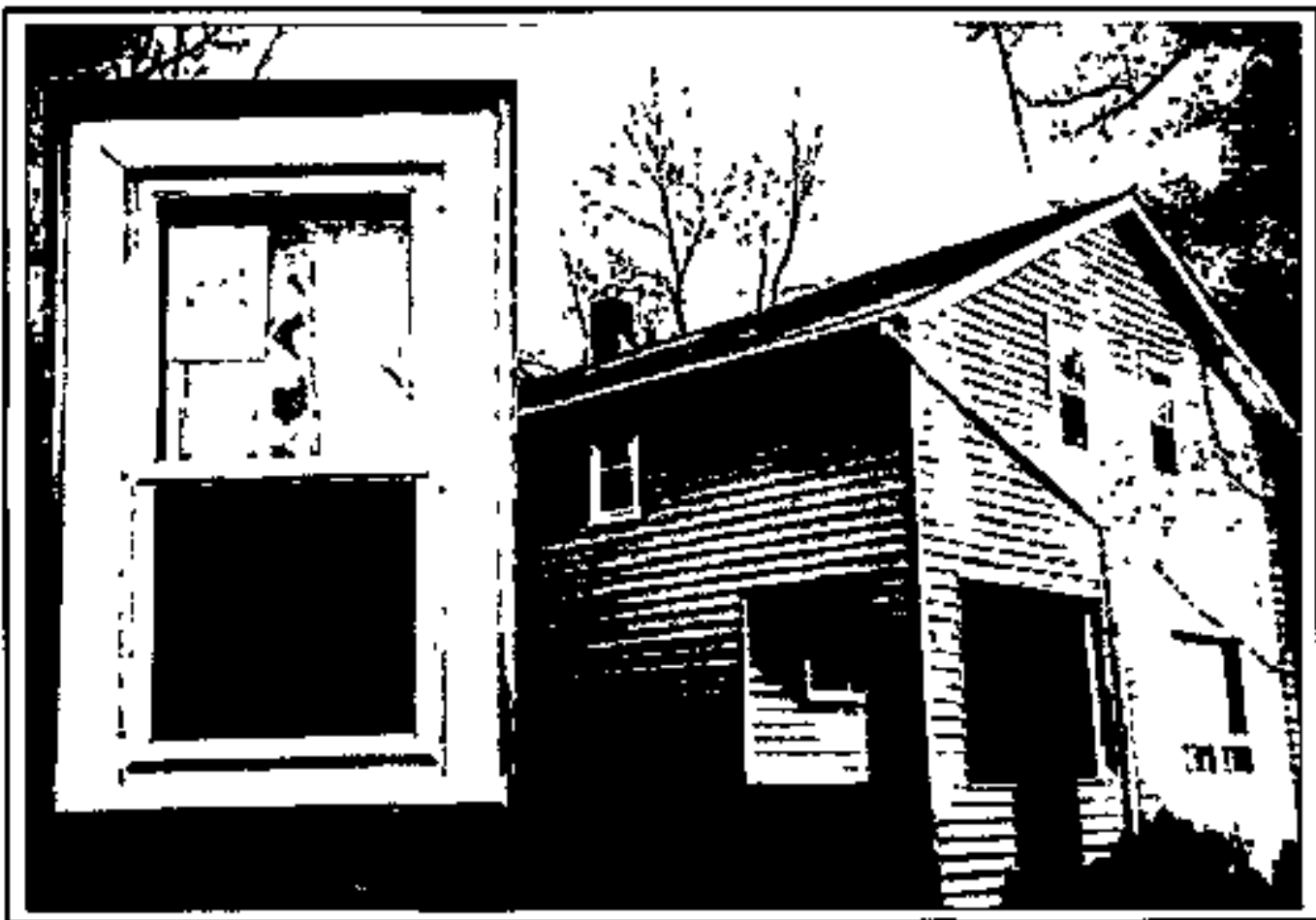

This rehabsiltated home had new windows installed with HUD funds, and insulation installed with DOEfunds.

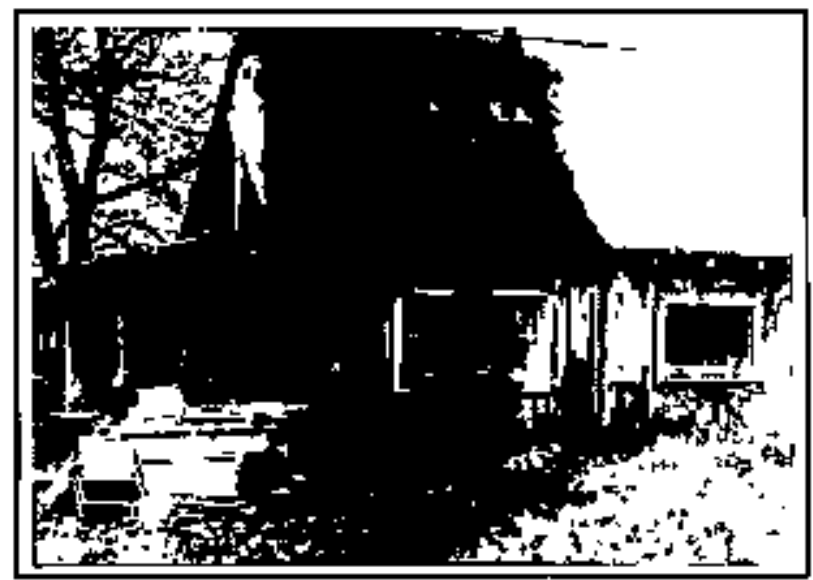

Before Weatherixation

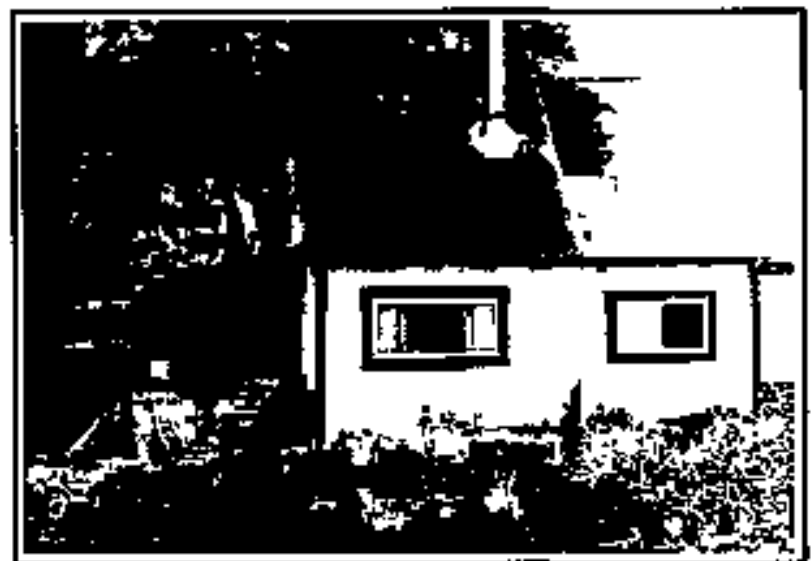

After Weatherkation
This dilapidated home which received an impressive retrofit is one example of the substandard housing local agencies often serve. Holes in roofs, walls, and ceilings, and broken windows are common problems. Leveraged funds from non-DOE soutces are often tused to meet housing reliabilitation needs. 


\section{NATIONAL EVALUATION METHODS AND RESULTS FOR 1989}

\section{A. National Evaluation Process and Publications}

The National Weatherization Evaluation was a comprehensive evaluation of the Weatherization Assistance Program, which was designed to accomplish the following goals:

- estinate energy savings and cost effectiveness;

- assess nonenergy impacts;

- describe the weatherization network;

- characterize the eligible population and resources; and

- identify factors influencing outcomes and opportunities for the future.

The National Weatherization Evalnation's Three Climale Region

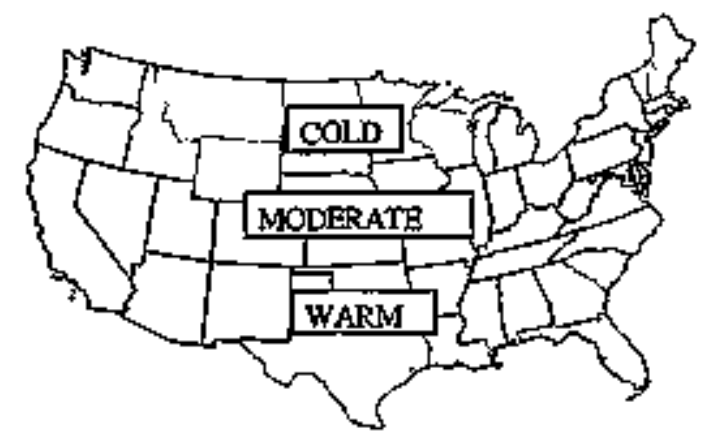

$\square$ Cold

Moderate

Warm
Working groups with more than $\mathbf{3 0}$ nationally known evaluation specialists and conservation program professionals were formed to help define these goals. They gave guidance to the ORNL evaluation team in planning five major studies and in reviewing draft reports. The five studies were as follows:

Single-Family Study-this study estimated the national savings and cost effectiveness of weatherizing singlefamily and small multifamily dwellings that use natural gas or electricity for space heating.

Fuel-Oil Study-athis study estimated the savings and cost effectiveness of weatherizing single-family homes in nine northeastem states that use fuel oil for space heating.

Multfamily Study-this study described the measures used, resources employed, and challenges faced in weatherizing large multifamily buildings.

Network Study--this study characterized the weatherization network's leveraging, capabilities, procedures, statf, technologies, and innovations.

Resources and Population Study--this study profiled Jawincome weatherization resources, the weatherized population, and the population remaining to be served. 


\section{DENSE-PACK CEILULOSE}

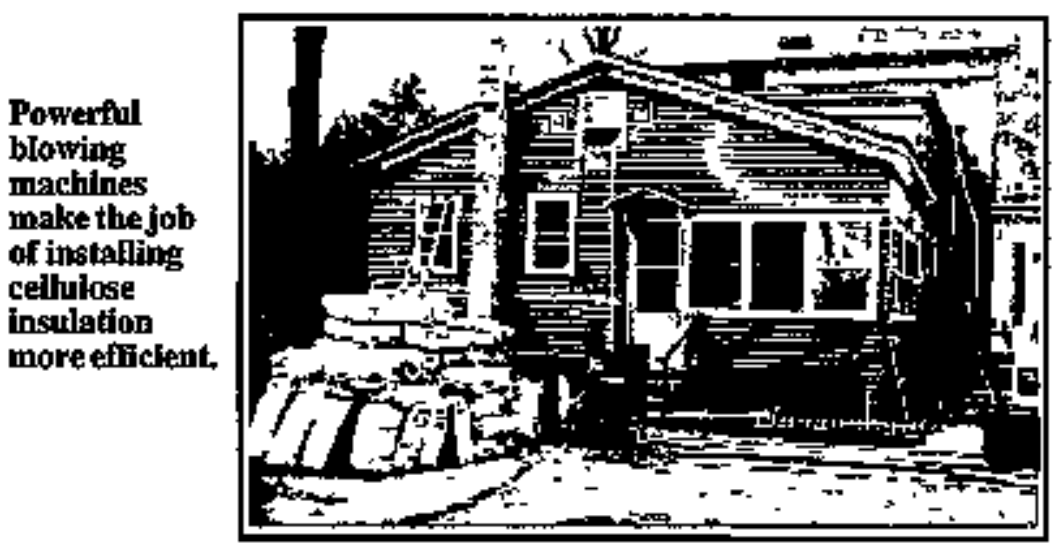

Installing cellulose at high density has been found to be a poweriol technique for installing insulation and achieving air sealing at the same time. Many crews find that the infiltration rates of some houses can be cut in half without using a tube of caulk. The secret is careful installation of highdensity cellulose in wall cavities (and other places where it really counts) with a tube inserted directly where the insulation needs to go-and using power blowing machines to pack it in tightly.
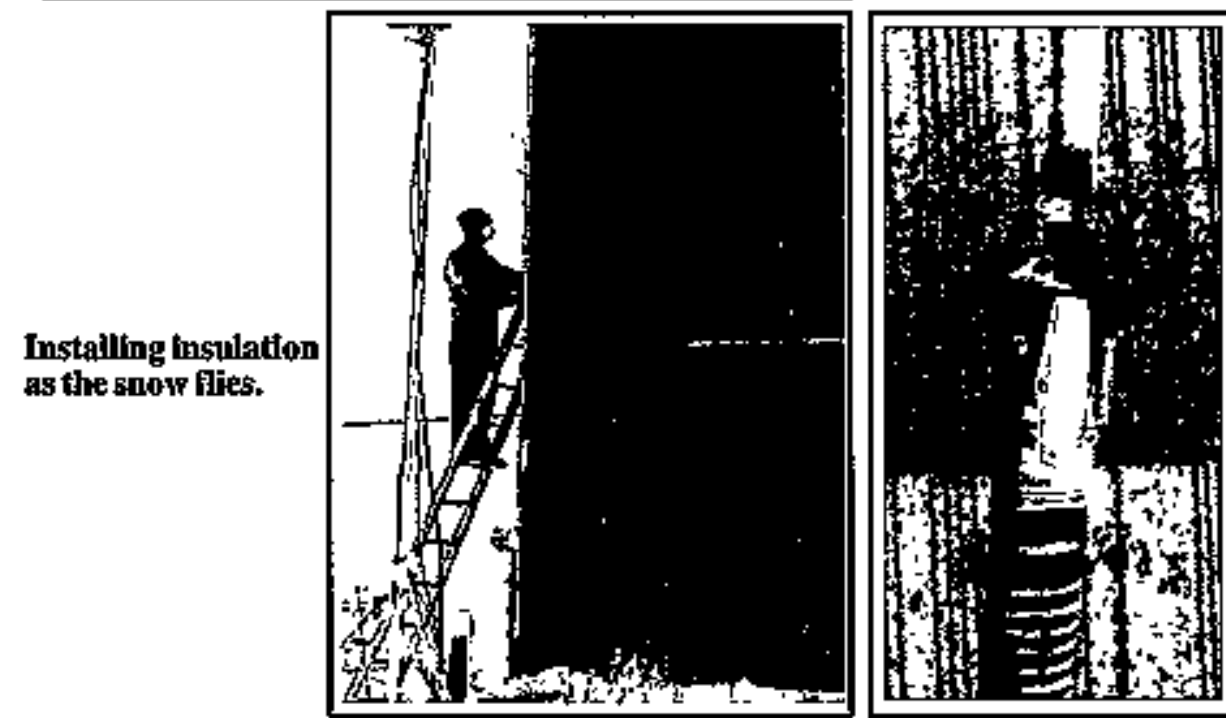

The small tube at the top is snaked into wall carities, then slowly withdrawn as insulation fills them up. The result is a very tight fill.

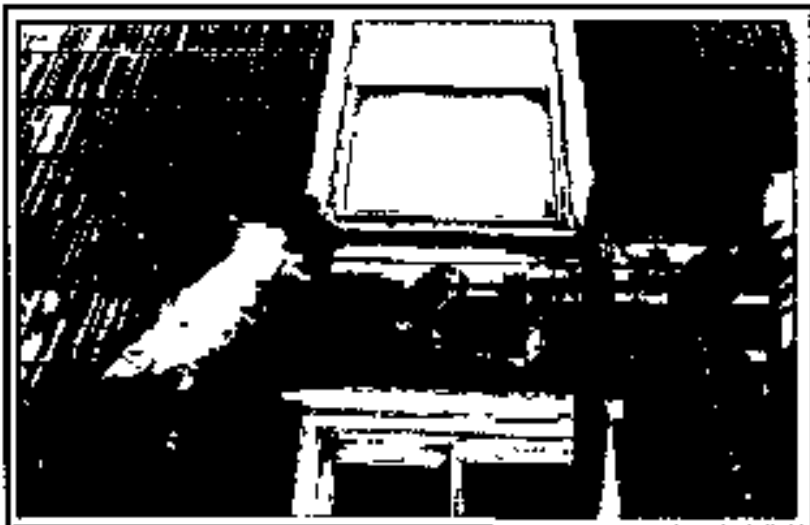

Preparation, insulation, and cleanup keeps two weatherlzation team members working for most of a day.

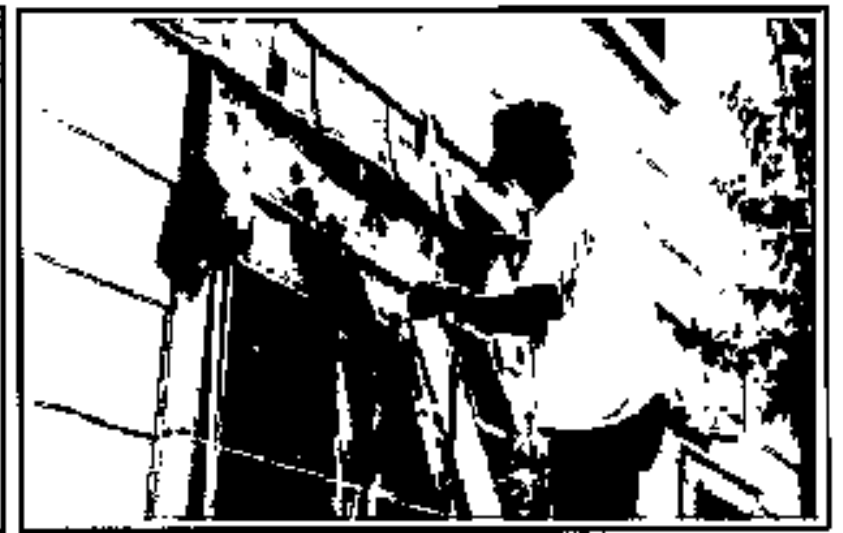

Wall preparation. Shingles are positioned for fast reattachuent after insulation blowing. 


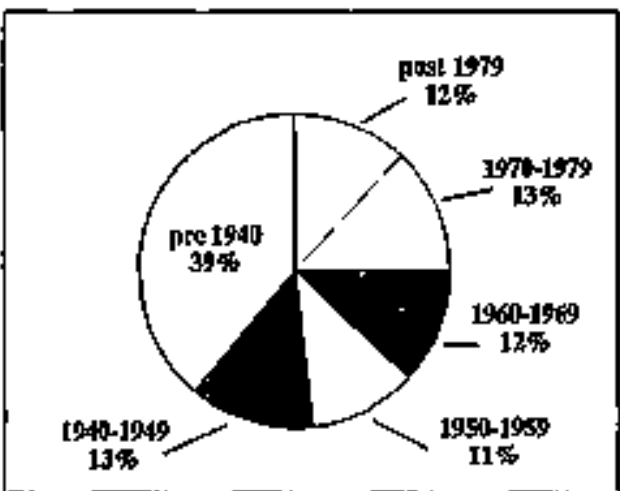

Year of Construction of Dwellings Weatherized in 1989

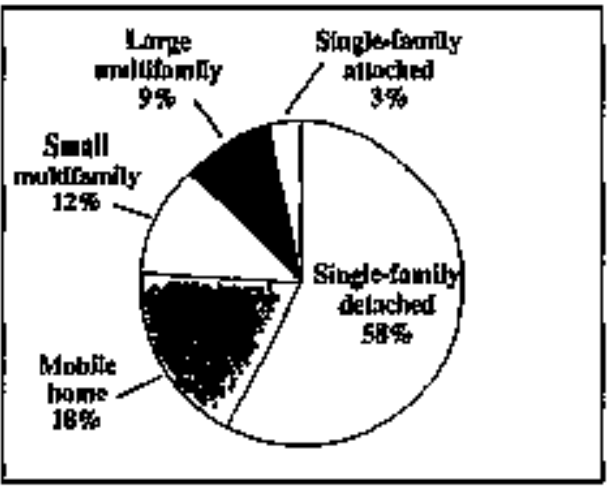

Types of Dwellings Weatherized in 1989
The findings from each of these studies were documented in a series of eleven reports published between 1990 and 1994. References to these reports are at the end of this document.

\section{B. Dversity of Dwellings and Agencies}

Perhaps the most striking finding of the comprehensive National Evaluation was the diversity anong local weatherization agencies across the country. Some agencies weatherized 15 homes in a year; others weatherized thousands. Some agencies achieved savings of 30 to 40 percent of pre-weatherization consumption. Others produced no measurable savings. Some agencies employed state-of-the-art procedures, used a variety of funding and techrical resources, and peformed sophisticated self-evaluations. Others followed the stime procedures year after year, did not evaluate their impacts, and relied entirely on DOE for funding. With the downsizing of the Program in the last few years, many areas previousily served by the smaller agencies have been incorporated into larger agency service areas.

The housing stock addressed by the Program also is diverse. Most low-income people live in homes built when energy was not an expensive commodity. Poor insulation and leaky construction bave wasted energy from the start, and, inevitably, aging makes structures more energy inefficient, more expensive to heat, and often cold, unsafe, and unhealthy. Among the dwellings weatherized in 1989, 39 percent were more than 50 years old. On the other hand, only 12 percent were less than 10 years old.

Dwellings can be classified into five types. Each type has unique weatherization needs.

Single-family detached homes were the dominant type of structure weatherized by the Program in 1989 (representing 58 percent of the total). Half of these single-family detached units heated primarily with natrral gas, and only 10 percent hezted with electricity. Elderly occupants resided in 40 percent of these houses, a higher concentration than for any other dwelling type. The vast majority of these houses (73 percent) were owner-occupied.

Single-family attached dwellings (often called row houses) comprised the smallest housing-type category ( 3 percent of the weatberized population). Almost all were centraIly heated (93 percent). As a class, these were the oldest buildings, with a mean age of 56 years. They also tended to have higher-income occupants and were located almost entirely in the moderate region.

Moblle homes comprised 18 percent of the weatherized population. They were by far the "newest" units, with an average age of only 17 years. These homes were more likely than any other housing to be heated with a nonmetered fuel (mainly propane) and were 78 percent owner-occupied. Mobile homes were occupied by individuals with the lowest incomes. 
Net average annual energy savings (by fuel type) per dwelling for dwellings weatherized in 1989 (based on a billing analysis of a representative national sample of homes)

\section{Estimated average annutal savings per dwelling heated with natural} gas in 1996 (based on a regression model developed from 17 state-Levet evaluations of natural gas savings conducted between 1990 and 1995)

\begin{tabular}{|c|c|c|c|}
\hline Primary heating fuel & $\begin{array}{l}\text { Percent of } \\
\text { space heating } \\
\text { consumption }\end{array}$ & $\begin{array}{l}\text { Percent of } \\
\text { total fuel } \\
\text { consumption }\end{array}$ & $\begin{array}{l}\text { Net savings } \\
\text { (Mbtu/year) }\end{array}$ \\
\hline $\begin{array}{l}\text { Nanural gas } \\
1989 \text { National Evaluation } \\
\text { 1996 Metaeyaluation } \\
\text { (estinated from regression } \\
\text { model) }\end{array}$ & $\begin{array}{l}18.3 \% \\
33.5 \%\end{array}$ & $\begin{array}{l}13.0 \% \\
23.4 \%\end{array}$ & $\begin{array}{l}17.3 \mathrm{Mbtu} / \text { year } \\
31.2 \mathrm{Mbtu} / \text { year }\end{array}$ \\
\hline Electricity & $35.9 \%$ & $12.2 \%$ & $18.9 \mathrm{Mbtu} /$ year \\
\hline Fuel Oil (Northeast) & $17.7 \%$ & $17.7 \%$ & $22.4 \mathrm{Mbtu} /$ year \\
\hline All fuels* & $18.2 \%$ & $13.5 \%$ & $17.6 \mathrm{Mbn} /$ year \\
\hline
\end{tabular}




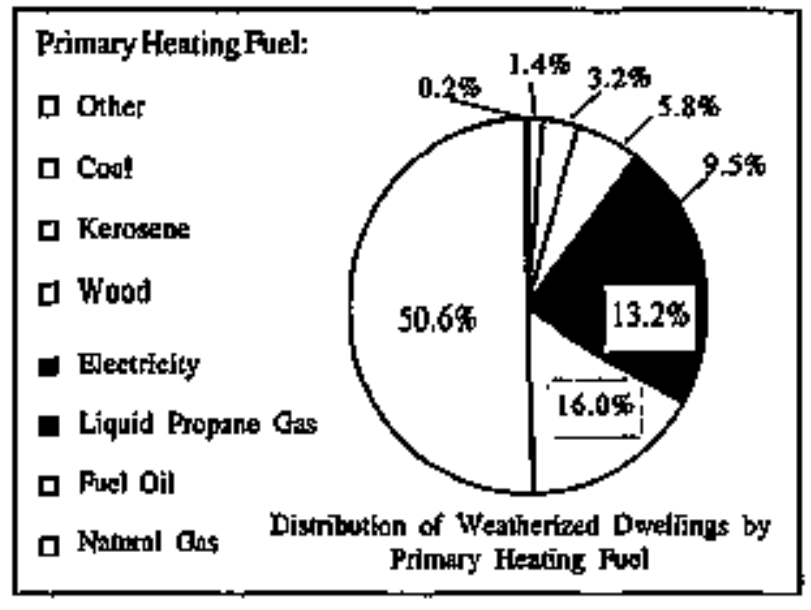

Small inultifamily dwellings (those located in buildings with 2 to 4 units) comprised 12 percent of the weatherized population. They were heated primarily with natural gas (73 percent) and were typically renter-occupied (82 percent). Compared to single-family detached homes, they were only half as likely to have an elderly on handicapped occupant.

Large multifamfly dwellings comprised 9 percent of the weatherized population and represented a distinct building type. They were located almost entirely in the moderate and cold regions (approximately half are located in New York City), and they tended to be older than the single-family dwellings weatherized by the Program (52 percent vs. 38 percent were built before 1940 ). This type of dwelling is, for the most part, centrally heated by gas, electricity, of fuel oil.

\section{Program Benefits}

\section{National Energy Savings in 1989}

\section{Equivalent 1989 S avings} In Barrels of 0il

\begin{tabular}{|lr|}
\hline per day & 1,650 \\
per year & 601,000 \\
20-year & 12 nillion \\
lifetime & \\
\hline
\end{tabular}

During Program Year (PY) 1989, the Program weatherized 198,000 stingle-family or small multifamily homes, restulting in net energy savings during the following year equivalent to 601,000 barrels of oil, or almost 1,650 barrels of oil per day, ${ }^{2}$ Over the estimgted 20-year lifetime of the weatherization measures, net savings from Program expenditures in 1989 are projected to be 69.7 trillion Btus, the energy equivalent of 12 million barrels of oil. These estimates are based on measured reductions in the use of primary heating fuels after weatherization. Savings of supplemental heating fiels were not measured.

Gas-heated dwellings accounted for 50 percent of the dwellings weatherized by the Program in 1989. It is estimated that the Prograrn, which addresses only space heating and sometimes water heating energy efficiency, saved 18.3 percent of the gas used for space heating. This represented 13.0 percent of total gas use, including water heating, cooking, and other gas-appliance uses. Variations in savings by dwelling type were significant. For example, single-family detached dwellings (the dominant dwelling type served by the Program) saved over 50 percent more natural gas per dwelling than did mobile homes.

Electrically heated homes represented only 10 percent of the dwellings weatherized under the Program during 1989. Weatherization of these dwellings saved 35.9 percent of the electricity used for space heating. This represented 12.2 percent of total electricity use. As with gas-heated homes, both single-family detached and small multifamily dwellings saved more electricity than did mobile homes.

${ }^{2}$ A barrel of oil is equal to 42 U.S. gallons and represented approxinately two weeks of petroleum consumption per Americon in 1990. The equivalent aumber of barrel(s) of oil is, of course, a concrete way of expressing the 3,370 billion British thermal units (Btus) saved during 1990 due to weatherization wojk on single-fanily dwellings during Program Year 1989. In reality, of course, the savings occurred not only in gallons of oil, but also in hundreds of cubic feet (cef) of natural gas, kilowalthours (kWh) of electricity, and other units of wuel. Where electricity is concemed, savings reported include the energy required to generate electricity at fts source. 


\begin{tabular}{|l|c|}
\hline \multicolumn{1}{|c|}{ Type of nonenergy impact } & $\begin{array}{c}\text { Value of the impact } \\
\text { per dwwelling }\end{array}$ \\
\hline Encreased property value & $\$ 126$ \\
\hline Reduced incidence of fire & $\$ 3$ \\
\hline Reduced arrearages & $\$ 32$ \\
\hline Eederal taxes generated from direct employment & $\$ 55$ \\
\hline Income generated from indirect emplovment & $\$ 506$ \\
\hline Avoided costs of unemployment benefits & $\$ 82$ \\
\hline Environmental externalities - & $\$ 172$ \\
\hline Total & $\$ 976$ \\
\hline
\end{tabular}

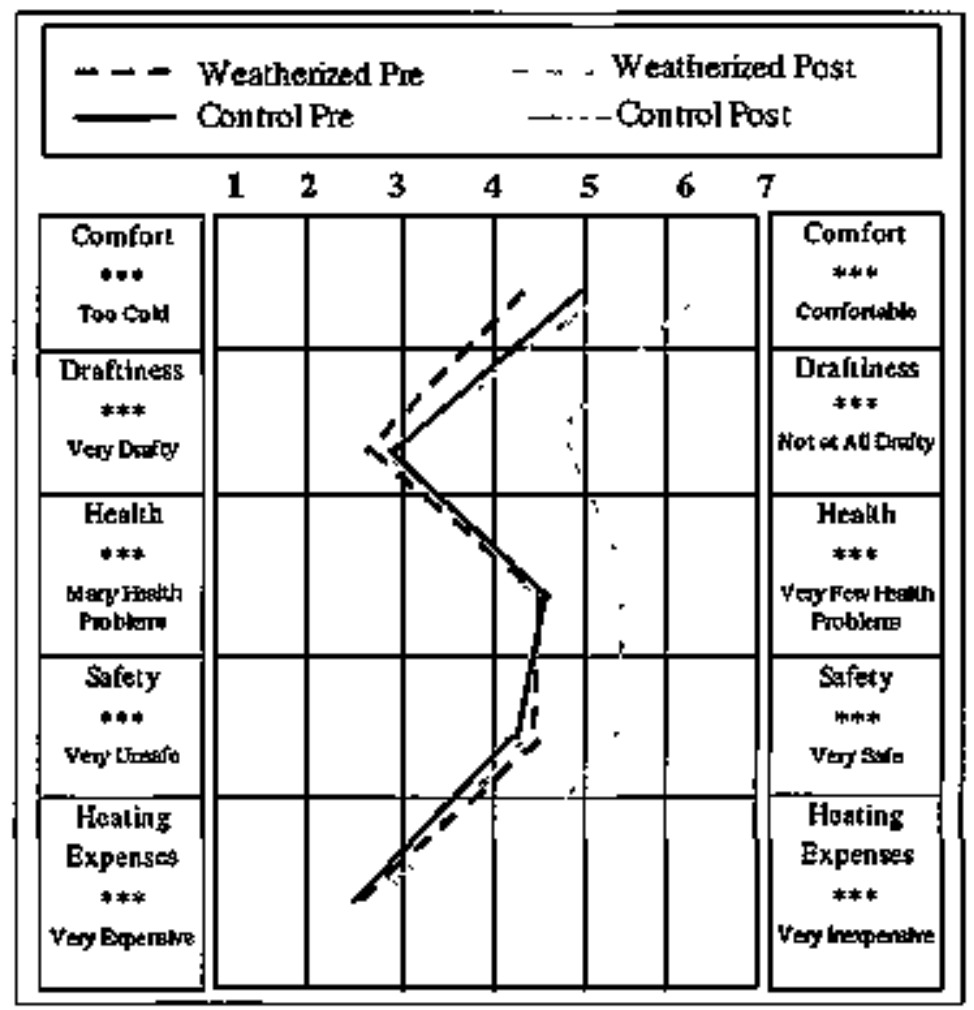

Occupant Perteptions of Nonenergy Beneffts of Weathertzation in Weatherized and Control Dwellings 
The Fuel-Oil Study showed that an average single-family dwelling located in the Northeast and heated primarily by fuel oil saved 160 gallons of fuel oil in the first year following weatherization. This is equivalent to 22.4 million Bbus, or $\mathbf{1 7 . 7}$ percent of total fuel-oil use. (Fuet oil is generally used only for space heating.)

Measared savings for gas, electricity, and fuel oil were combined with estimates of energy savings for dwellings that heated primarily with other fuels such as propane, wood, kerosene, and coal. The average savings for all single-family and small multifamily dwellings weatherized in 1989 was estimated to be 17.6 million Bus per year, 18.2 percent of the energy used for space heating and 13.5 percent of totai energy use.

\section{Nonenergy Benefits}

The Program's weatherization activities have numerous benefits beyond reductions in energy consumption. Improvements to dwellings often raise the health, safety and confort levels of eccupants as well as increase the value of their homes. Reducing energy demand decreases the environmental impacts of energy production. In addition, lowering energy consumption produces a variety of economic benefits such as reduced energy burdens, more funds for other expenditures, and jircreased employment. In this section, information on selected nonenergy benefits is discalssed.

Occupants' perceptions of the health, safety and comfort of their homes were much improved after weatherization. Occuparts of weatherized and control homes were asked to rate the

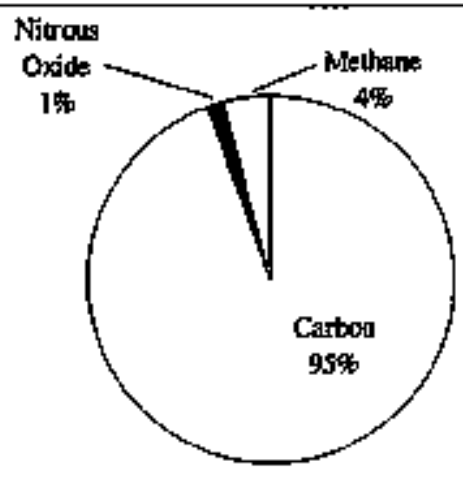

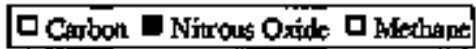

Climate chango eccuivalent emlssion reductions of 19 s' Program, hy type of greenhouse gas. confort, draftiness, safety, and heating expenses for their homes. They also were asked to rate their own health (in terms of the incidence of illnesses, such as colds, flu, allergies, headaches, nausea, arthritis, which nuay be affected by the temperature, $C O$ levels, or draftiness of the dwelling).

On every rating scale the weatherized group reported a highly significant and positive change after weatherization was completed. The control group, on the other hand, reported no change in any of the ratings. Thus, the weatherization clients experienced improvements in the comfort and safety of their homes, while the control group did not. The weatherized group also believed their homes became less drafty and their heating bills more affordable after weatherization. The control reported no changes. Finally, the weatherized group believed that there had been an improvement in their own health, while the control group fid not. Although it is difficult to place a monetary value on these health, safety, and comfort benefits, occupants of weatherized dwellings recognize and appreciate them.

Envirommental benefits from weatherization include the reduction of greenhouse gas emissions. The principal gases of concern from the perspective of global warming are carbon dioxide $\left(\mathrm{CO}_{2}\right)$, methane $\left(\mathrm{CH}_{4}\right)$. and nitrous oxide $\left(\mathrm{N}_{2} \mathrm{O}\right)$. The following calculations are based on dwellings weatherized in 1989 that heated printarily with electricity, natural gas, fuel oil, LPG, or kerosene. 


\section{HEALTH AND SAFETY}

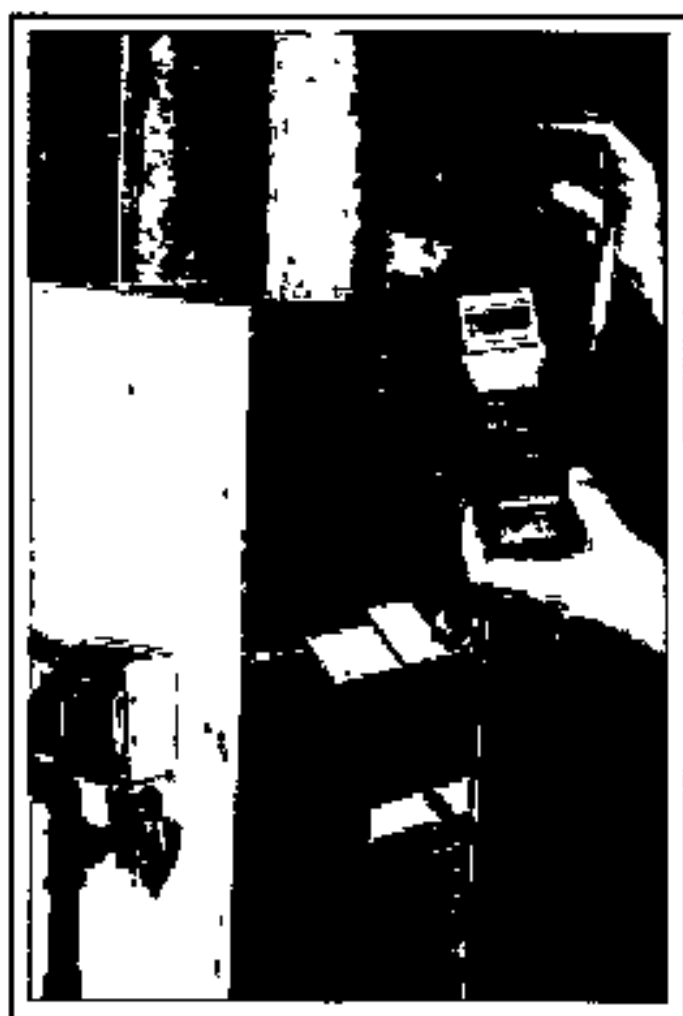

Testing for carbon monoxlde ensures both furpace efficiency and safety.

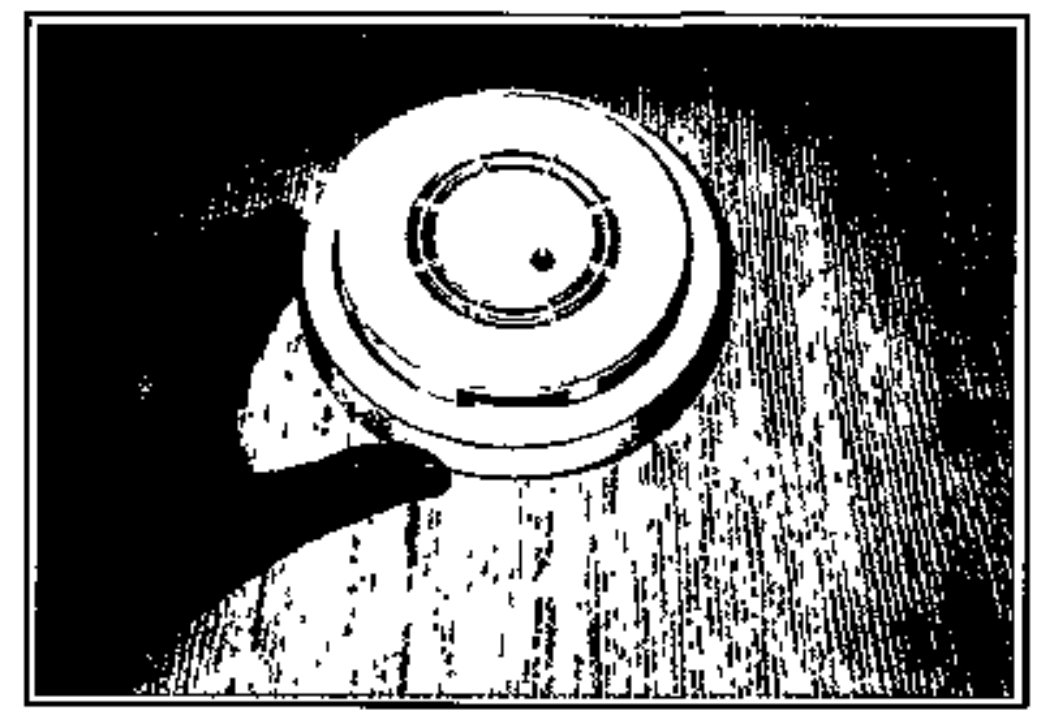

Smoke alarm installations improve safety.

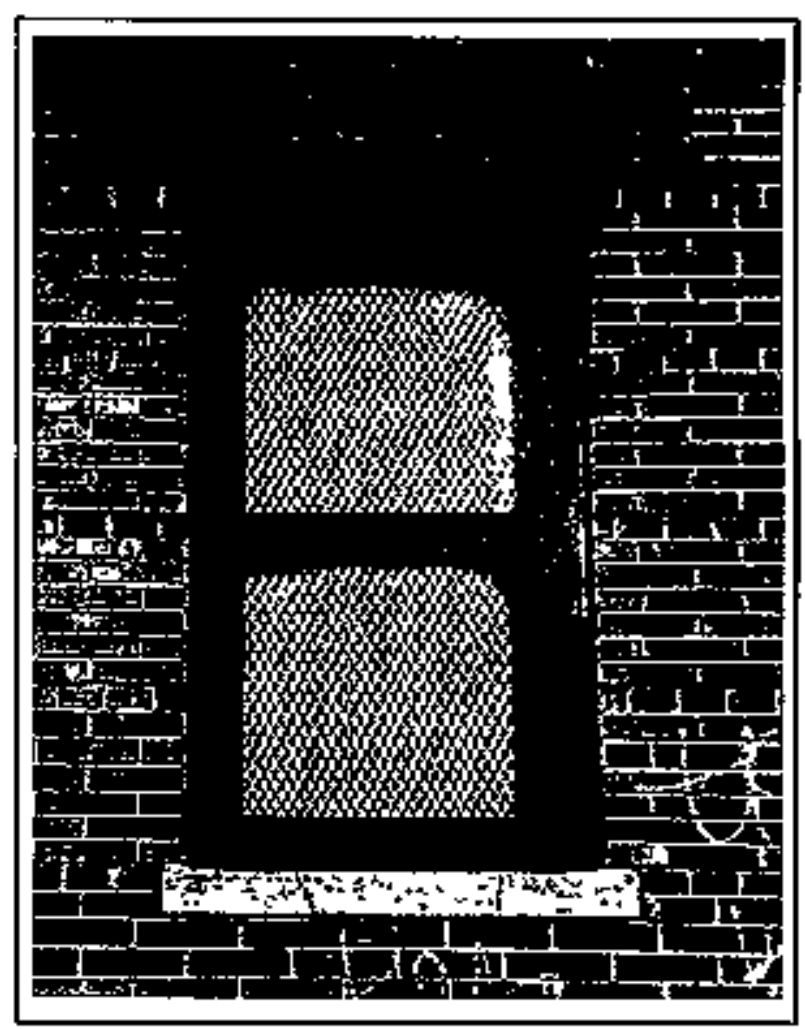

Some weatherlzation crews install security meensures on first-story windows.

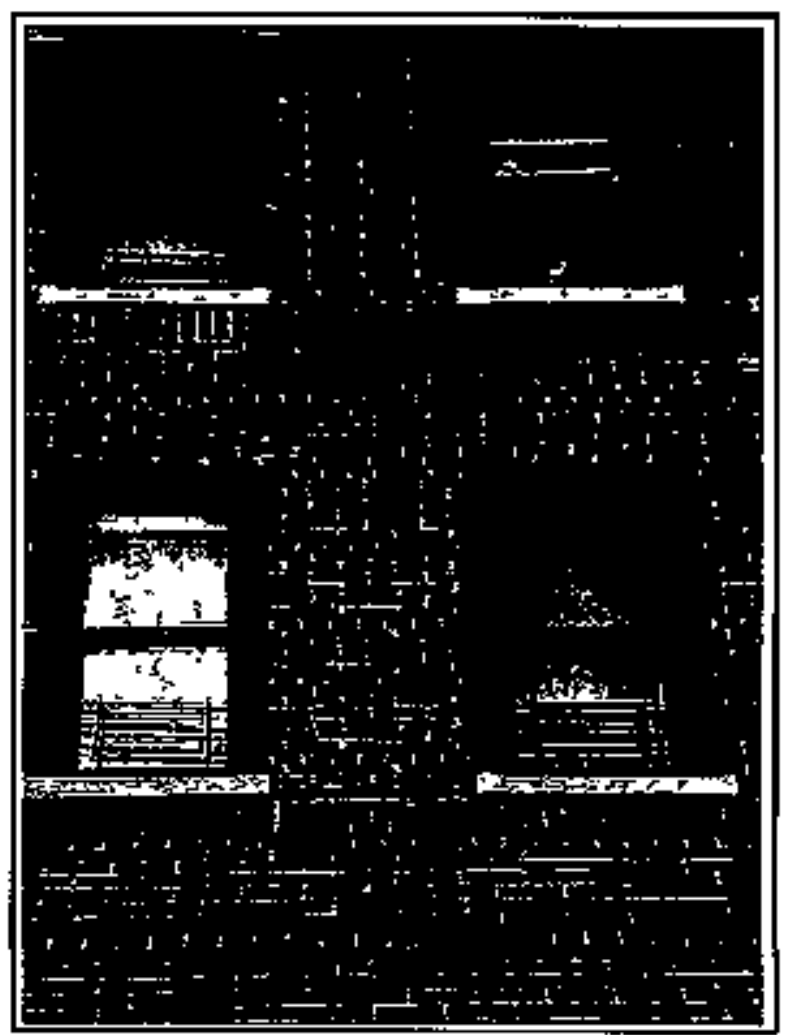

Higher-level windows recelve grates to promote child safety. 
Weatherizing a dwelling that heats primarily with natural gas reduces carbon emissions by 0.2489 metric tons per year. Weatherizing a dwelling heating with electricity reduces catbon emissions by 0.475 metric tons per year, assuming that emissions from electricity generation are equivalent to those from bituminous coal combustion. The carbon emission reductions per dwelling unit for fuel oil, LPG, and kerosene are $0.445,0.263$, and 0.306 metric tons of carbon, respectively. These estinates translate into $\mathrm{CO}_{2}$ entissions 3.67 times higher becatse of the additional weight of the two oxygen atoms.

Methane has 35 times the warming potential of $\mathrm{CO}_{2}$. If the entire cycle of production, transmission, distribution, and household end-tuse is included, a typical weatherized dwelling heated primarily with natural gas will reduce methane emissions (in $\mathrm{CO}_{2}$ equivalents) by 0.090 metric tons per year. The emission reductions from the other types of heating fuels are much smaller.

Electricity generation is the only source of nitrous oxfde emissions that is relevant to home heating. Weatherization yiejds an annual reduction in $\mathrm{N}_{2} \mathrm{O}$ emissions of 0.173 metric tons

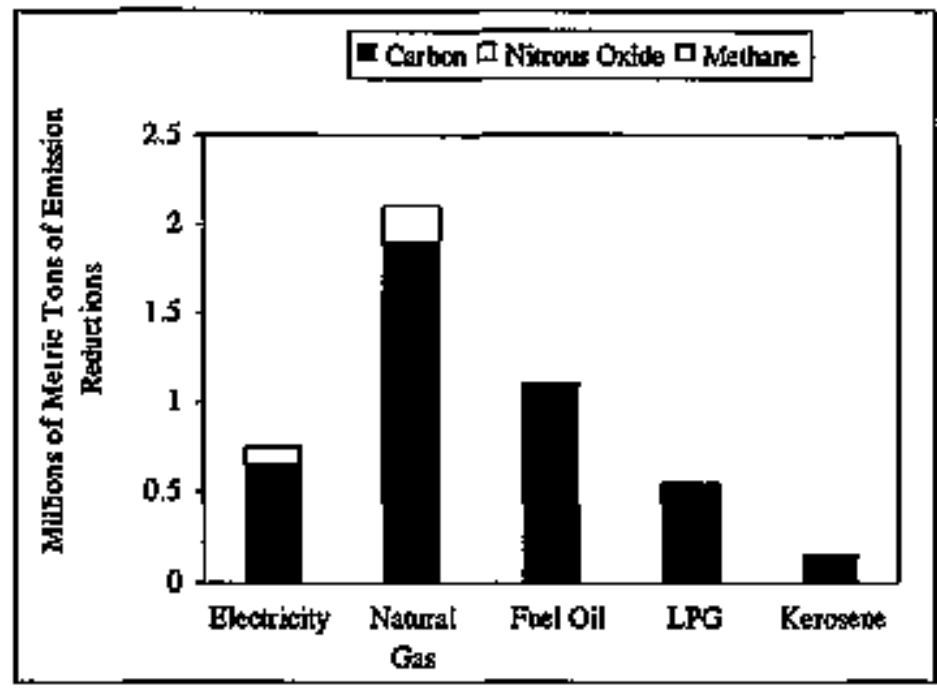

Cllmate thange equivilent entsston redretions of all houses weatherized by the progran in 1989 ower the 20-year Iffetime of the measurea, by type of hetation foel per electrically heated dwelling, in $\mathrm{CO}_{2}$ equivalents.

The 1989 Program as a whole reduced the equivalent of more than 4 million metric tons of $\mathrm{CO}_{2}$ over the 20 year lifetime of the measures in the 198,000 weathenized homes. The amount of $\mathrm{CO}_{2}-$ equivalent emission reductions due to various types of heating fuels and greenhouses gases are shown in the figure on this page. Since most of the dwellings weatherized by the 1989 Program were heated primarily with natural gas, these dwellings are responsible for the biggest share of the $\mathrm{CO}_{2}$-equivalent reductions. They are also the only dwellings with a measusable methame impact. Carbon reductions account for the vast majority of the Weatherization Program's reductions of $\mathrm{CO}_{2}$-equivalent greenhouse gas enissions. The next largest greenhouse gas inpacted by the Program is methane.

The value of nonenergy benefits is often difficult to quantify. For the purposes of the evaluation, selected nonenergy benefits were assigned a dollar value, but the methods used to estimate their value varied. 


\section{SINGLE-FAMILY DETACHED HOMES ARE FIFTY-EIGHT PERCENT OF TOTAL DWELEINGS WEATHERIZED}

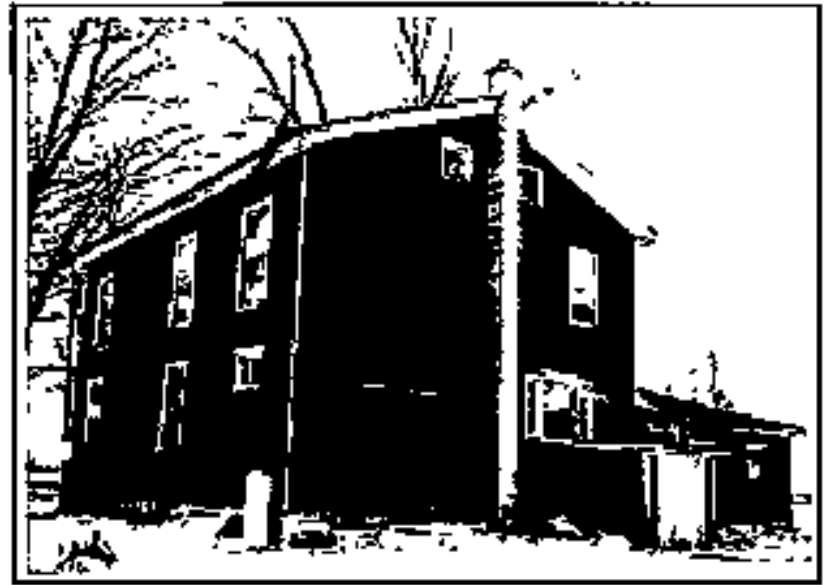

This farmbouse saved over 50 percent by air sealing, wall insulation, and furnace replacement.

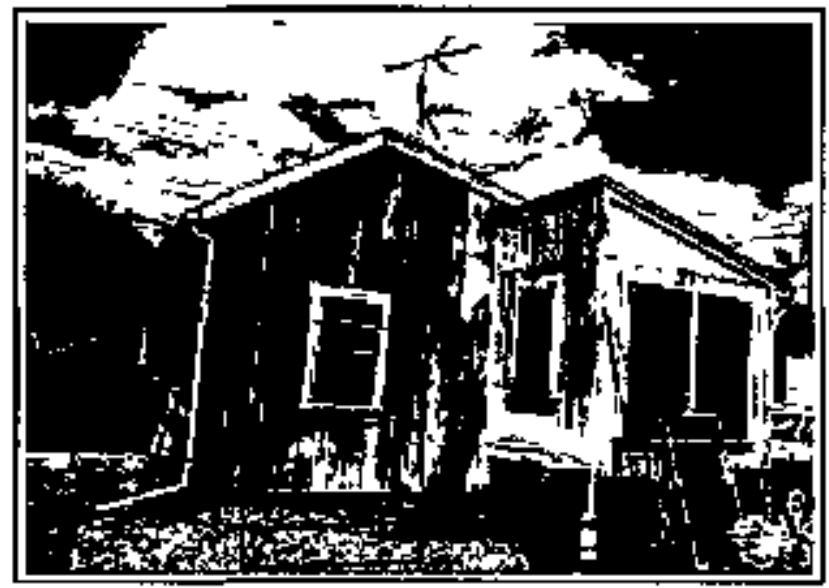

Joining the new to the old often causes trouble.

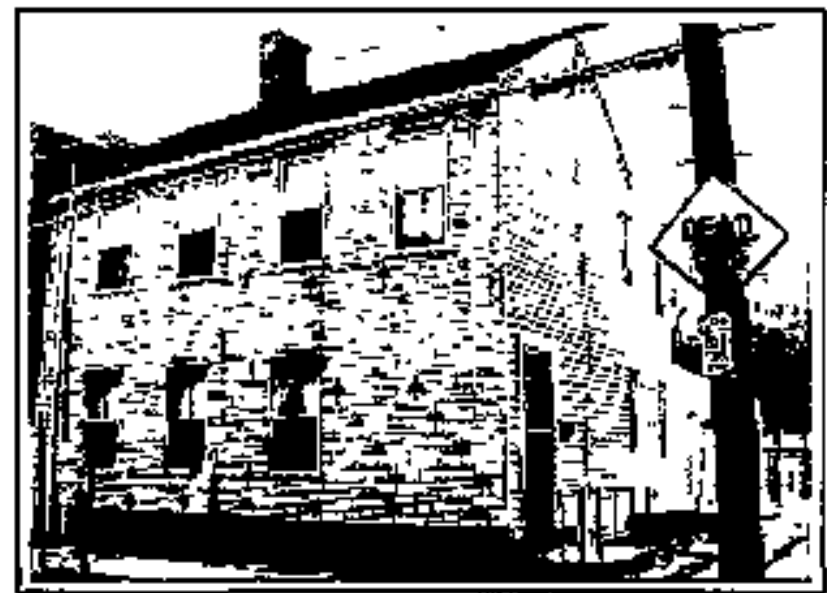

Retrofit siding hides majior holes that cause air leakage.

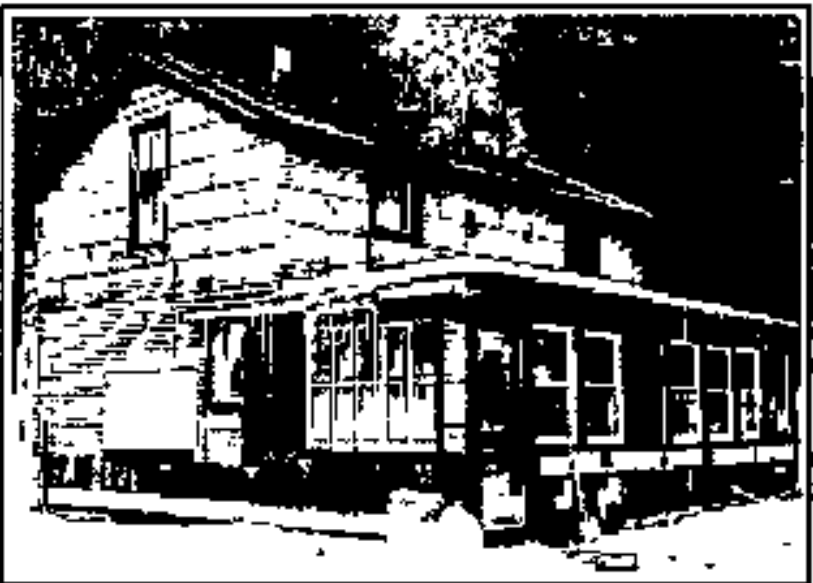

An uninsulated attic and air leakage between the perch and main structure are the main energy problems with this dwelling.

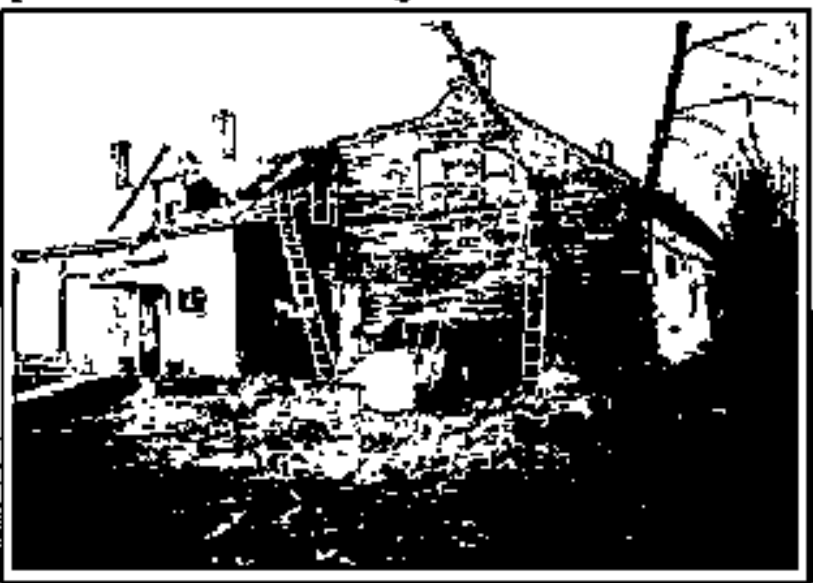

Movement of deteriorated foundation walls has opened large paths for air leakage-

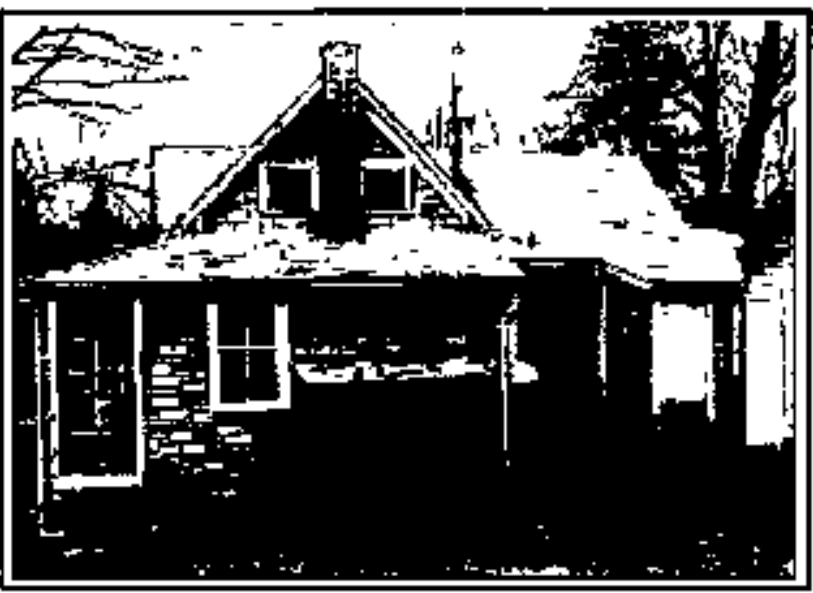

Built in sections over many years, this dwelling has major leaks between the main house and newer additions. 
Estimates of environmental benefits relied on a literature review and on information about the proportions of weatherized dwellings using various fuel types and the average savings of different fuels. Estimates of employment benefits combined a literature review with data on Program employment, the skitI levels of workers, and managers' jutgments conceming the job market for weatherization workers, Data on Progran expenditures for horne repair were used to guantify the benefits associated with maintaining or enhancing property values and extending the lifetimes of dwellings. The monetary benefits of reducing the incidence of fires were quantified using insurance industry data. Estimates of reductions in arrearages were based on a literature review and data on payment histories collected on the dwellings included in the National Evaluation. For each

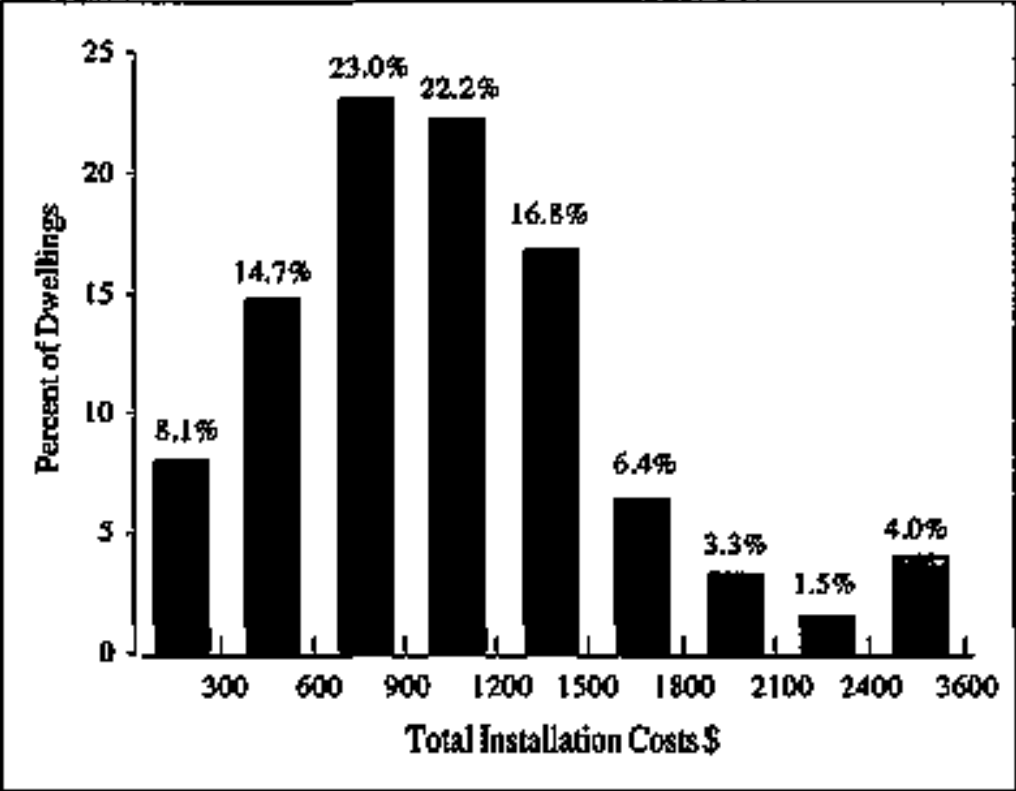

Installatlon Costs for Single-Fanily and Salall Multifamily Dwellings Weatherizad in 1959 benefit included in the estimate, we developed an average value per weatherized dwelling.

Ultirnately, the dollar value of nonenergy benefits resulting from the weatherization of single-family and small multifamily dwellings was estimated to be $\$ 976$ per dwelling. The table on page 38 provides a summary of these nonenergy benefit estimates.

\section{Cost Effectiveness}

Cost effectiveness is a measure of how well a progran works. To assess the cost effectiveness of the Weatherization Assistance Program, the market value of energy savings (and in some cases other benefits) was compared to the cost of instalting the measures that produced them. Benefits and costs were discounted over the estimated life of the measures. Cost effectiveness was assessed only for single-family and srnall multifamily dwellings because estimates of program impacts were not available for large multifamily buildings, which comprised only 9 percent of the dwellings weatherized in 1989.

\section{Program Costs}

DOE regulations in 1989 required (subject to certain exceptions) that the average of all costs not exceed $\$ 1,600$ per house. When the weatherization wotk is supplemented by non-DOE funds, average costs may exceed $\$ 1,600$.

To provide a picture of costs that is reasonably consistent regardless of the sources of funds used, costs were grouped under two broad categories: (1) installation costs (i.e., labor and materials assignable to particular houses) and (2) overhead and management costs. Overhead and management costs include costs directly related to installation but not readily assignable to particular houses (e.g., vehicles, travel time, and field supervision), and program management (e.g., intake, inspections, training and general administration). 


\section{DISTROBETION SYSTEMS}

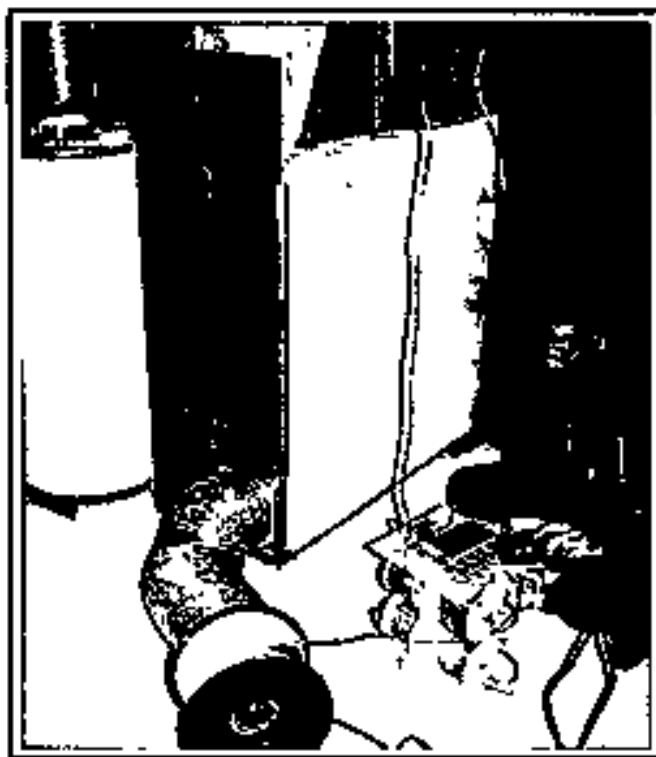

Theblowertoorandpressume-measariog gauges are useful bolh in quantifying dinct leakage asouclated whth dnct wonk andin revealing the locus of sgalif cant leaks. Protocols for using hoth blower dinows and thedistribution system'sownfan to quantify teaks arecurrentity being developed, and several companies have recenlly developed sunell carlorated blowers useful in leak detection and greality control to duct sealing.

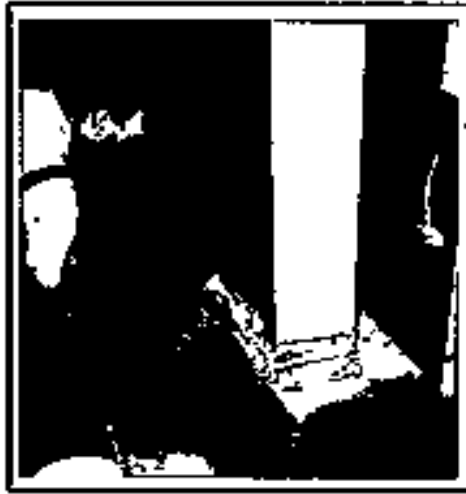

Permanent air sealing of the retorn air system is accom. plished with a flherolass mesh and special mastic.
Recent research has revealed that the distribution systems associated with central heating and air conditioning units are thernselves fiequentiy leaky. The combination of loose houses and large holes in return air systems results in inefficiency, unconfortable trafts, and high energy bills. The combination of tight houses and large holes in return air systems can cause backdrafting of the products of combustion from fumaces and hot water heaters, can dramatically ircrease the rate at which radon enters the dwelling-and can propel of these undesirable gases through the furnace's heat exchanger directly into the main part of the dwelling.

Duct problems can also negate the bersefits of other weatherization work. On the other hand, sealing and balancing duct systems can raise furnace system efficjency, lower overall air infiltration, solve moisture problems, entlance indoor air quality-and save energy.

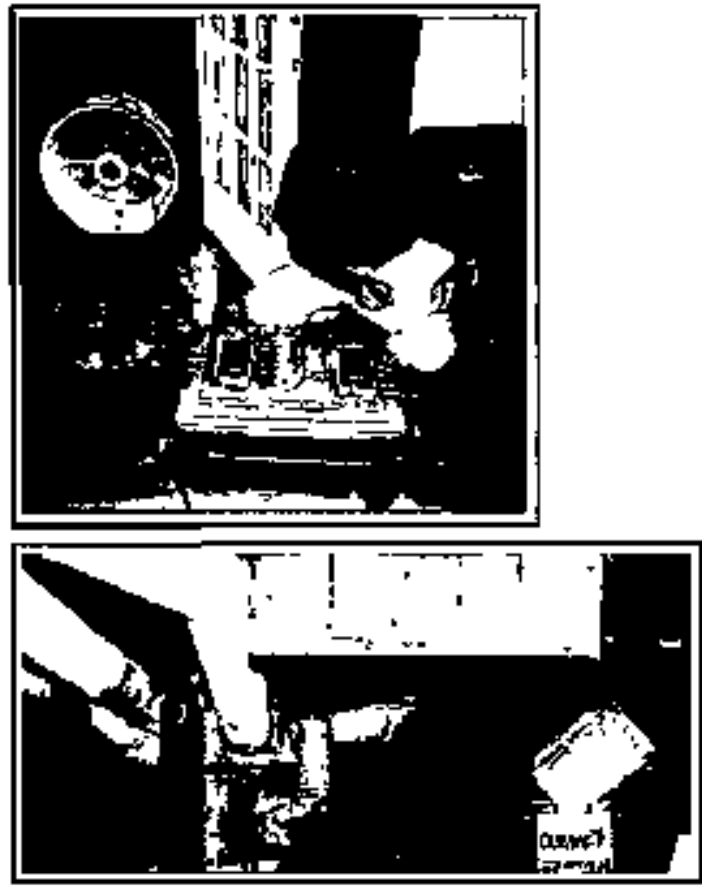

A woden return system on a gravity furnace is not only leaky but also inumediately adjacent to sindry volatile organic compounds. When the Amnace is ifired, fumes from these compaunds can be whisked fram the bassement into the living area.

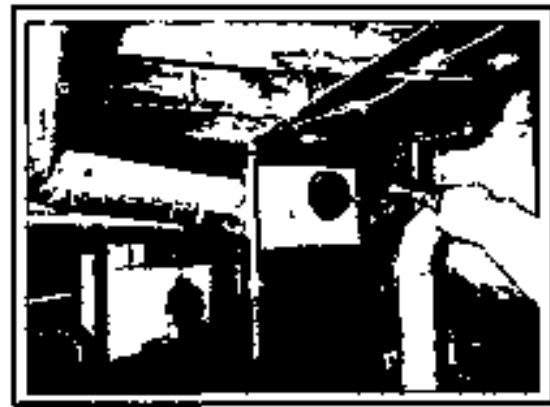

Holes like these in supply ductscan be quite wasteful-yet they can be repalred quickly and cost elifectively. 
Installation costs for single-family and small multifamily dwe]]ings weatherized in 1989 averaged $\$ 1,050$. For not quite half (45 percent) of the dwellings, these costs fell within the $\$ 600$ to $\$ 1,200$ range. The chart on page 43 shows the range of costs.

Because of variations in record keeping, it proved difficult to specify overhead and management costs with the same degree of precision as installation costs. After approaching the problem from several perspectives, the evalu-

\begin{tabular}{|c|c|c|}
\hline PFRSPQCTVK & BHNETISINCLIJPED & COSTS INCLIJDED \\
\hline \multirow{2}{*}{$\begin{array}{l}5 \\
\frac{5}{5} \\
8 \\
0\end{array}$} & $\begin{array}{l}\text { Energy } \\
\text { Savthes } \\
\text { Only }\end{array}$ & $\begin{array}{l}\text { All } \\
\text { Costs }\end{array}$ \\
\hline & \multicolumn{2}{|c|}{ Benefit Cost Ratio = 1.09} \\
\hline \multirow{3}{*}{ 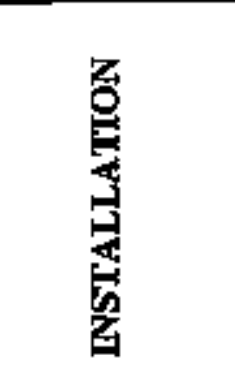 } & HENRAUSINCLUDED & COSTS INCLUD \\
\hline & $\begin{array}{l}\text { Energy } \\
\text { Savings } \\
\text { Only }\end{array}$ & $\begin{array}{l}\text { On-Site } \\
\text { Installation } \\
\text { Costs }\end{array}$ \\
\hline & \multicolumn{2}{|c|}{ Benefit/Cost Ratio $=1.61$} \\
\hline \multirow{3}{*}{ 悉 } & BRNAETS INCILUDRD & Costs INCLUDED \\
\hline & $\begin{array}{c}\text { Both } \\
\text { Energy and } \\
\text { Nonentergy Benefíts }\end{array}$ & $\begin{array}{l}\text { All } \\
\text { Cossts }\end{array}$ \\
\hline & \multicolumn{2}{|c|}{ Benefiticost Ratio $=1.72$} \\
\hline
\end{tabular}

National Benefit/Cost Ratios for All Fuel Types for the 1989 Program ators settled on an average cost of $\$ 500$ per single-family and small multifamily dwelling nationwide.

The evaluation examijed cost effectiveness in detail from three perspectives:

- The program perspective: the only benefit valued was net energy savings, and costs jacluded installation, management, and overhead costs.

- The installation perspective: the only benefit valued was net energy savings and the only costs included were installation expenditures; and

- The socletal perspective: bejefits ircluded both net energy and nonenergy bertefits, and costs included installation, management and overhead.

\section{National Cost Effectiveness}

The results of each of the three perspectives used to measure cost effectiveness are described below.

The program perspective is the most conservative analysis because it includes all classes of costs (i.e., both installation costs and program overhead and management) but only the value of energy savings as a benefit. From this perspective, the national program is still cost effective. For gas-heated homes, the benefit/cost ratio is 1.06 . For electrically heated homes, the ratio is 1.13, and for dwellings located in the Northeast heated pximarily with fuel oil, the benefit/cost ratio is 1.48 .

For the Program as a whole, including all fuel types, the program benefit/cost ratio is 1.09 .

The installation perspective is the traditional approach used to evaluate weatherization programs. Nationally, for gas-beated dwellings, weatherization costs averaged $\$ 1,015$ in 1989 dollars. Average energy 


\section{DOMESTIC HOT WATER}

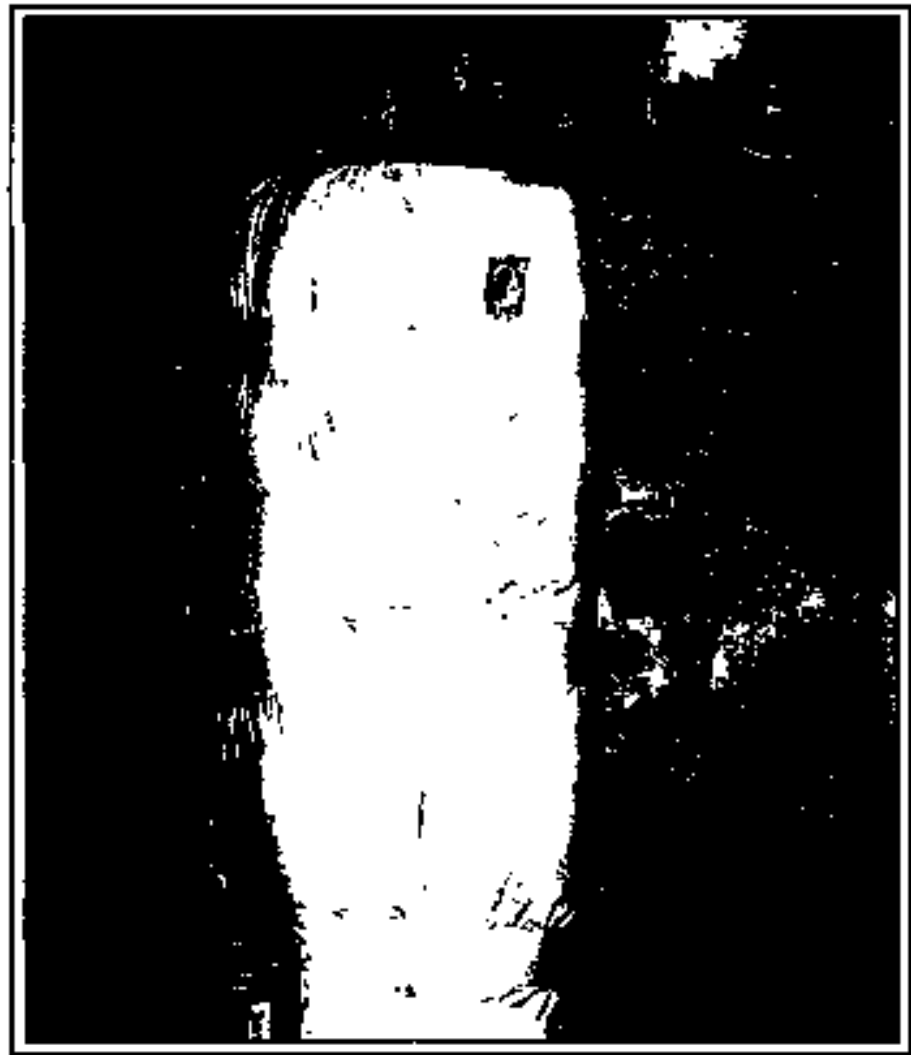

Conserving energy used to heat water is usually a cost-effective undertaking. Stopping leaks with minor plumbing repairs can result in substantial savings, as can installing low-flow devices like shower heads and faucet aerators. Most weatherization agencies report that the best results come from combining client education with goodquality shower heads. Similarily, the installation of tark insulation by weatherization agencies is frequently accompanied by turning down the thermostat on the water heater, an action that is often taken in conjunction with client education to promote sustained energy savings. Many agencies also install pipe insulation a few feet on the cold water inlet side (to prevent thermosiphoning during the standby cycle) and 10 feet or more on the hot water side.

Welr-insulated water heaters use less futel.

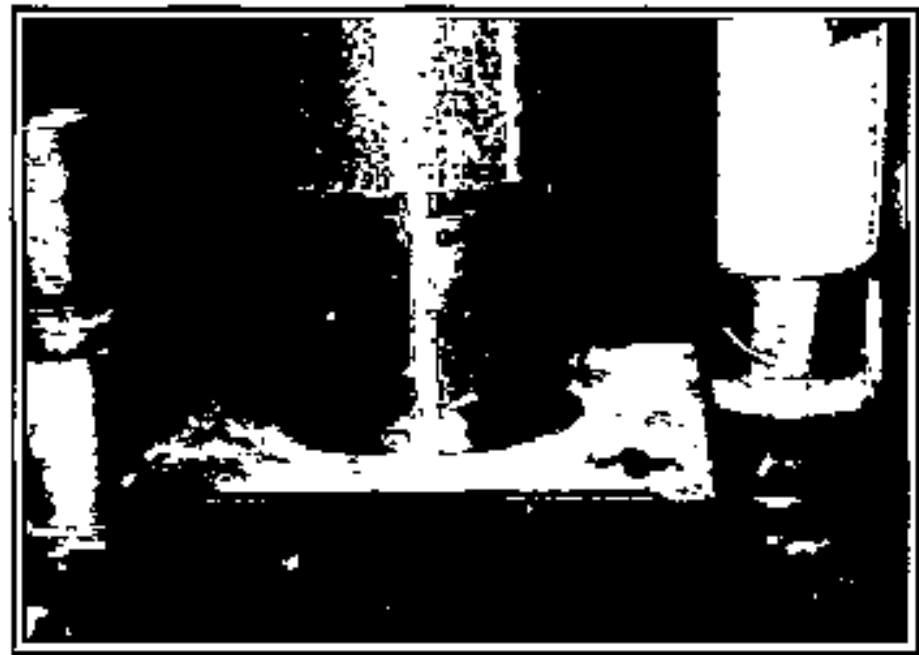

A flue damper installed on this domestre hot water heater limits heat loss to the chimney during the off cycle.

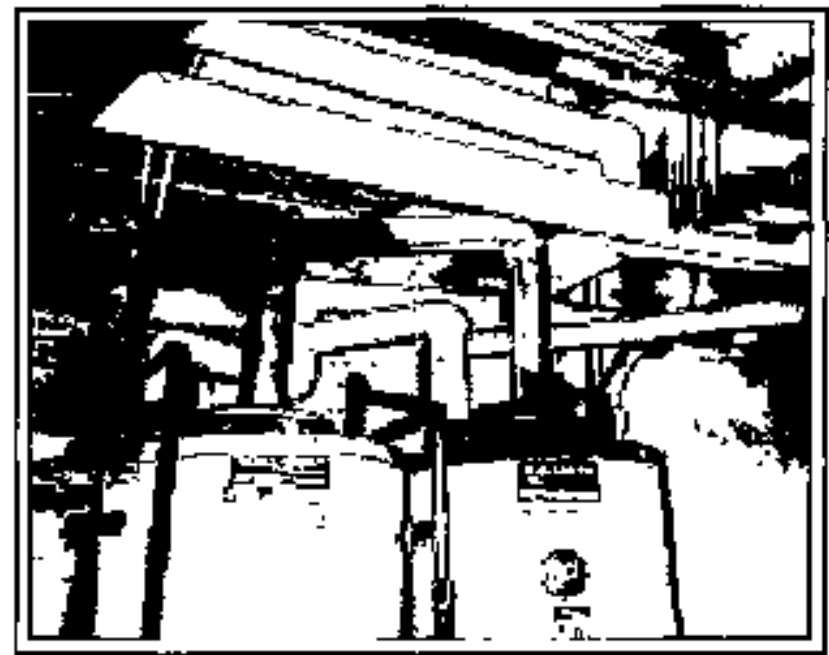

The weatherlzation crew that insulated the tank and pipesentering and exiting from this hot water heater did an excellent fob. 


\section{Benefit/Cost Ratios for Gas-Heated Homes}

\begin{tabular}{|l|c|c|}
\hline Perspective & 1989 & 1996 \\
\hline Progrant & 1.06 & 1.79 \\
\hline Installation & 1.58 & 2.39 \\
\hline Societal & 1.61 & 2.40 \\
\hline
\end{tabular}

savings benefits were calculated to be worth $\$ 1,605$. The resulting benefiv cost ratio, therefore, is 1.58 . For electrically heated dwellings, average expenditures of $\$ 1,025$ yield energy savings benefits of $\$ 1,728$, producing a benefit/cost ratio of 1.69 . For dwellings located in the Northeast heated primarily with fuel oil, average installation costs of $\$ 1,192$ yielded energy saving benefits of $\$ \mathbf{2 , 6 9 4}$, producing a benefit/cost ratio of 2.26 .

For the 1989 Program as a whole, including all fuel types, the installation benefit/cost ratio is 1.61 .

The societal perspective produces the highest benefit/cost tatios because it includes an estimated value of the nonenergy benefits of weatherization (\$976), which exceeds the overhead and management costs of weatherization ( $\$ 500)$. For gas-inated dwellings, the benefit/cost ratio is 1.61. For electrically heated dwellings, the benefit/cost ratio is 2.33. For fuel-oil-heated dwellings located in the Northeast, the benefit/cost ratio is 2.01 .

For the Program as a whole, including all fuel types, the societal benefit/cost ratio is 1.72 .

The bottom line is that the Program is a cost-effective government investment. Total costs (including materials, labor, overhead, and management) for all fuel types averaged $\$ 1,550$ per single-family and small multifamily dwelling weatherized in Prograrn Year 1989. The net current value of the energy saved per dwelling is $\$ 1,690$ (in 1989 dollars). This results in a benefit/cost ratio of 1.09 . When conservative values are included for some of the Program's various nonenergy benefits, the benefitloost ratio increases to 1.72 .

Because of the higher average national savings estimated for the Program in the 1996 Metaevaluation, cost-effectiveness estimates also increased. In 1989, the National Evaluation estimated the Program benefit' cost ratio for gas-heated homes from the program perspective as 1.06 . Applying the same procedures and assumptions used in the National Evaluation to the 1996 savings estimate yields a benefit/cost ratio of 1.79. With the installation perspective, the 1989 result is I.58, and for 1996 is 2.39. Societal ratios, which include the value of nonenergy benefits, were 1.61 in 1989 , and 2.40 in 1996.

\section{E. Performance by Climate Region in 1989}

Performance indicators for the national Program mask a great deal of diversity. This diversity spings from regional differences and associated housing types and needs and from varying practices of weatherization agencies. The following sections discuss differences by region. Characteristics of the houring stock and local agencies account for much of the regional vatiation in weatherization practices and measures installed. These, in turn, provide important background for understanding regional variations in weatherization costs, energy savings, and cost effectiveness.

As a whole, the 1989 Program was most cost effective in the cold and moderate climate regions of the country, where program activity was 


\section{MOBILE HOME MEASURES}

Many mobile homes have inconspicuous air leakage paths that car be clearly identified with blower doors. Successful weatherization work focuses on closing leaks at the bottom of the conditioned envelope, especially around the duct system. A recent Indiana study showed that 32 percent savings in mobile homes resuited from blower-door guided infiltration reduction and from blowing cellulose jnsulation in the belly board. A recent evaluation of the Vermont Weatherization Assistance Program ptovided evidence of substantial electricity savings from air sealing the water heater compartunent of mobile homes, even when the electric water heater had already been jacketed.

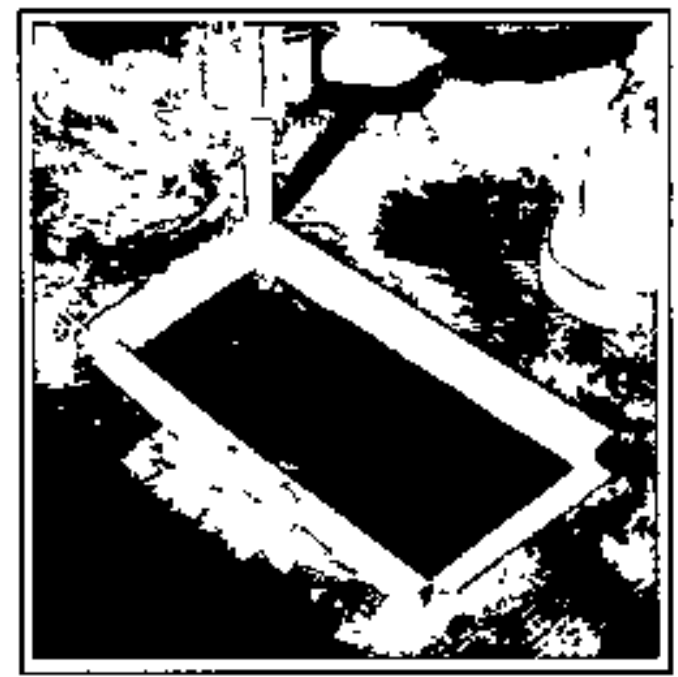

Theintmrfache between the riser in a supply duct and the loor of a mobile home is frequently found to be A souree of air leaks, both when the fumiace fan is on and when if is not. Here a technjcian in Intiana uses a technique hls agency developed to achitieve a tight, lifelong segl.

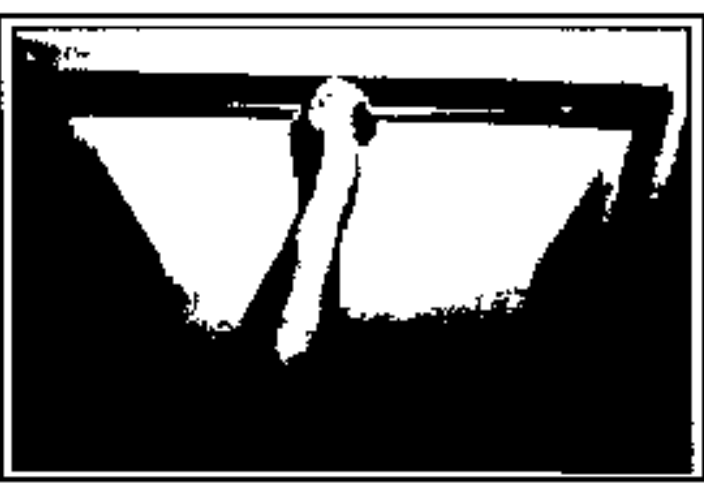

Sealing the opening to the evaporative cooler doring winter months is routinely accomplished by wentherization technicians in Artzona, who find this a very cost-effective weatherization tactic with both mobile hotues and site-bullt structures. Solar sereens also resnlt in significant savings in this semiviesert climate.

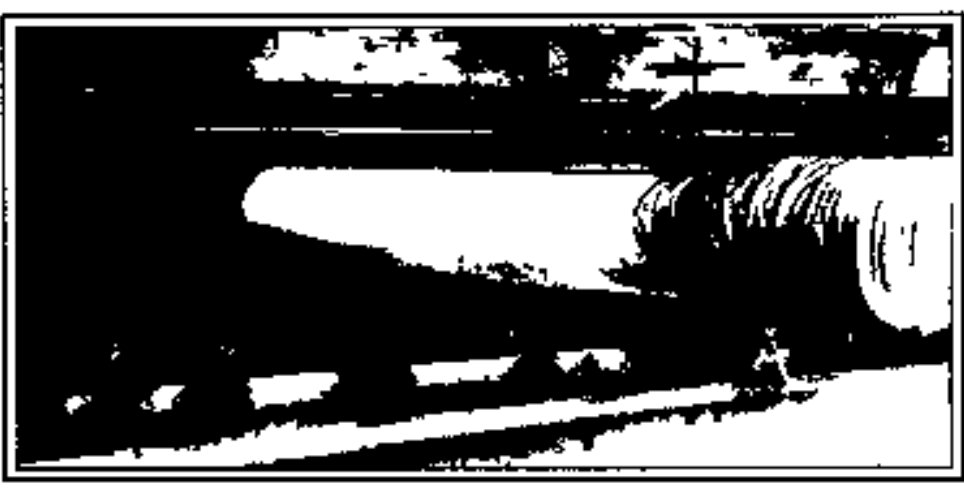

A 30-footulong plastic pipe is used to blow insalation between the belly board and the floor of a mobile home. 


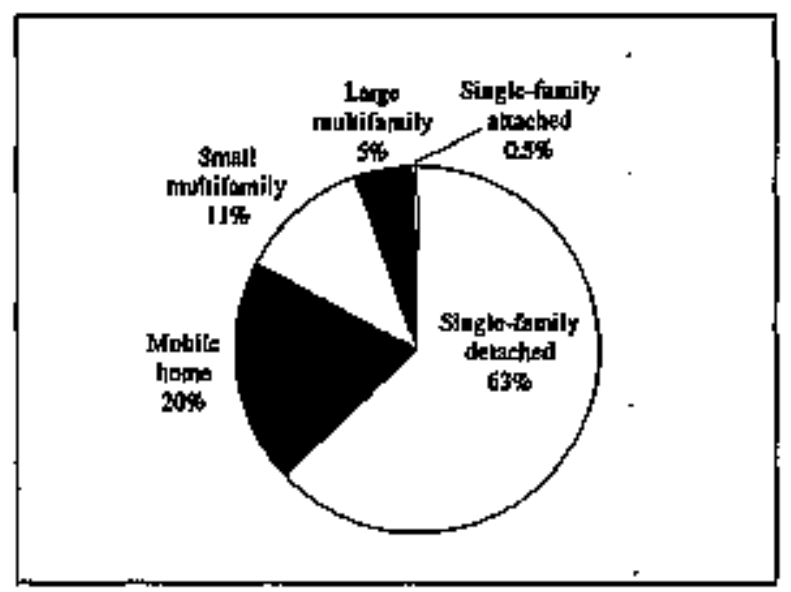

Types of Dwellings Weatherfzed in 1989 in the Cold Region concentrated. In the warm clinate region, where agencies were stmallest and the low-income housing was most dilapidated, the Program saved less energy per dollar expended.

\section{The Cold Climate Reglon}

The cold climate region contains 11 states with an average of 7,444 heating degree days. In 1989, approximately 150 local agencies in this region weatherized more than 40,000 dwellings (18 percent of the total weatherized population).

Benefit/cost ratios were greater in this region than in any other region, ranging from 1.3 to 2.9 depending upon the perspective. This region also achieved the highest savings of any region, based on the Single-Family Study. For natural gas consumption, the first-year net savings of 235 ccf represented a 25 percent reduction in the gas used for space heating and an 18 percent reduction in total gas usage. Net electricity savings totaled 2,686 $\mathrm{kWh}$ for the first year, which was a 42 percent reduction in electricity use for heating and a 14 percent reduction in total electricity usage. Total costs averaged $\$ 1,576$ per household, higher than the national average.

The majority of weatherized homes in the cold region are single-fanily detached (63 percent). Fiadings from the SingleFamily Study show that this region has the oldest bousing stock (averaging 45 years) and weatherizes dwellings that are on average larger than the other two regions (1,181 square feet). The primary beating fuel, as with all regions, is natural gas. This region, however, has a significantly higher portion of the population using fuel oil. A central heating system was found in 83 percent of the dwellings, the largest proportion of any region, and supplemental heating fueis were less common (24 percent of the weatherized single-family population). Two-thirds of these dwellings were owner-occupied, and they had the largest average number of occupants of any region.

The cold region used the most rigorous methods for both Types of Heating Fuels in Single Family and Snall Multifamily Dwellings Weatherized in 1989 in the Cold Region 
Funace testing for safety and efficiency has recently become a routine part of many weatherization operations, yer there are still states which pay Iittle attention to healing system work. Others do major work-when needed--ranging from switch-

From left to right: A botler technician, a local wegtherization official, and an owner celebrate the recent installation of an energy-effictent bofler in a large multifianily building in Brooklyn, Owners in New York and sonpe other states provide 25 percent or more of the cost of the work, thus leveraging scarce westherization fands.

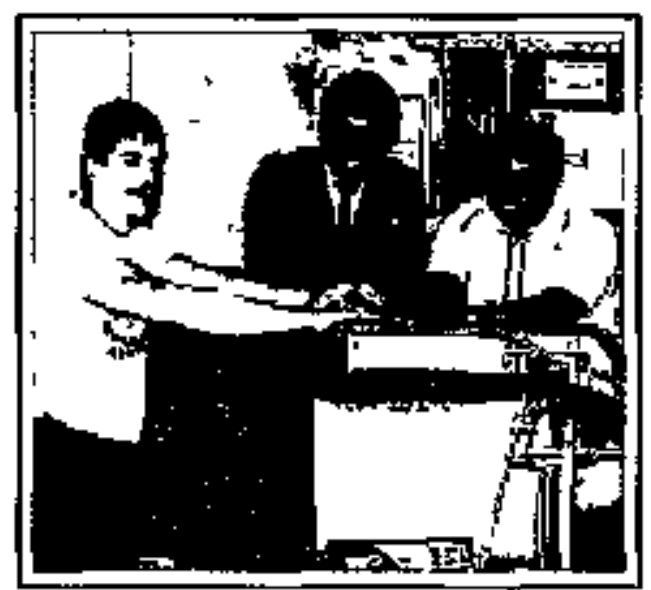
ing to efficient oil burners to boiler replacement.
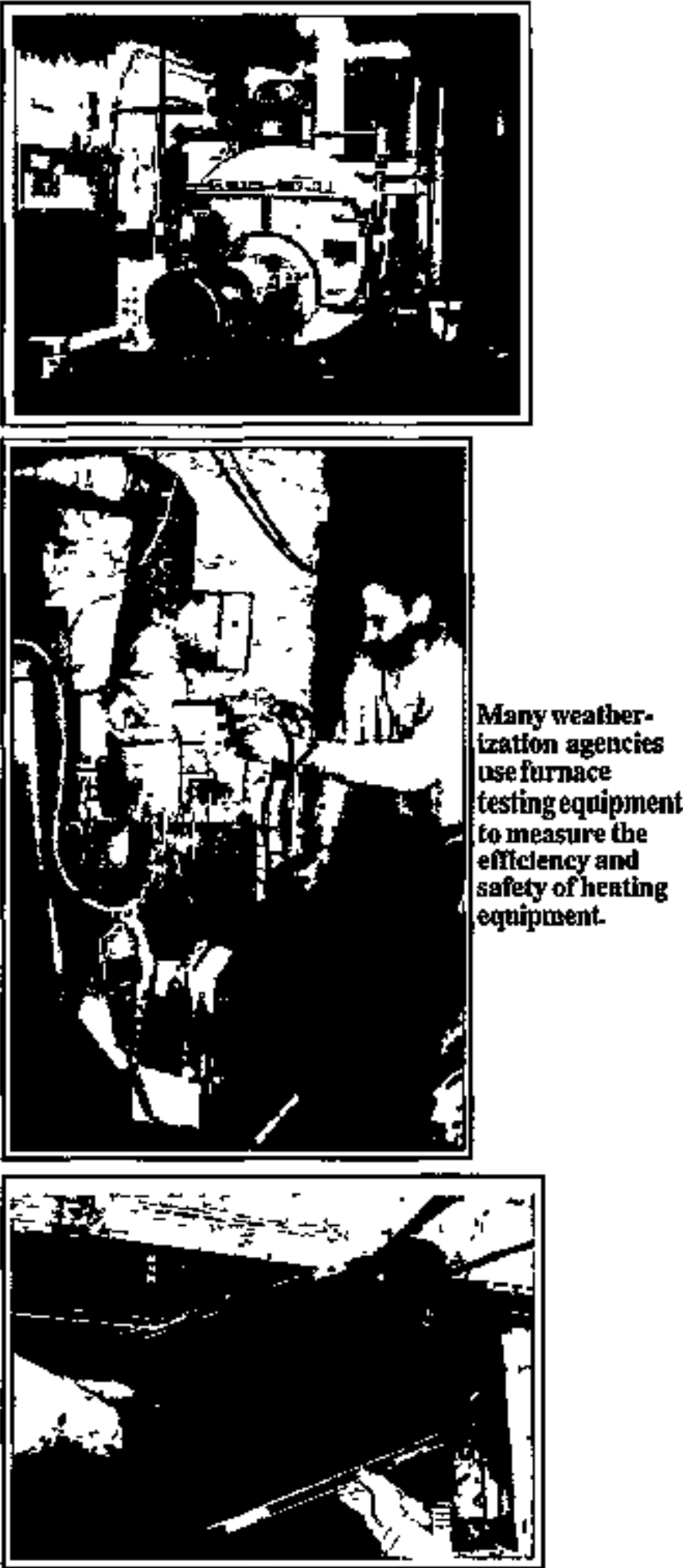

Filthy returnair filters, found frequently in the weather. ixation pros ram, are both tinhealthful and kneffictent. Cleanting and toning of furnaces, setting controks for efficency, replacing filters-and empowering clients to do the job in the future-are routinely accontplished in inost weatherizafion aperations. 


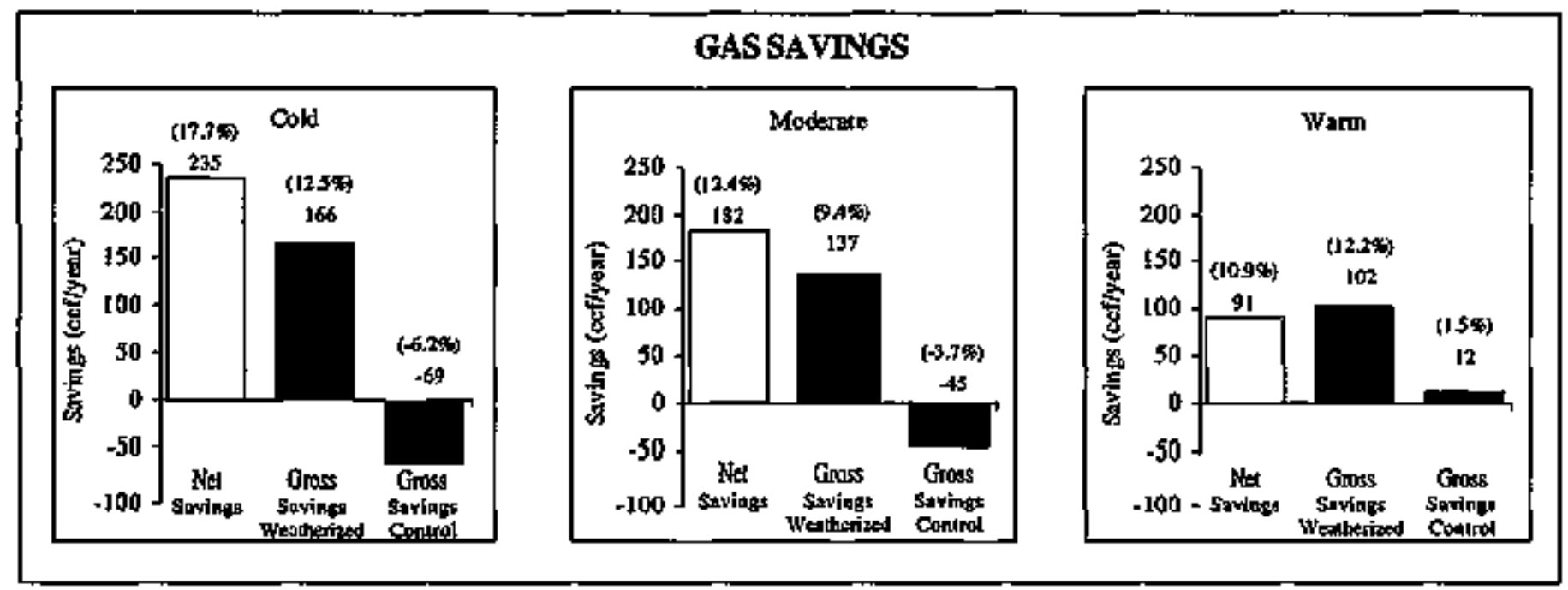

Gas Savings by Climate Region

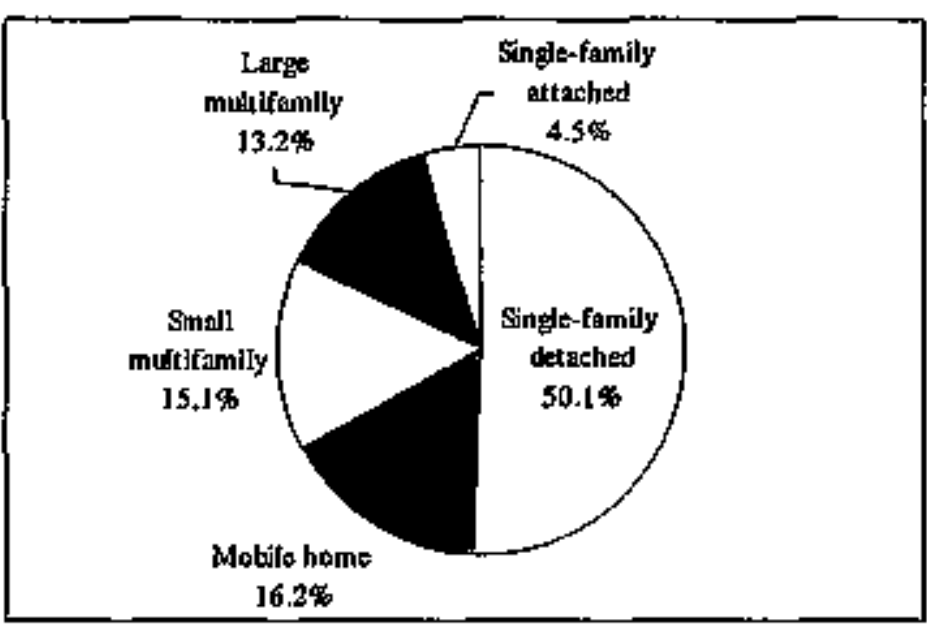

Types of Dwellings Weatherized in 1989 in the

Moderate Region

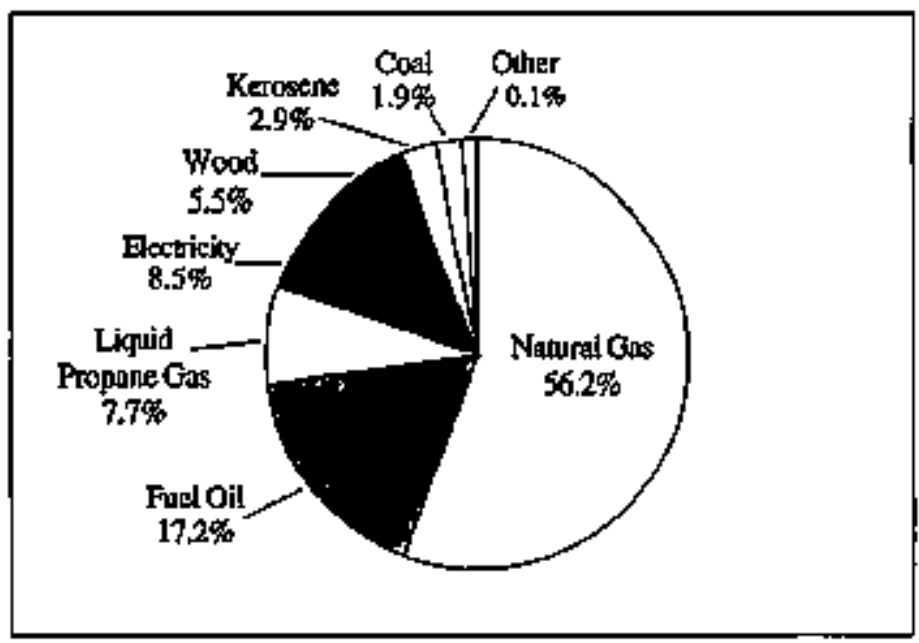

Types of Heating Fuels in Single-Family and Small Moltifamily Dwellings Weatherized in 1989 in the Moderate Region

\section{The Moderate Climate Region}

The moderate climate region consists of Washington, D.C., and 24 states, including the northern half of California. The region has an average of 5,906 heating degree-days. In 1989, this region contained nearly 570 local agencies that weatherized more than 140,000 dwellings ( 64 percent of the total weatherized population).

Benefit/cost ratios were substantial in the moderate region, ranging from 1.2 to 2.7 depending upon the perspective. This region also achieved higher than average savings, based on the SingleFanily Study. For natural gas consumption, the first-year net savings of 182 cef represented an 18 percent reduction in gas used for heating and a 12 percent reduction in total gas usage. Net electricity savings totaled $2,479 \mathrm{kWh}$ for the first year, which was a 44 percent reduction in electricity use for heating and a 15 percent reduction in total electricity use. Total costs ayeraged $\$ 1,580$ per household, essentialiy the same as the cold climate region investment level.

Just over half of the weatherized homes in the moderate region are single-family detached dwellings. This clinate zone also contains almost 88 percent of all large multifanily dwellings weatherized. Findings from the Single-Family Study show that this region has dwellings that are older than the nationsl average ( 44 years on average for the region). The use of natural gas is predominant in this region, with more than 56 percent of the weatherized dwellings (in the Single-Family Study) using this type of fuel. This region contains the smallest population of owner-occupied dwellings (59 percent of the single-family and small multifamily dwellings). 


\section{LARGE MULTIAAMILY MEASURES}

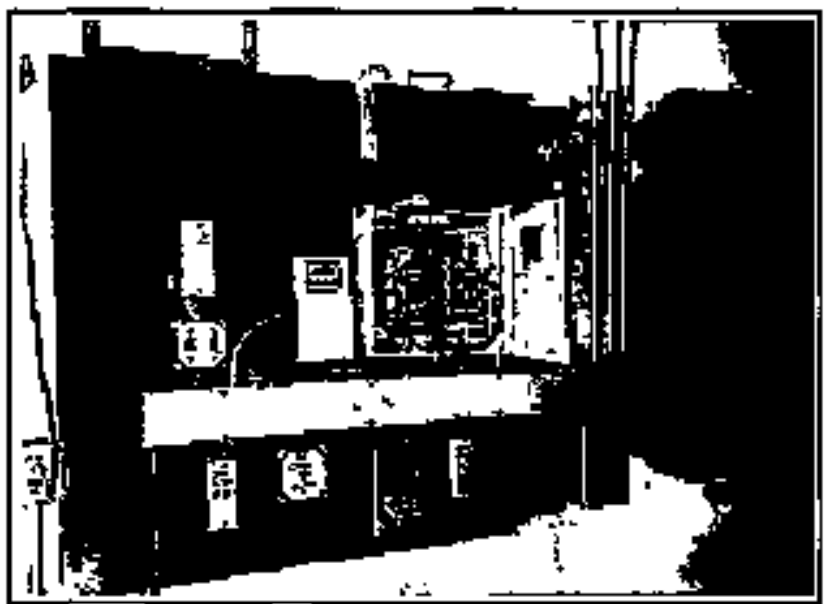

Electronic controls can contribute enormausly to savings. This device varies boiler firing time in response to outside air temperature and return condensate temperature to ensure esen heating

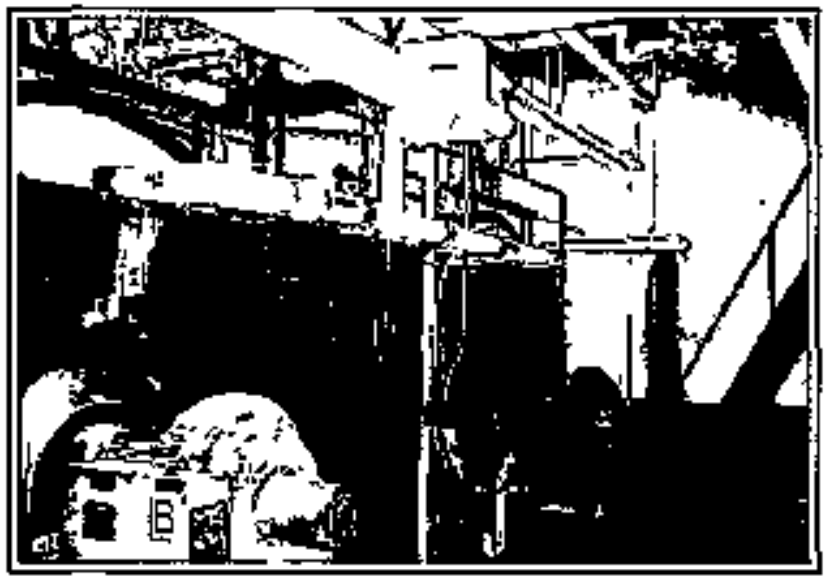

This large complex in the Bronx with 361 units now has a paif of new energy-efficient 200 horsepower boilers and a newly designed distribution controi system.

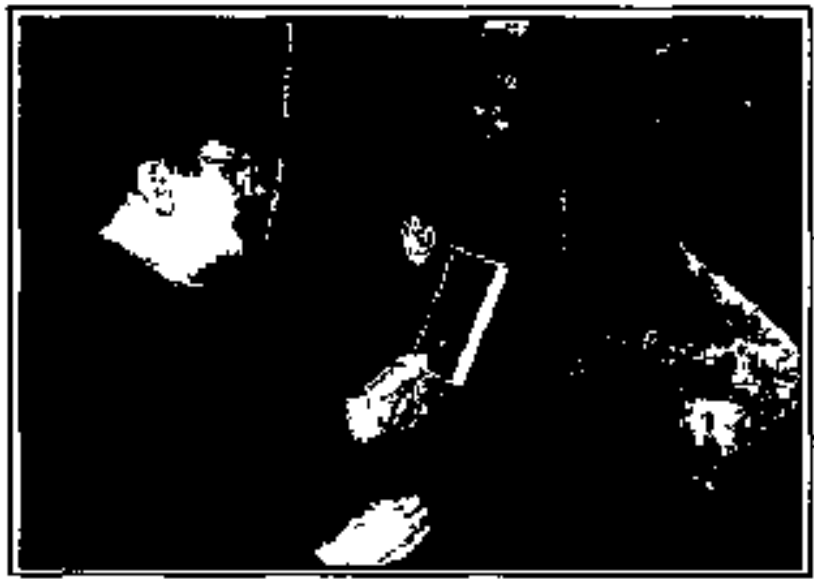

This manoneter is a preciston instrument that can he used as both a draft gauge (shiown with a large boiler) and as a tool to explore air leakiness between zones and stackeffectinfilltration.

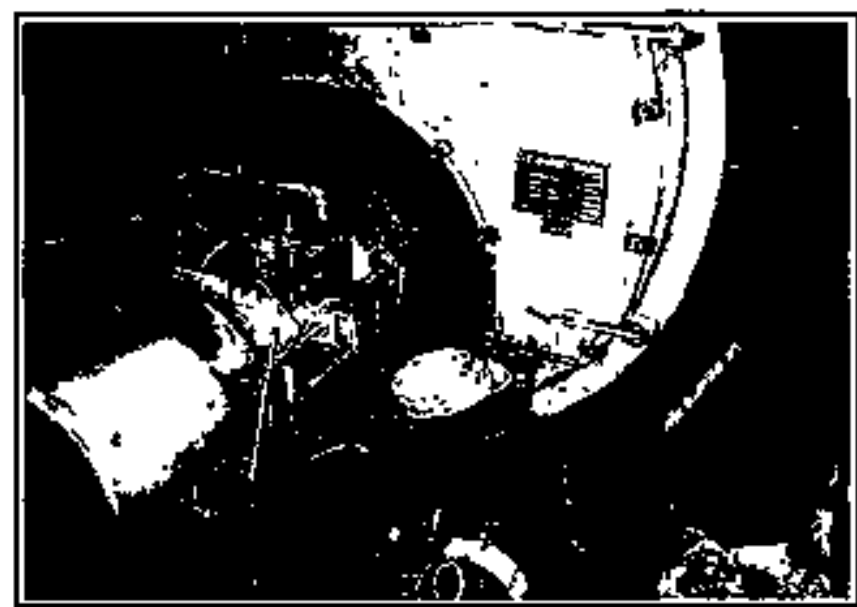

This complex in Brooklyn which was previously served by four, 40 horsepower gas-fired bollers is now served by a more efficient single 125 horsepower boiler fired with \#6 fued oll.

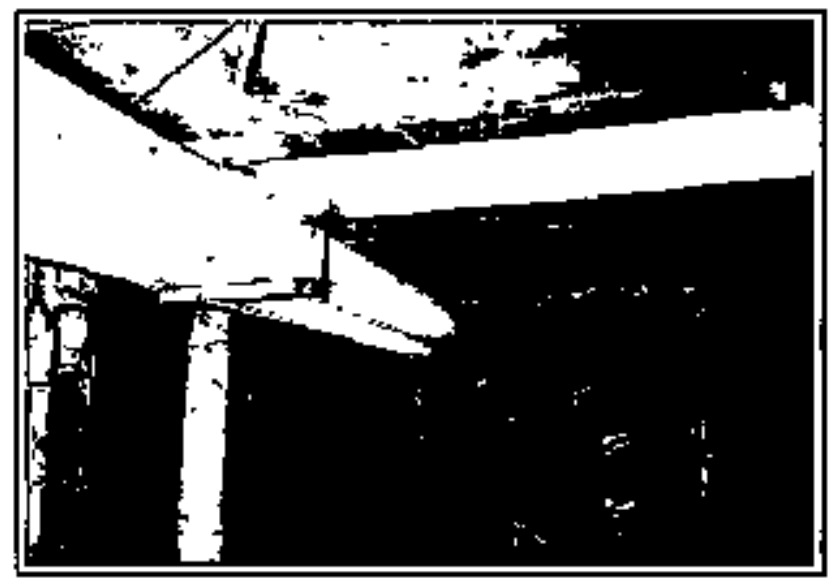

Newly insulated pipes traverse the boiler room on the way to aparbments upstalrs. Thesuperfutendent has added the alr sealing job and fresh paint.

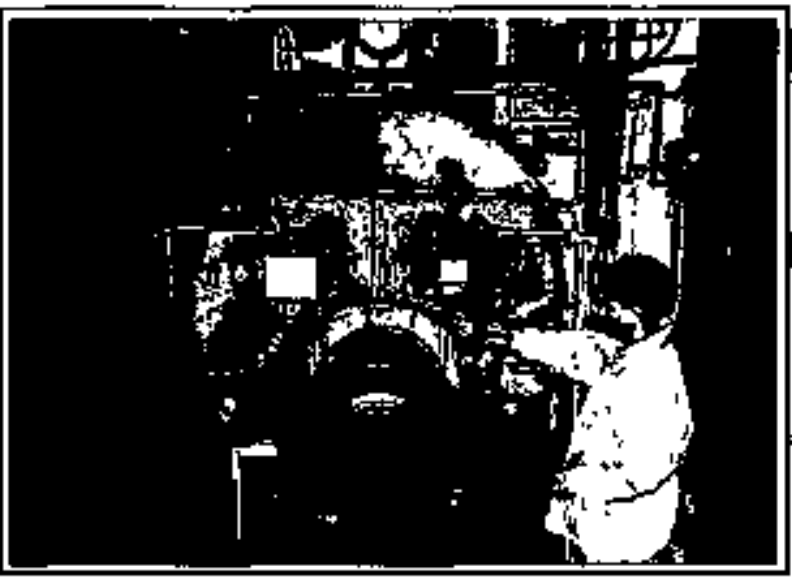

Old bolkers such as this one have substantial radiational heat losses, here being measured with a spot radiometer. 


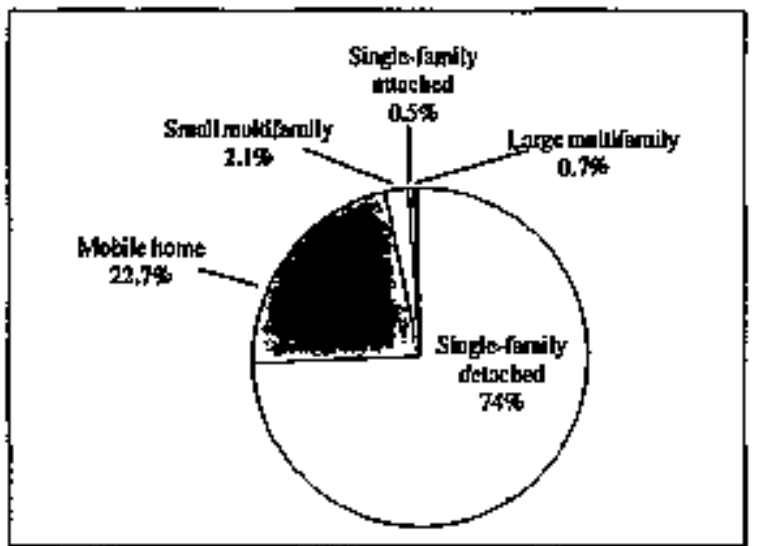

Typcs of Dwellings Wealhertzed ln 1989 in the Warm Region

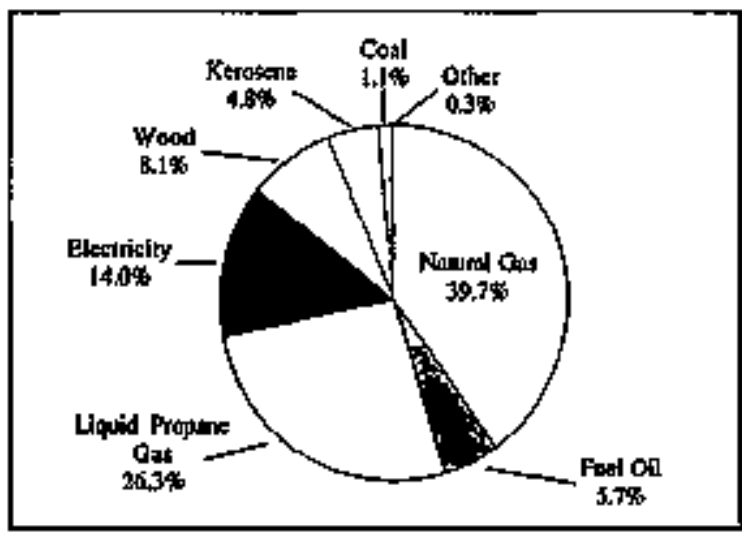

Types of Heatlng Fuels in Single-Famlly and Small MuttInmily Dwellings Weatherized in 1989 in the Warm Region
In the moderate region, only 15 percent of the clients were selected on the basis of estimated energy use or savings, as compared to 43 percent in the cold region. Sinilarly, integrated audits were used in only 5 percent of the dwellings, compared to 28 percent in the cold region. However, this region excelled in the use of beating efficiency tests as a diagnostic tool and later for quality control. In the moderate region, all of the major types of weatherization measures were installed at higher than national rates.

\section{The Warm Climate Region}

The warm climate region consists of 14 states, including the southem half of California, and has an average of 2.527 heating degree days. In 1989, this region contained nearly 380 local agencies, which served 40,000 dwellings (18 percent of the total weatherized population).

Benefit/cost ratios for the warm climate region in 1989 ranged from 0.4 to 1.6 depending on the perspective. This region saved less than the notional average, based on the Single-Family Sudy. For gas-heated homes, the first-year net savings of $91 \mathrm{ccf}$ represented a reduction of 15 percent of total gas used for heating and an 11 reduction in total gas usage. Net electricity savings totaled 595 $\mathrm{kWh}$ the first year, which was a 16 percent reduction in the electricity use for heating, or a 5 percent reduction in total electricity use. Total costs averaged $\$ 1,469$ per household, the lowest in the nation.

Nearly three-quarters of the weatherized homes in the warm climate region are single-family detached homes. This region also has the largest population of mobile homes (23 pencent of weatherized dwellings). Findings from the Single-Family Study show that this region has by far the youngest and smallest dwellings (averaging 33 years and 987 square feet, respectively). Liquid propane gas is used as a primary heating fuel approximately twice as often as the national weighted average, and central heating systems were present in only one-quarter of the homes weatherized in 1989. This region also bas the largest proportion of elderly oocupants (62 percent

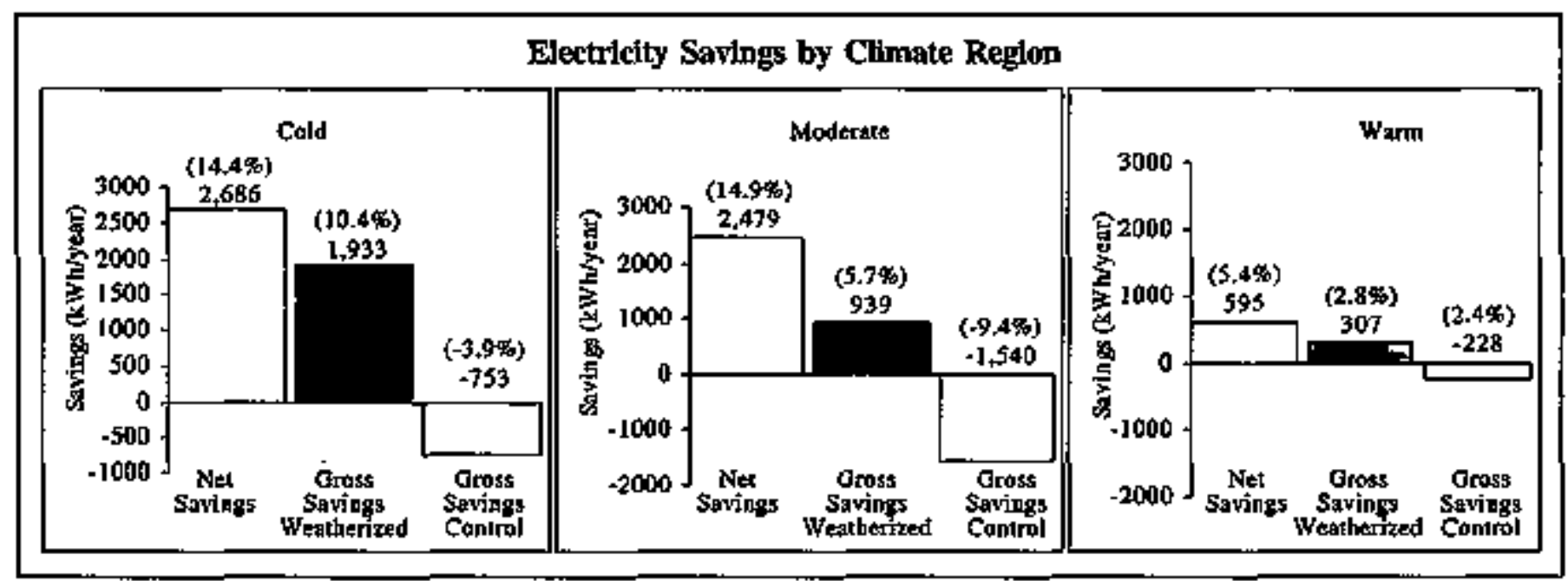




\section{TARGETING SAVINGS POTENTIAL}

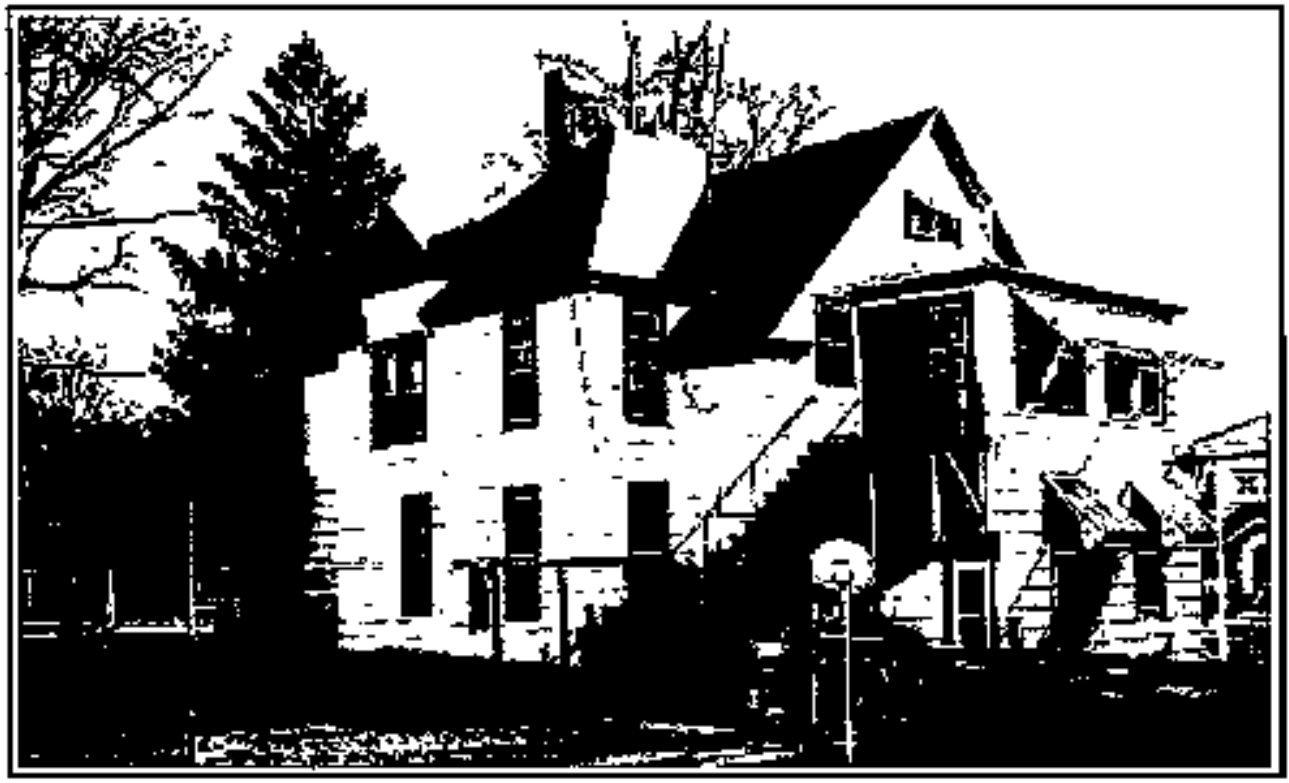

This 90-year-old home in Nebraska has more than 4,000 square feet of heated living space and 43 wirkdows for its 10 occupants (eight children and two parents). Althougt the home had 43 stom windows ptior to weatherization, the heating system was inefficient, the attic insulation was insufficient, and no floor or wall inșulation was present. Before weatherization, the house consumed 4,800 ccf of gas each year, resulting in annoal heating bills of approximately $\$ 2,500$, creating a signiftcant energy burden for this household.

The local weatherization agency spent $\$ 2,250$ in direct materials and labor from a variety of funding sources to weatherize this home. Most of its effort was dedicated to adding insulation to the attic, sidewals, kreewalls, collar beams, and floor. In addition, the water heater and water pipes were insulated; air leakages were sealed; the space heating system was cleaned, tuned, and repaired; and several doors and windows were fixed.

These weatherization measures resulted in a $25 \%$ reduction in the household's home heating bills, and created a much more comfortable living environment. The occupants described their home as "very drafty" prior to weatherization and "not at all drafty" afterwards.
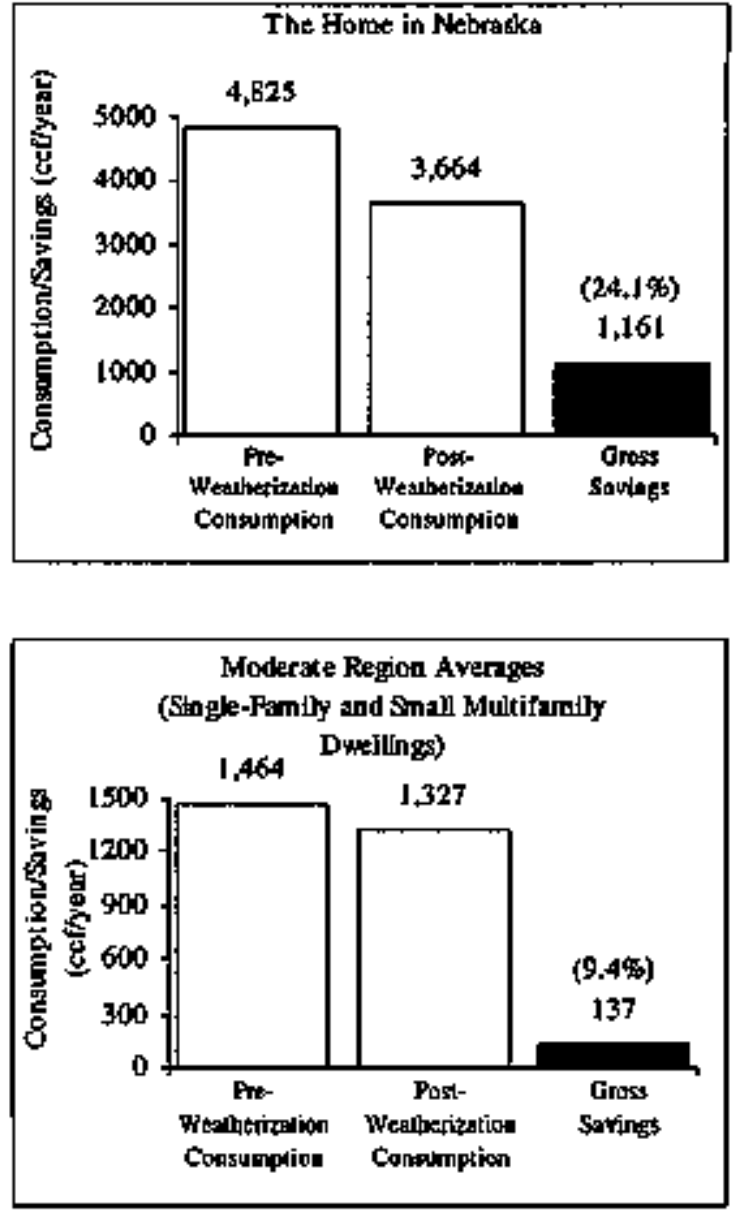
higher than the national average) and handicapped occupants (67 percent higher than the national average).

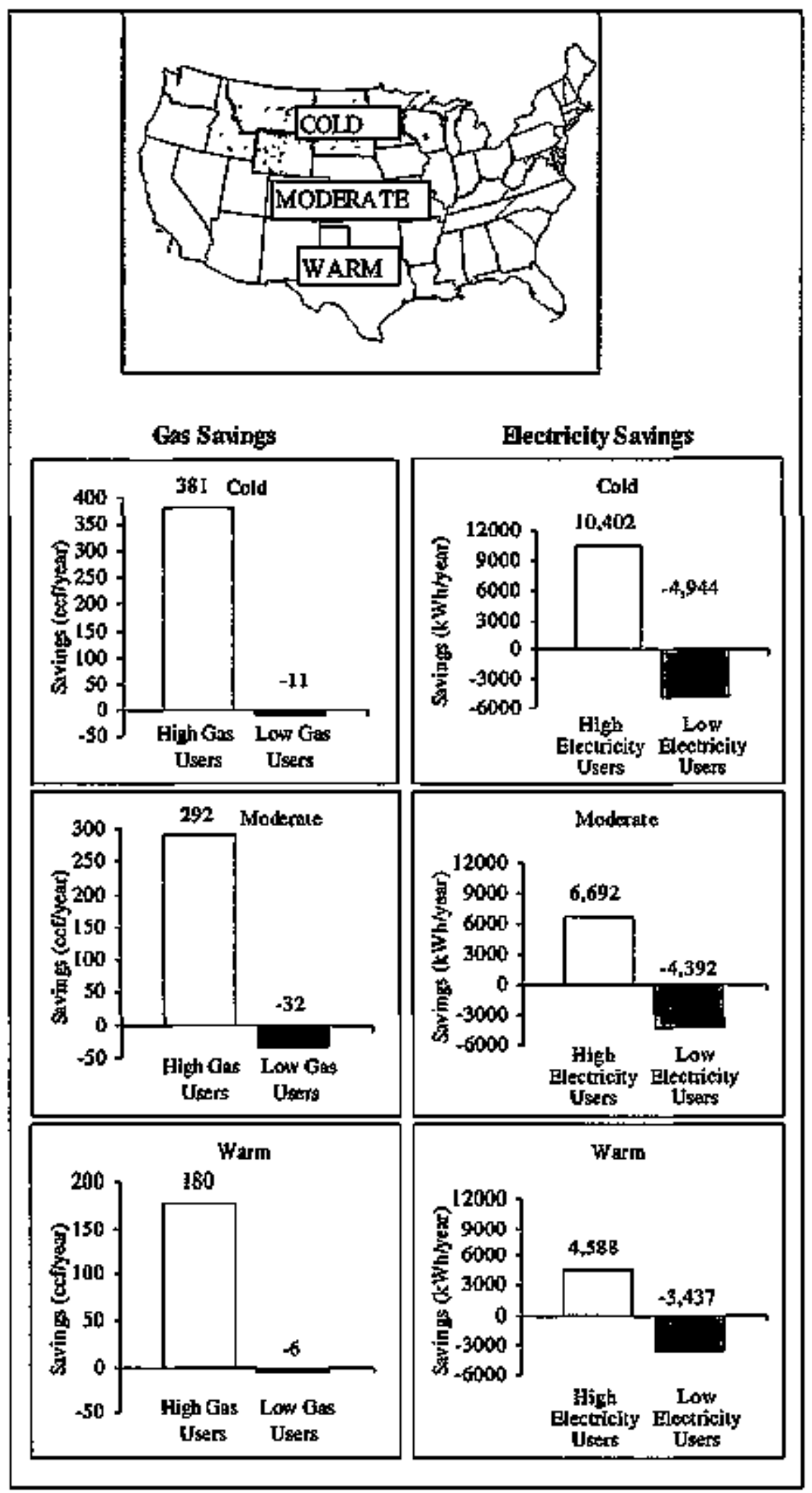

Energy Savngg Are Grealest tn Homes That Use the Mast Energ
In 1989, the measures used in this region were usually selected from priority lists rather than through the use of an energy audit, and sophisticated diagnostics were rarely used. Space-heating measures were installed in only 2 percent of the dwellings in this region, according to the Single-Family Study. Insulation and air leakage control measures were also installed less frequently than the national average. In contrast, the warm climate region installed more window and door measures and spent 28 percent more than the national average on structural mezsures, reflecting the more dilapidated condition of low-income housing in this region.

\section{RESPONSE TO EVALUATION FINDINGS}

The fundamental purposes of the National Weatherization Evaluation were to analyze Program performance to date and to identify promising opportunitjes for the future. Identifying the measures that produce substantial savings is critical in providing useful feedback to weatherization practitioners.

Since 1989, many of the opportunities for Program improvement identified by the National Evaluation have been implemented. The increased inplementation of these measures is a major source of the higher savings found in the 1,996 Metaevaluation.

\section{A. Savings Associated with Specific Program Practices}

The National Evaluation found that the following practices were associated with higher-than-average savings:

- Weatherizing high energy users. Within each climate region, weatherizing high energy users is associated with high energy savings. High energy use usually points to specific weaknesses in the dwelling's envelope or heating system. Solving 


\section{ADVANCED ENERGY AUDITS}

Advanced energy audits consider both envelope and heatiris and cooling system needs, and produce estimated energy savings, savings-toinvestment ratios, and a list of the quantities of materials necessary to complete weatherization. Anothes distinguishing feature of advanced tonergy audits is their use of billing histories to gauge the relative opportunities for savings and to reconcile engineering estimates of consumption and savings.

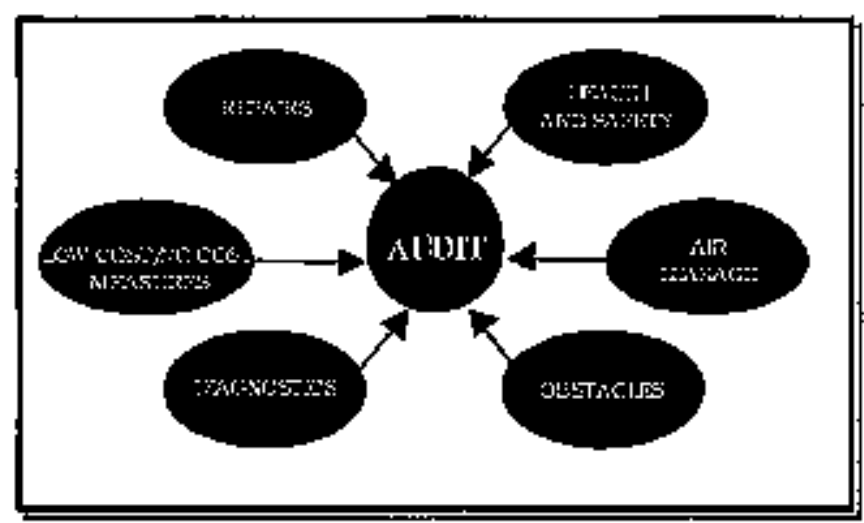

Adtuanced energy audits can tse a variely of data provided by the aucofitor and by diagnositic measurements (air leakage and equipment efífciencies).
The National Energy AudiT (NEAT) is a sophisticated computer-based audit developed specifrcally for DOE's Weatherization Assistance Program. NEAT uses a variety of data (on the building and its heating and cooling systems) to produce a prioritized list of cost-effective messures, custonized for an individual honse. It is advanced, yet user friendly.

This audit is one option for states. Some states have developed comparable audits tailored to their local needs.

\section{SIMPLIFIED OPERATION DIAGRAM OF NEAT}

At the "start"" users can:

1. enter building data,

2. customize setup of NEAT, and

3. recall previous building data.

At the "end," users have the option of entering and adjusting results with billing data.

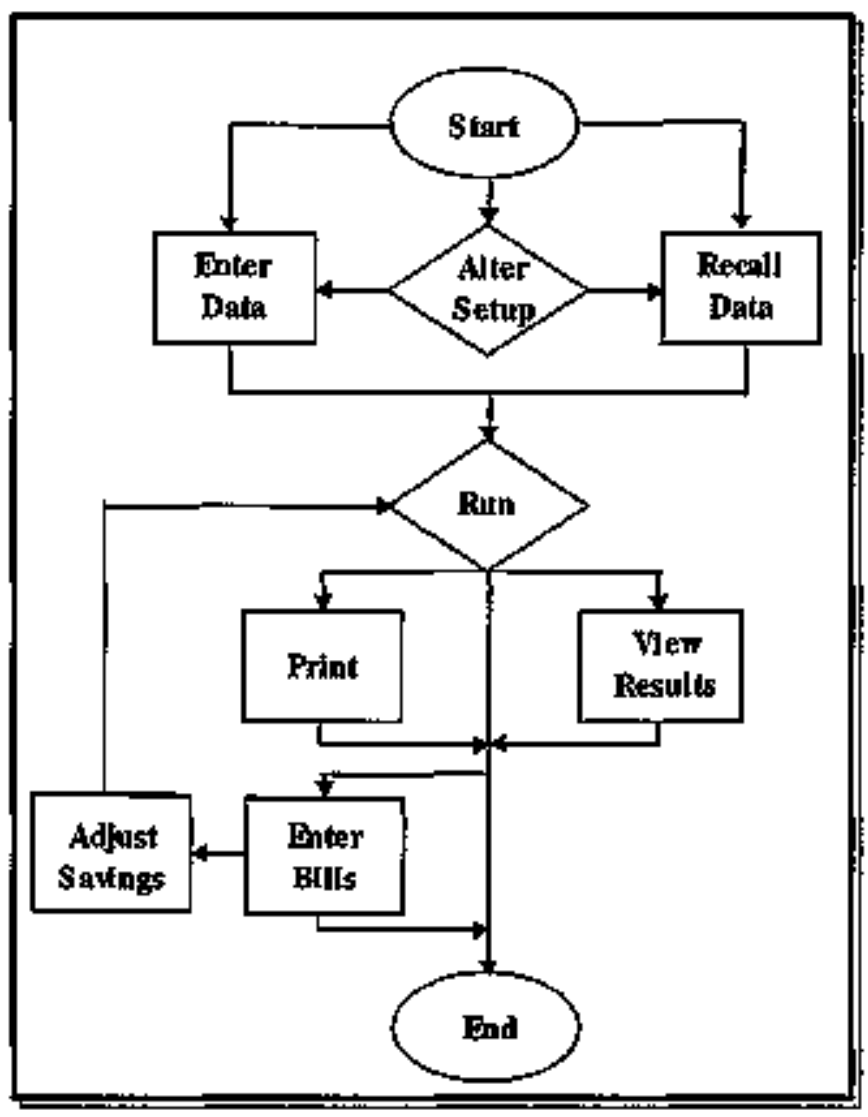




\begin{tabular}{|l|c|}
\hline \multicolumn{2}{|c|}{$\begin{array}{c}\text { Heating Energy Savings by Audic } \\
\text { Type in Experimental Study it } \\
\text { North Caroltina }\end{array}$} \\
\hline $\begin{array}{l}\text { Project } \\
\text { Retro-Tech }\end{array}$ & $23 \%$ \\
\hline $\begin{array}{l}\text { Advanced } \\
\text { Audit }\end{array}$ & $33 \%$ \\
\hline
\end{tabular}

such problems typically produces highly cost-effective savings. This is illustrated by the figure which shows dramatic differences between savings achieved by the weatherization jobs accomplished on the highest quartile of gas and electricity users and savings achieved on the lowest quartile.

The Metaevaluation also identified pre-weadnerization consumption as the best predictor of savings in regression models of state-level energy savings. Advanced audits, such as the New York Targeted Investment Protocol (TIPS) audit, direct higher investments to dwellings with higher usage (on a Btu/square footheating degree day basis). Dwellings with higher usage are typically more energy tnefficient, and, therefore, have greater room for improvement and higher potential for energy savings.

- Using an advanced audit. Advanced audits help pinpoint problems and guide weatherization work towards what makes a difference-and away from what doesn't. They consider both envelope and heating and cooling system needs, and provide savings-to-investment ratios for individual measures as applied to individual dwellings. Although advanced audits were just emerging in 1989, several of the highperforming agencies identified in the Single-Family Sudy used them.

By 1996, 37 states were using advanced andits. There is a good deal of evidence that advanced audits produce higher savings. For example, an experimental study in North Carolina, which took place in 1989-1991, compared the heating energy savings achieved with an advanced audit to those produced with Project Retro-Tech based procedures (which were standard in North Carolina at that time). This experiment compared three groups of dwellings: a group weatherized with the advanced audit, a group weatherized with Retro-Tech procedures, and a control group (Sharp, 1994). The staff of three local agencies, which performed all of the weatherizations, received a few days of training in the advanced audit procedures as a part of the study. Net heating energy savings for the advanced audit group were $33 \%$, for the Retro-Tech group $23 \%$, while the control group increased its consumption by $5 \%$. Average weatherization costs for the advanced audit group and the Project RetroTech group were the same (\$1,056 and $\$ 1,059$, respectively).

- Curing distribution system problems. Air leakage from distribution systems can cause serious health and safety problems, as well as affect energy consumption. Curing distribution system leakage is correlated with higher-than-nomal savings. Much more attention is given to distribution systems today than was the case in 1989.

- Replacing furnaces. This measure is not only positively correlated with higher-than-average savings, but also frecuently solves safety and health problems. Since this is usually a high-cost measure, its cost effectiveness--considered as only an energy conservation measure-is not always high. On the other hand, it often is a vital health and safety measure, since removing a fumace with a broken heat exchanger can improve indoor air quality and save lives. 


\section{BLOWER DOORS}

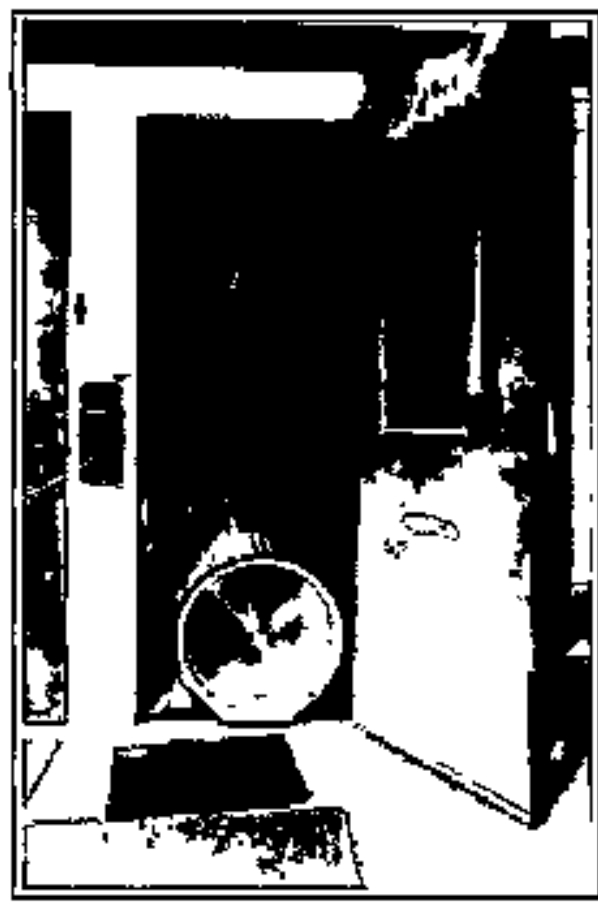

Blower door setup, outside view.

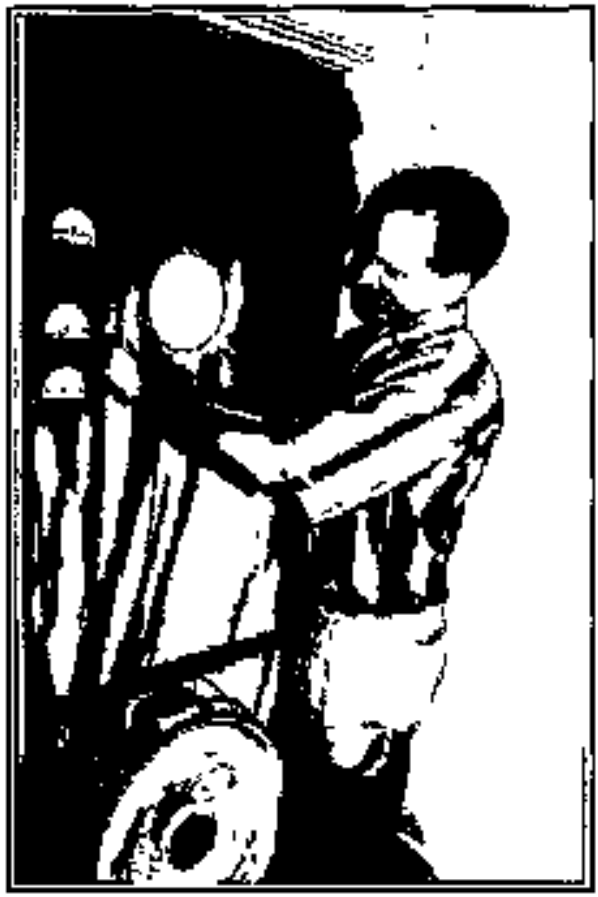

Blower door setup, inside view. The technician is zeroing the zalages, so as to measure both air fow and the inside-ontside pressure difference caused by the blower door. The speed of the fan is adjusted using the control on top of the tan.
Blower doors are variable-speed fans equipped with a frame and shroud that permits them to fit inside a variety of door frames. Instrumentation includes pressure gauges that enable the operator to detemine the flow of air through the fan as well as the pressure the fan induces on a dwelling. Since leakier trouses require more air flow to induce a given pressure difference, blower doors can measure the relative leakiness of a house. When used as a diagnostic instrument, they can also reveal the location of many leaks, thus providing a clear target for air sealing.

When the job is partially or fully complete, blower doors also provide technicians with fast feedback on the effectiveness of their work, thus contributing to increased practical wisdom on the part of the techricians and to the overali professionalization and efficiency of the weatherization process itself.

Experience has shown that high pre-weatherization blower door readings of flow (at a standard pressure of 50 pastals, for example) are strongly correlated with success in air sealing, as revealed by substantially lower postweatherization blower door readings.

Significantly, blower doors are also useful in revealing what does not need to be done, allowing weatherization crews to concentrate on real problems. This observation illuminates critical features of the evolution of the weatherization program and building science.

Prior to the advent of blower door technology and the detailed analysis of pattems of convective energy losses, conventional wisdom held that most air leakage occurs toward the mid-height of the conditioned envelope, primarily through doors and windows. Aceordingly, application of weatherstripping and caulking in those areas was advocated in DOE instructions and related publications and was widely practiced by weatherization technicjens and others. In the early days of blower-door-ajded diagnostics and air sealing-which for most weatherization agencies included the period of this evaluationthese practices continued. In fact, blower doors do reveal leaks from doors and windows, although their effects are amplified, since small areas result in high-velocity air currents. Gradually, however, it was discovered that leakage from doors and windows represents a relatively small percentage of convective losses in most dwellings, and that genuinely serious leaks tended to occur at the bottom and (especially) the top of the conditioned envelope. Accordingly, careful air sealing in attics and basements is increasingly practiced by weatherization crews in most areas of the country. The use of blower door technology should be periodically evaluated at the local Jevel to ensure that the technology promotes cost effectiveness in various circumstances. 
- Installing attic insulation. The 1989 evaluation clearly showed that the instaltation of insulation in attics never before insulated is particularly cost effective. Today adyanced andits consistently recommend more attic insulation than was recommended by the priority list selection procedures used by most agencies in 1989.

- Installing wall insulation. During the time of the 1989 evaluation, only a few agencies had begun using the high-density installation technique (which accomplishes air seating and insulation with a single operation). However, weatherizarion jobs that included high-density wall insulation showed even greater savings than those that used the older technique. More agencies are using high-density wall insulation techniques today.

- Blower-door-assisted air sealing. The payoff expected from blower-door-assisted air sealing was not discernible in the Single-Family Study in 1989. Because the effectiveness of blower-door-assisted air sealing has been demonstrated in small scale studies, this unexpected finding was attributed to the fact that blower doors were just being introduced into local agency procedures in 1989 , when only 18 percent of completed dwellings received blower-door-assisted sealing. Today, many agencies offer training in blower door use, and many homes receive blower-door-assisted sealing. In fact, low-income weatherization agencies have become leaders in the application of blower doors and are generally convinced they save energy.

\section{Recommended Practices}

- Client education

- Resource leveraging

- Utłlity partnerships

- Housing rehabilitation funds

\section{B. Promising Management Practices}

A handful of other practices employed by many weatherization agencies clearly make sense, but their impact coutd not be quantified in the 1989 evaluation. These include client education and resource leveraging. Some agencies are very active in providing client education and report good success in forming partnerships in which recipients of weatherization services participate in a number of concrete conservation activities in their homes.

Leveraging from utilities to accomplish the ends of demand-side management on the one hand and cost-saving conservation services for low-income families on the other has been an important opportunity for enhancing weatherization. Some agencies, for instance, provide electricity conservation services in conjunction with weatherization. These routinely involve removing inefficient incandescent lighting fixtures and replacing them with compact fluorescent lighting, and sometimes replacing inefficient refiigerators with efficient ones. Other utility partnerships have enabled capital-intensive investments such as energy-efficient replacenent fumaces that otherwise might not be possible.

Still problematic for many local agencies is the extremely poor condition of many dwellings. The Program will be stronger when 


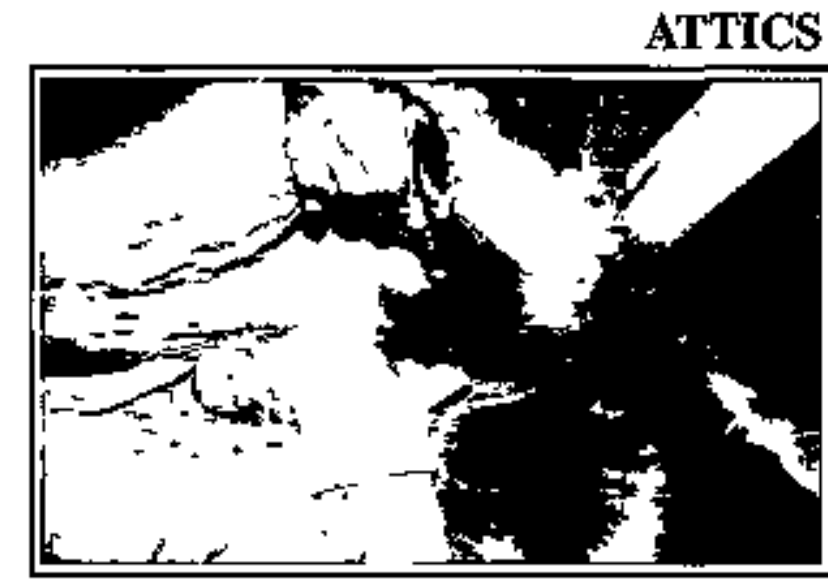

This is a 12-inch fiverglass hatt that has been on top of a small crack in the ceilling below for only one winter. The dirt is from the passing of massive aubounts of air driven by stack-effect exfiltration.

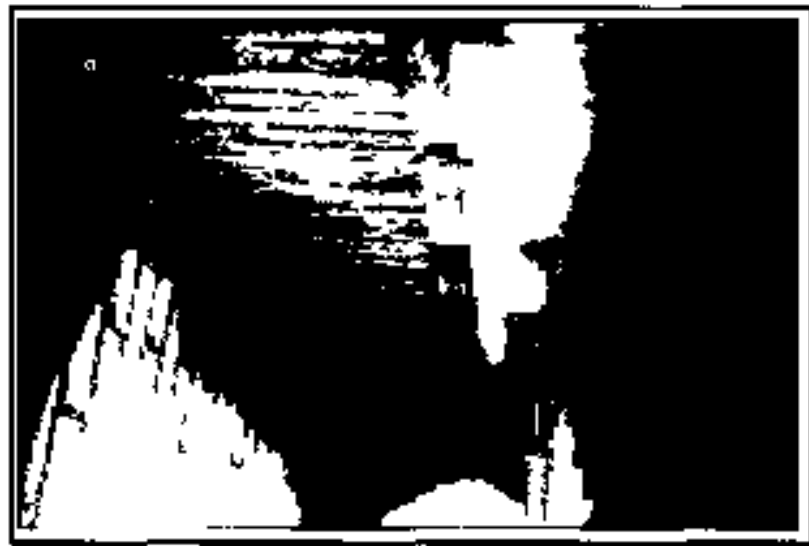

This space between the chimney interior framing is cortupletely open to the attic. Sealing this at thelevel of the attic insulation is likely to save more energy than replacing every window in the dwelling. An experienced weatherization crew technicinn can thoroughly (and safely) seal this opening in $15 \mathrm{~min}$ utes with a materlal cost of $\$ 4$.
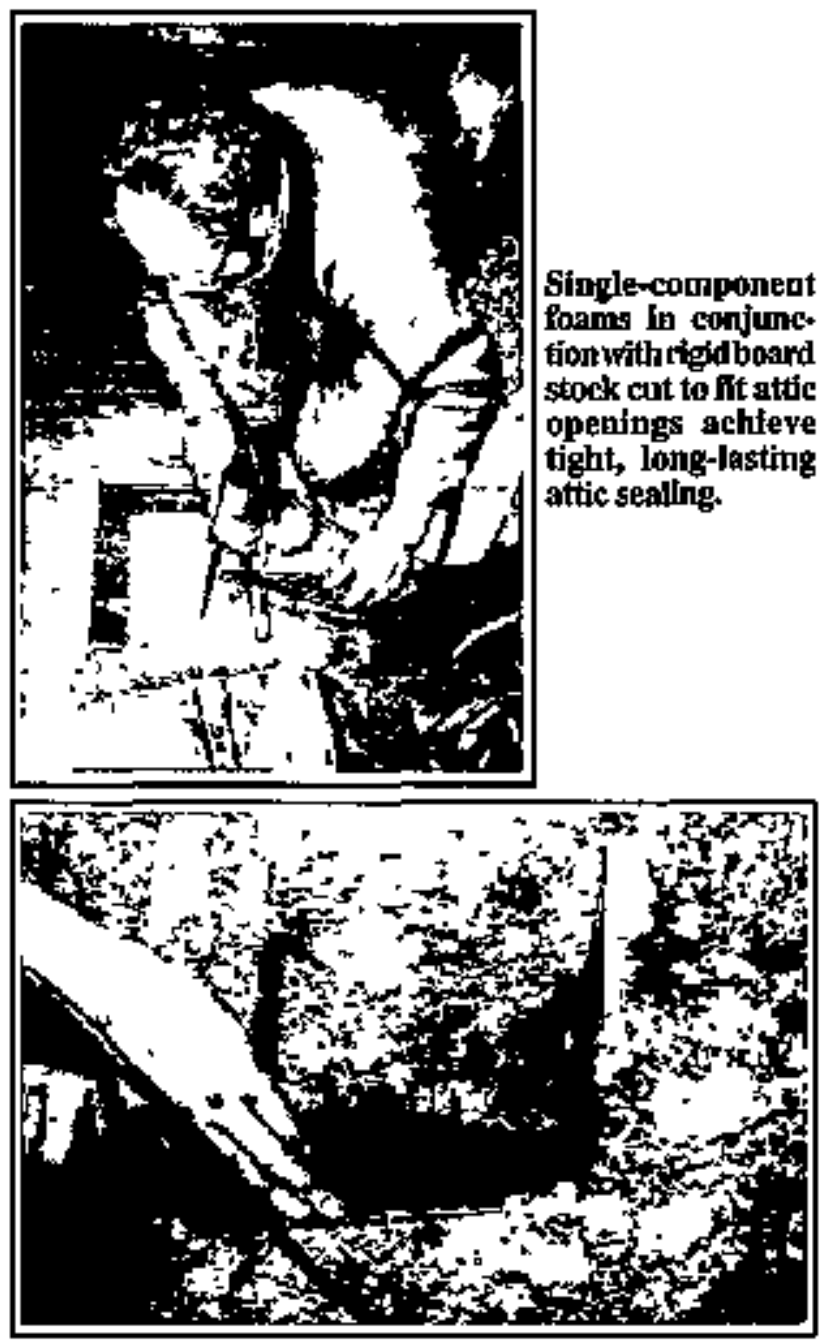

Interlor walls open toattics are commonplace-and must be sealed to prevent thermal siphoning. If this hole is notsealed during weatherization, the futerior wall below is Hkely to be much colker in the winter thas exterior insulated wals. 
adequate housing rehabilitation funding allows local agencies to provide needed repairs and to devote a larger share of their DOE funds to energyefficiency improvements.

\section{The Warm Climate Weatherization Initiative}

The lower-than-average savings in the warm climate region suggested the need for efforts designed to identify and implement ways of increasing energy savings from weatherization in warm climates. In addition, studies had decisively shown that improved procedures in warm climates could produce dramatic improvements in savings. The results of a 1993 ORNL study, for example, showed that the use of an advanced audit procedure more than doubled the amount of energy savings in North Carolina homes. A similar study in Virginia found that savings more than doubled with the implementation of improved procedures.

Although some improvements were already being adopted, DOE believed that it was important to accelerate the pace of change. Therefort, DOE decided to sponsor the Warm Climate Weatherization Initiative. This Initiative was designed to identify, develop, test, and transfer into widespread use a set of technological and programmatic approaches that can further increase the energy saved by weatherizing low-income homes in warm climates.

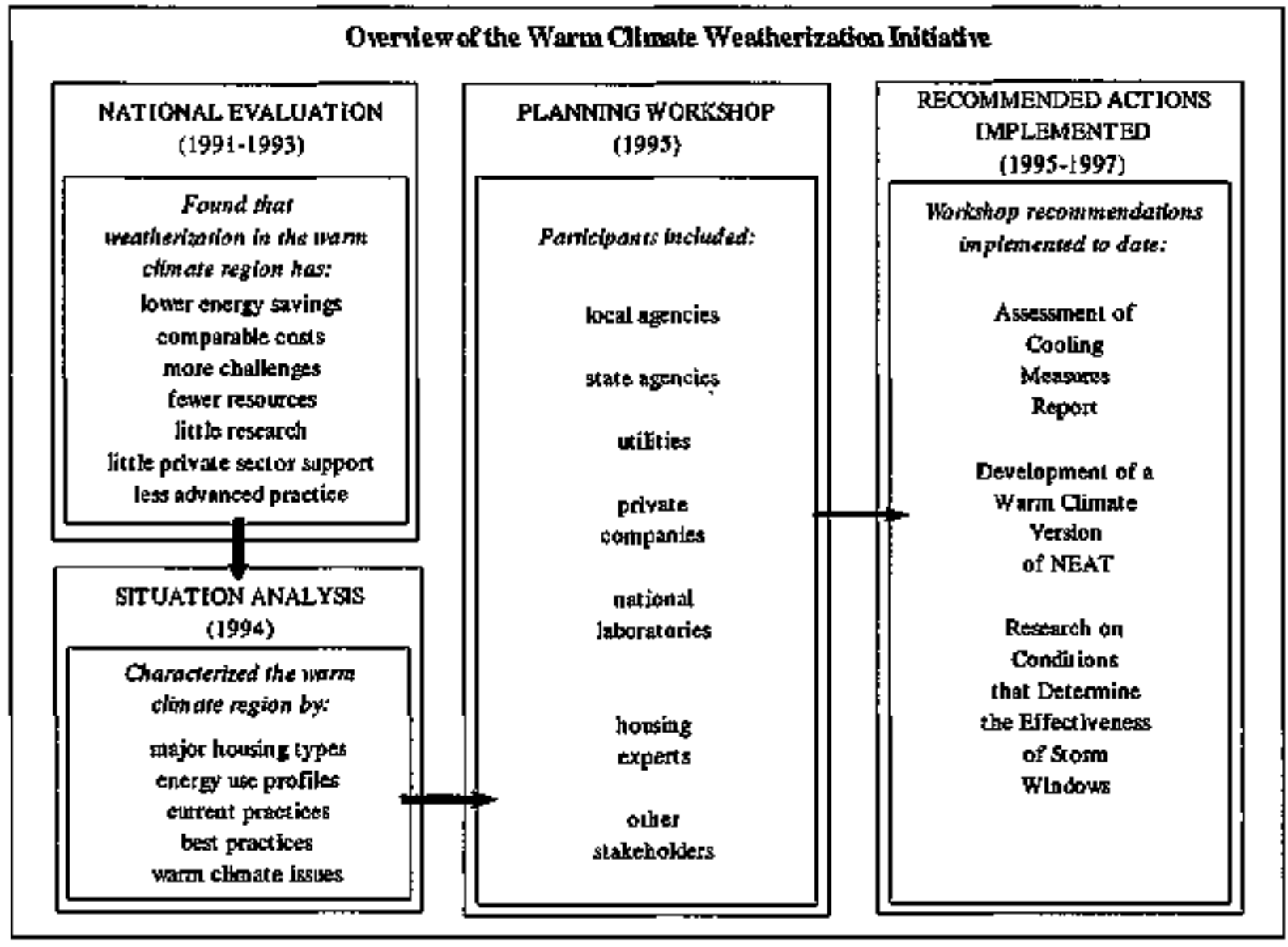




\section{RELATIONSHIP OF COSTS TO SAVINGS}

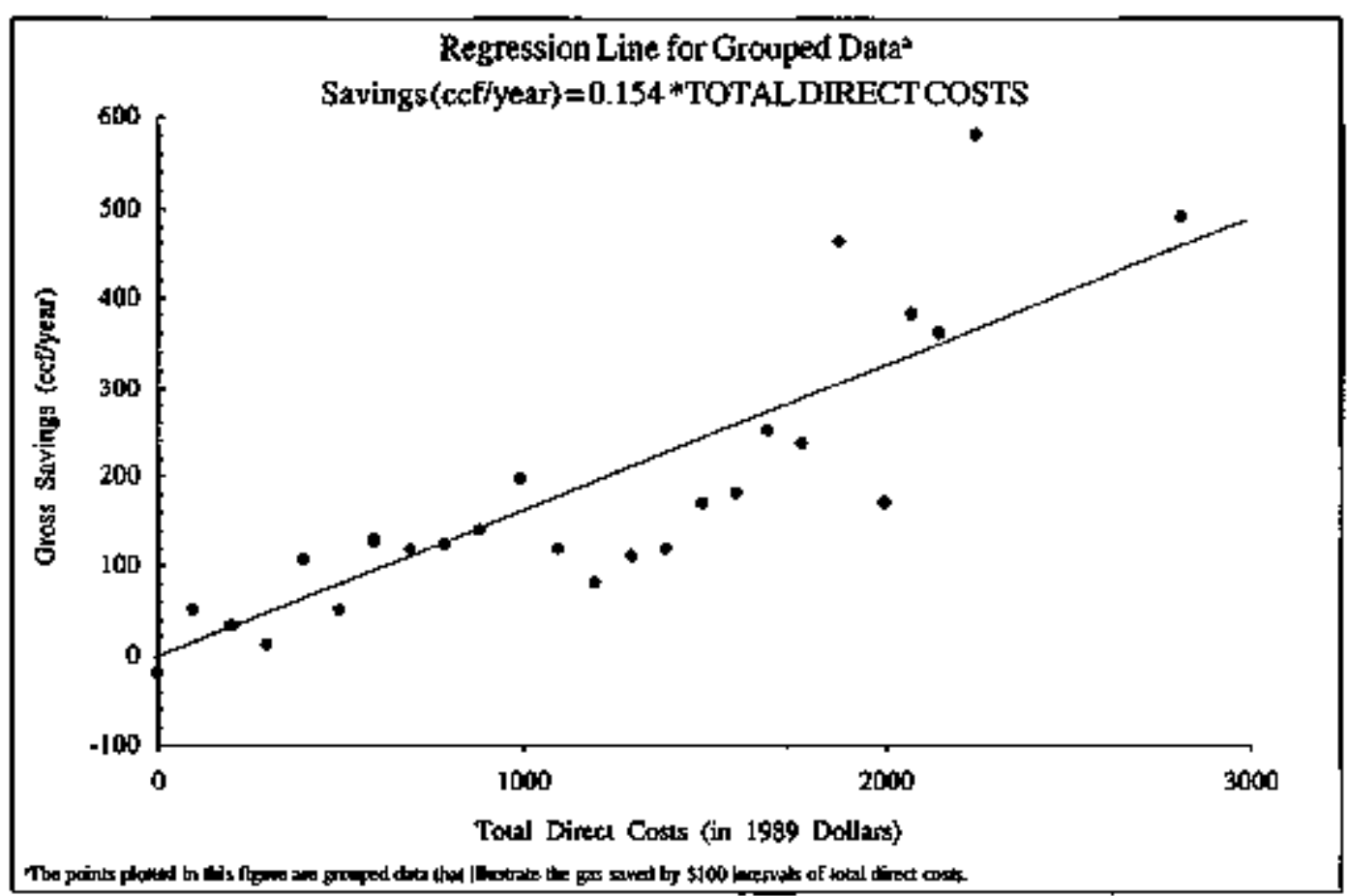

Relationship of Amount Invested in Weatherization Measures to Energy Sarings

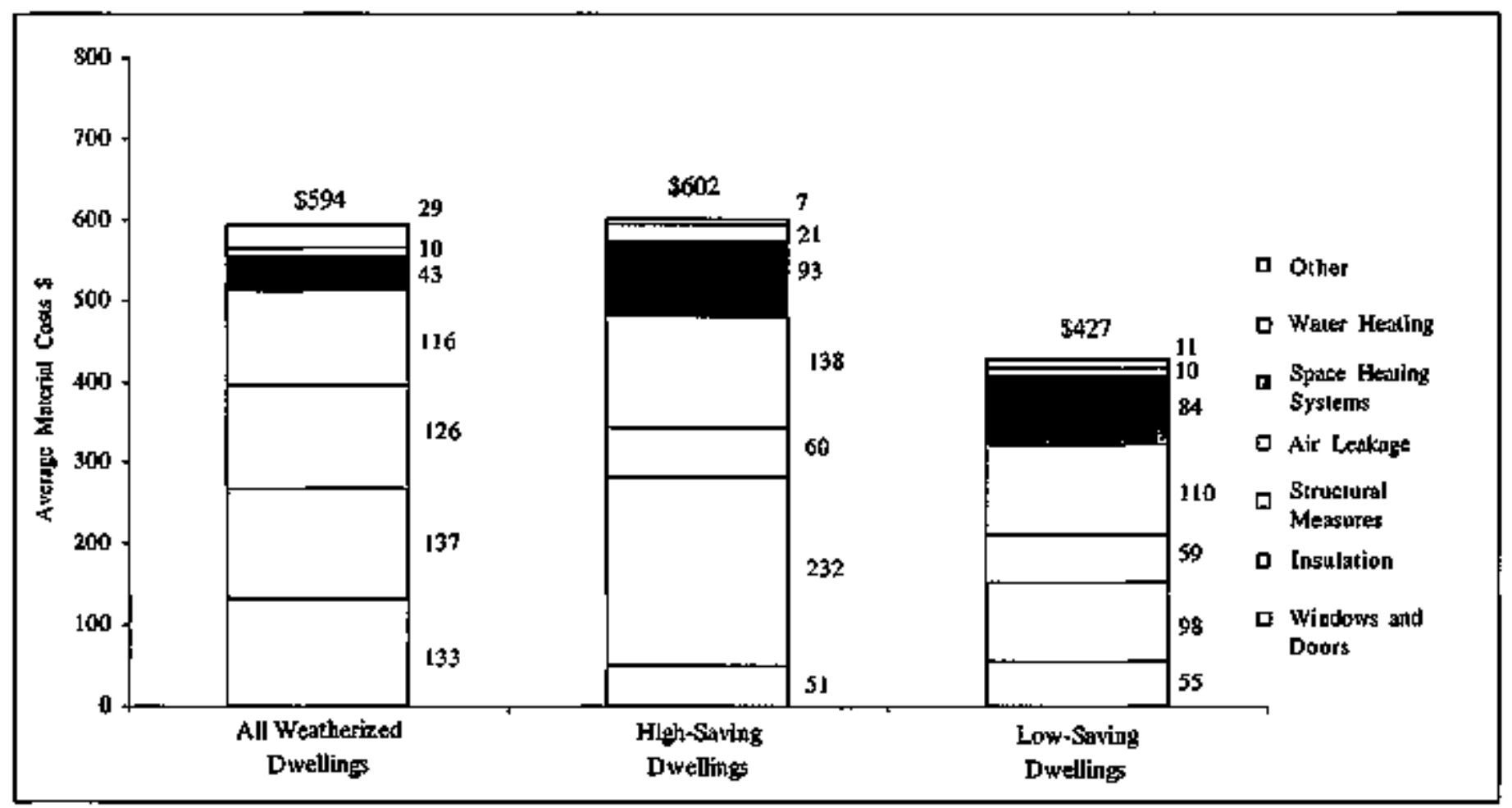

Average Material Costs (in 1999 dollars): A. Weafherized Dwellings vs. Hieht- and Law-Saving Dwellings 
The Warm Climate Initiative began with a Situation Asalysis, in 1994, and a Planning Workshop, in 1995. The Situation Analysis, which was distributed prior to the Workstiop, described current weathenization practices, housing conditions, energy end-use profiles, warm climate issues, and promising new technologies. The Workshop (which brought together Program representatives from all of the warm climate states, several locał agencies, and DOE Headquarters, along with technical experts, and utility representatives) was asked to review the background information, identify the most important issues, and set an agenda for future research and improvements. Many of the Workshop recommendations have now been implemented. An ORNL report assessing cooling measures was completed in 1996, and research on the conditions that determine the effectiveness of storm windows produced preliminary results in the same year. Modifications to the National Energy Audit (NEAT) designed to improve jts usefulness in warm climates ane currently nearing completion. Furthernore, cooperative state-Ievel evaluations in three warm climate states began in 1997 .

\section{REMAINING OPPORTUNITIES}

\section{A. Additional Investments per Home}

Many Opportunlties for Additional Cost-Brrectrve Investments

- Farther jeduce air teakage

- Increase levels of insulation

- Give more attention to heating systems and ducts

- Use more leveraged funds for housingrehsbilications
In general, the amount invested in weatherizing a home is directly related to the magnitude of energy savings. A regression analysis of over 1,800 gas-heated homes showed that gas energy savings increased by 15 ccf/year with each additional $\$ 100$ invested in labor and materials. The average rate of increase in energy savings did not dininish as invesenents increased from $\$ 1,000$ to $\$ 3,000$. In PY 1989 , the average investment per house was about $\$ 1,000$ for labor and materials. Houses that received larger investments, however, clearly saved more energy. For example, high-saving dwellings benefited from total expenditures for labor and materials of $\$ 1,192$, which was $14 \%$ more than the national average of $\$ 1,050$. Low-saving dwellings, however, received an investment of only $\$ 714$ (or $68 \%$ ) of the average national investment. Similarly, highersaving agencies were more likely to obtain funds from non-DOE sources so that a higher average investment per dwelling was possible. These results suggest that there is a cost-effective potential for substantially increasing energy savings by increasing the average investment per dwelling.

The proportion of the funds invested in various types of weatherization measures also is an important determinant of energy savings. In high-saving dwellings, 38\% of the total spent on materials was invested in insulation and $16 \%$ in heating systems. In low-saving dwellings, in contrast, $27 \%$ of the total spent on materials was invested in insulation and $3 \%$ in heating systems. In low-saving dwellings far larger proportions were spent on structural repairs (25\% versus $7 \%$ ) than in high-saving dwellings, and more was invested in windows and doors (15\% versus $4 \%$ ). Similar]y, higher-saving agencies invested more in insulation and heating systems and less in wirdows and doors. 


\section{TARGETING NEEDY HOUSEHOLDS}

\section{LOW-INCOME HOUSEHOLDS AND SUBPOPULATIONS IN 1990}

Low-Licome Households 27.9 Million

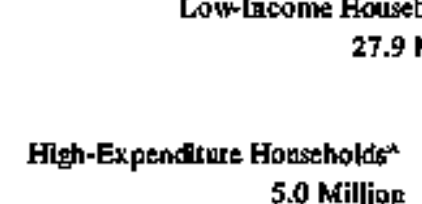

High-Budon \&

High-Expenditure Households

2.1 Million

High-Burden Households**

7.2 Milition

$$
5.0 \text { Milliop }
$$

an 
Many measures installed by the Program show significant opportunities for additional energynefficiency improvements. Although the weatherized homes were clearly tighter than the control homes, approximately $80 \%$ of them still bad air leakage rates that exceeded $1,500 \mathrm{cfm}_{90}$ (a threshold above which more air-infiltration reduction is generally recommended). The R-values in weatherized homes were significantly higher than those in control homes. However, the R-values of the attic insulation in weatherized homes were still often below DOE-recommended levels. For example, about $26 \%$ of weatherized homes had attic R-values of less than R-19 and $63 \%$ had R-values of less than R-30. R-19 or less is below recommended levels in all climate regions in the U.S. and R-30 is below the recommended level for all except the hottest regions. The need for more frequent installations of attic and wall insulation was especially itmpottant in the warm climate region. The poor condition of heating systems and ducts in many homes also pointed to opportunities for additional savings (Berry and Brown, 1994).

Although many important and cost-effective energy-efficiency improvements are being implemented by the Prograra, more funding would make it possible to do mnch more. Because of the overhead costs involved in setting up work in each home, it would be most cost efficient to capure as many opportunities as possible during the DOE-sponsored installation. In addition, because a home will rarely be revisited at a later date, cost-effective measures that are not installed are likely to be longterm "lost opportunities." Leveraged funds from utilities and other sources are an important vehicle for providing more complete and comprehensive weadherization and for minimizing lost opportunities.

Mary low-income homes need extensive structural repairs, which must be paid for with leveraged funds. For these homes, leveraging of housing rehabilitation funds to supplement DOE funds is an essential step in achieving structural integrity and energy efficiency.

\section{B. Targeting the Neediest Honseholds}

The Department of Health and Human Services has reported that, based on Energy Information Administration data, there were 29.1 million households with incomes near or below the federal poverty guidelines for weatherization eligibility in 1994, Given the large population remaining to be served by the Weatherization Program, it is critical for local agencies to focus resources on households with the greatest need for weatherization and with the largest potential for benefiss.

One strategy for targeting weatherization assistance funds is to identify houscholds with both high energy expenditures and bigh energy burdens. High-expenditure households are good targets because high expenditures are correlated with high energy savings potential. Highburden households are good targets because they can least afford the costs of the energy they consume and they are the least likely to be able to make energy-saving investments in their hones.

The 1990 Residential Energy Consumption Survey (RECS) was used to estirnate statistically the size and characteristics of the target groups 


\section{HIGH SAVINGS FROM ATTIC INSULATION}

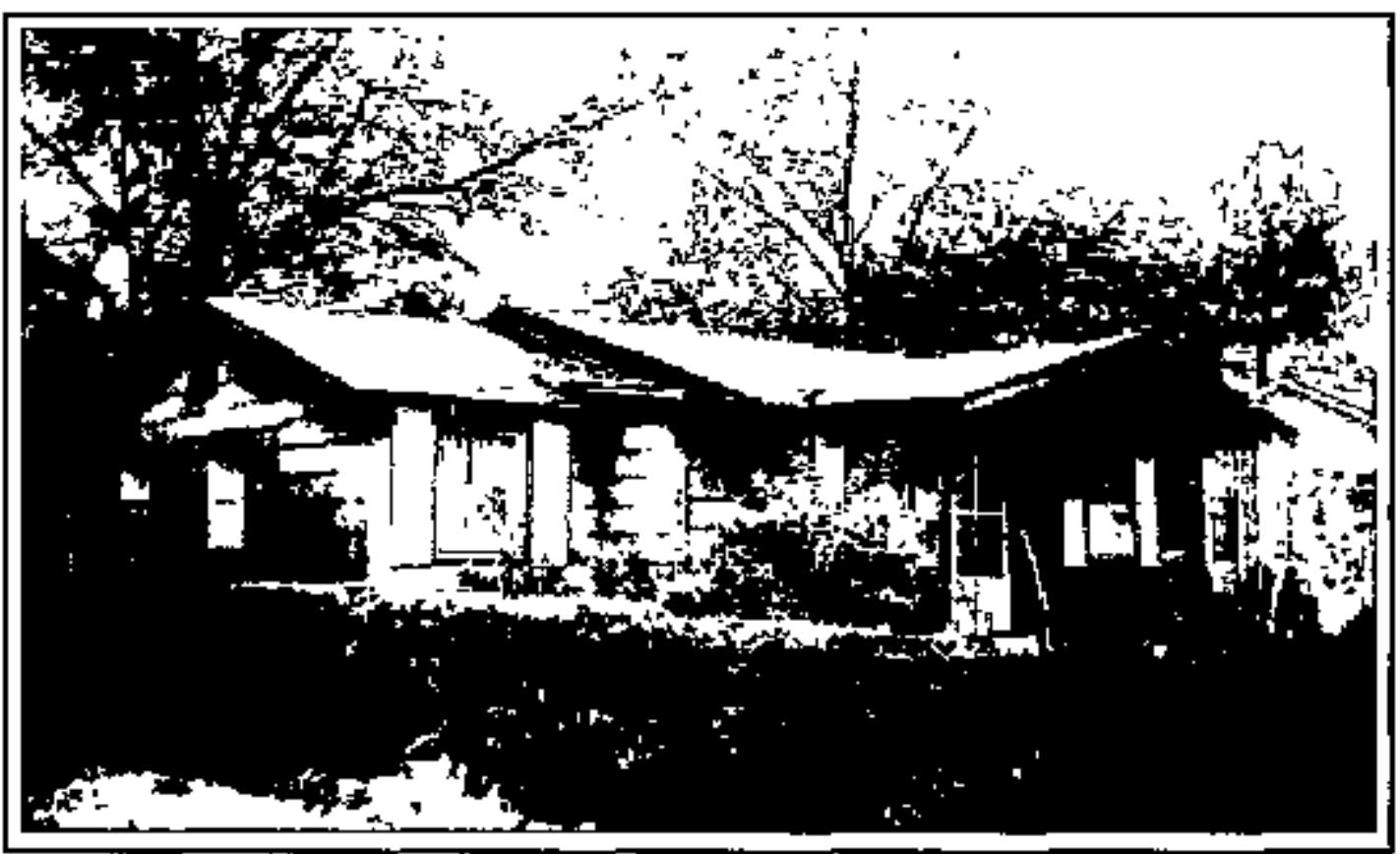

The core of this wood-framed home was built around 1955; since then, two small additions have been constructed, resulting in 1,277 square feet of living space and in a complicated roof-line prone to water and air leakage. Prior to weatheriza tion, the home had no insulation in its attic, walls, or foundation, and its 14 wooden window frames and two wooden doors were rotten and leaky. The home was heated by two gas space heaters-one in the living room and the other in one of the four bedrooms. The 30-gallon water beater and the stove also used natural gas.

The weatherization agency spent $\$ 900$ in materials and $\$ 400$ in labor to weatherize this house. A state-wide priority list of measures was used to select the weatherization measures. The job involved blowing approximately $3^{\text {th }}$ of loose-fill fiberglass insulation across the attic floor, adding two gravity vents for each of the bathrooms, repaining and replacing several windows, replacing one of the doors, and generally caulking and weatherstripping.

During the year after weatherization, the client used $1,002 \mathrm{ccf}$ of natural gas, representing a decrease of $141 \mathrm{ccf}$ (12.3\%). The occupants judged their home to be noticeably less drafty after weatherization and much less expensive to heat.
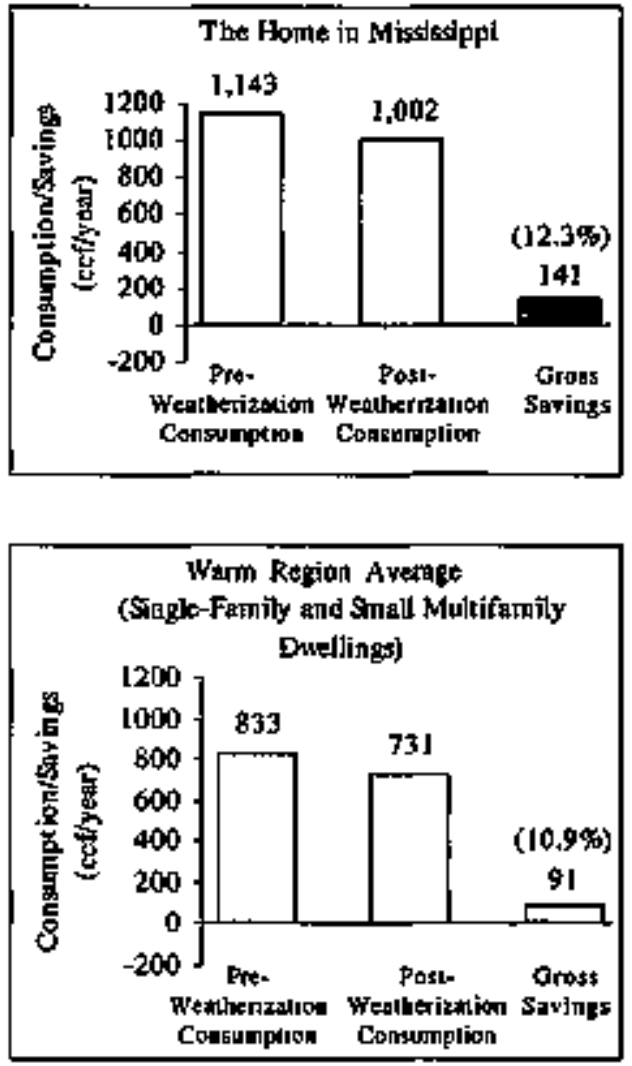
that appear to have the greatest potential to benefit from weatherization assistance. The evaluation defined the groups as follows:

- Figh-Expenditure Households-othose with the highest space heating costs per heating degree day and square foot relative to others in their climate zone and region. This group included 5.0 million low-income households which had average energy expenditures of $\$ 1,233$ and an average energy burden of $19.2 \%$ of income.

- High-Burden Households--those with the highest energy burden (expenditures in proportion to income) relative to others in their climate zone and region. This group included 7.2 million low-incorne households which had average energy expenditures of $\$ 1,175$ and an average energy burden of $30.1 \%$ of income.

- High-Burden/figh-Expendfture Bouseholds--those that qualified in both categories above. This group included the 2.1 million households which had average energy expenditures of $\$ 1,339$ and an average energy burden of $30.4 \%$ of income.

Several key characteristics help to define the High-Burden/High. Expendinure households. These households bave very low incomes-they have an average income of $\$ 6,114$ compared to $\$ 10,048$ for all lowincome households. A substantial share of these households represent vulnerable population groups--about $40 \%$ are elderly bousebolds and another $24 \%$ are single-parent households. In other ways, however, they are much like other low-income households-ttey occupy the same types of dwellings and they use the same types of fuels. Thus, in order to target these households, local agencies need to be particularly attuned to their client's expenditure and burden levels.

\section{THE FUTURE OF WEATHERIZATION: THE NEXT STEPS}

The various reports produced by the National Weatherization Evaluation presented a comprehensive profile of the weatherization procedures and measures that characterized high-performing agencies and high-saving dwellings. The following recormmendations, which resulted from these findings, describe a series of next steps to enhance the Weatherization Program beyond its already strong fonndation.

The Metaevaluation results, which showed an $80 \%$ increase in energy savings during the past seven years, suggest that substantial progress has already been made in implementing many of the National Evaluation's recommendations.

\section{A. Service Delivery Procedures}

- Enhance the existing high quality of the weatherization work force through increased training and professional development. Highperforming agencies were characterized by experienced and well-trained employees. Improving the ability of the weatherization work force to employ diagnostic reasoning and principles from bujlding science will resule $i_{\text {n }}$ even more cost-effective weatherization. 


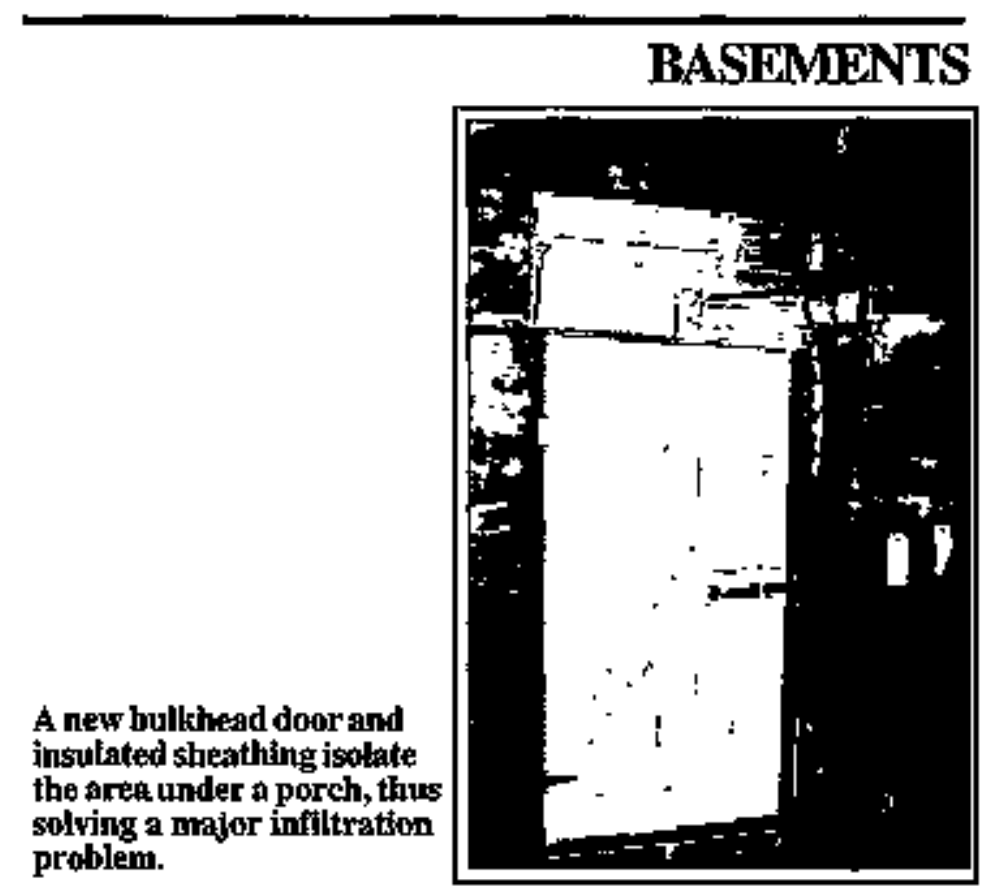

These photos illustrate a weatherization tactic used to block massive infiltration at the bottom of the heated envelope. Sometimes doors or even insulating walls bave to be constructed to form an effective air barrier. Skilled weatherization crews can accomplish this job in two hours or less at a materials cost of only $\$ 60$ or so.

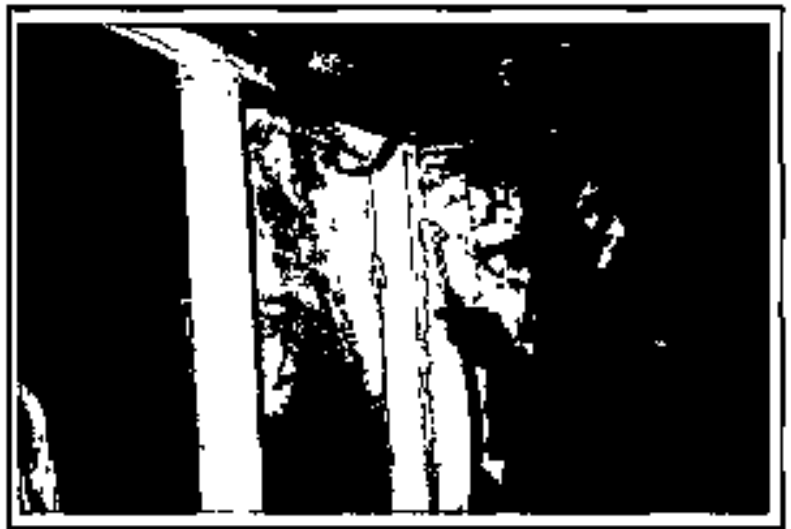

Sealing a new basement partition wall.

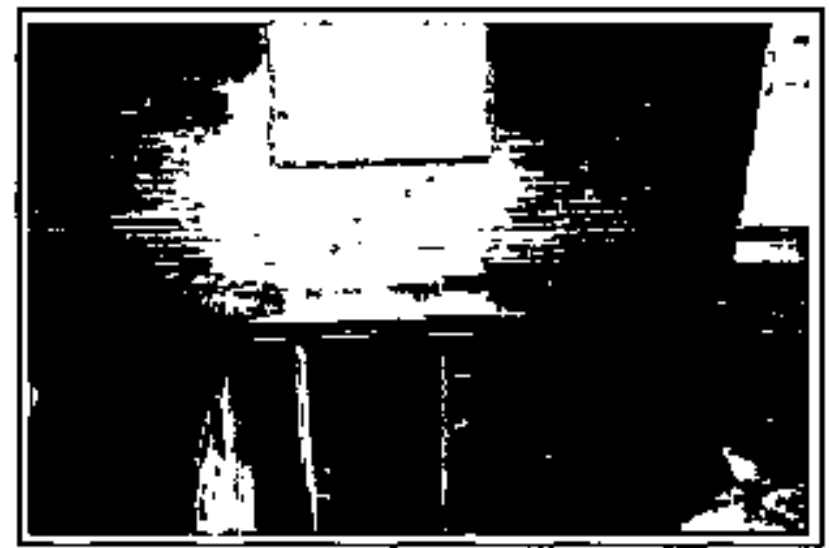

Outside view, bulkhead doors open.

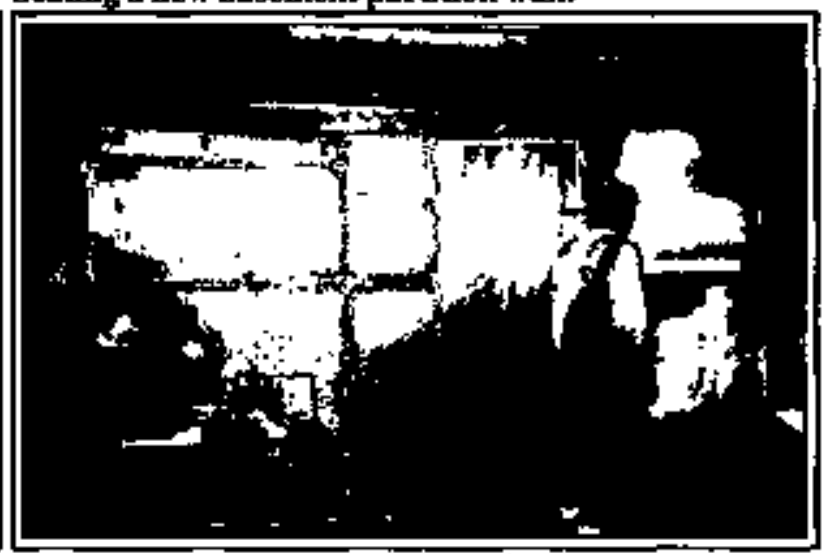

Inside view, new partition wall with weatherstripped access door.

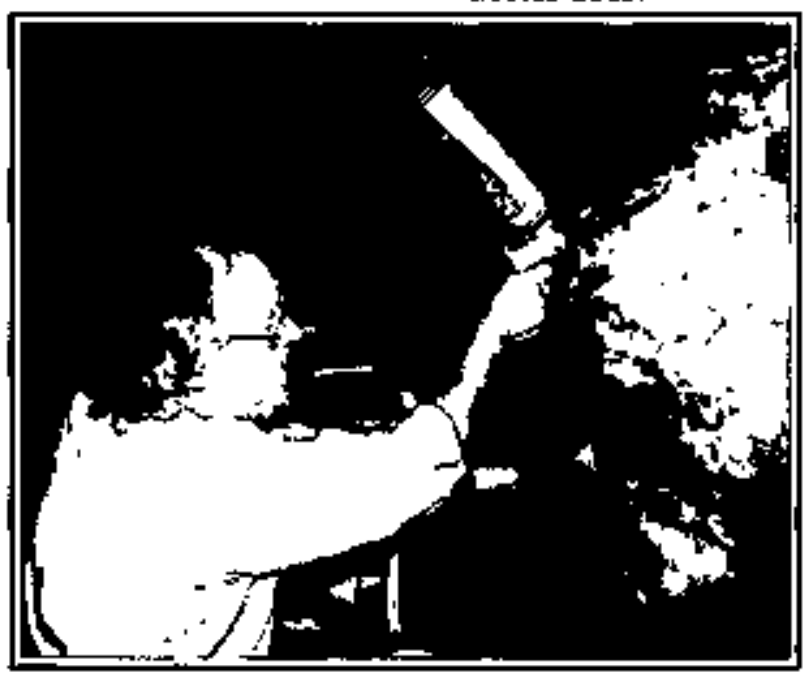

Air sealing at sull plate with foan. This infiltrationstopping measure is necessary with most weatherizathoijobs. 
Technology Transfer Efforts in the 1990's

- Development and promotion of advanced audits

- Warm Climate Initiative

- Development of mabile home audit

- Refined assessment methods for storm windows

- Encourage agencles to direct their resources towards clients that have higher-than-average levels of energy burden. This can be done either through the selection of clients that bave a higher-thas-average energy burden or the determination of investment levels based on the preweatherization energy burden. Both the Single-Family and the Fuel-Oil Studies found that energy savings are greatest in dwellings that consume large amounts of energy prior to weatherization. These same households also tend to spend a high proportion of their income on energy. By matching levels of investment with potential for savings, overall program cost effectiveness will improve.

- Enconrage the efforts of states to mobilize other resources to address the rehabilitation needs of low-income housing. This will enable DOE resources to be focused more on energy-efficiency improvements. Most high-performing agencies have access to non-DOE funds to help pay for housing repairs. The Program will be stronger as more local agencies have access to non-DOE funds for housing rehabilitation while using DOE funds to improve energy efficiency.

- Establish technology transfer mechanisms to promote replication of the success of high-performing agencies. One striking finding of the Single-Family Study is the tremendous diversity among local agencies. A challenge to DOE's Weatherization Program is to help bring the less innovative and less advanced agencies up to the level of the highperforming agencies in their region. The promotion of advanced audits and the Warm Clinate Initiative are two examples of successful recent technology transfer efforts. Additional research efforts that are nearing completion include the development of an audit designed specifically for mobile homes and the development of refined assessment methods for decisions about the installation of stom windows. When these improved tools are adopted by the Weatherization network, additional improvements in performance will result.

\section{B. Weatherization Measures}

- Continue the Program's strong emphasis on attic, wall, and floor insulation. High savings in both the Single-Family and Fuel-Oil Studies are associated with greater-than-average levels of investment in insulation. High-density wall insulation techniques that can achreve air sealing and insulation in the same operation appear to be especially effective. Advanced audits tend to increase the level of investment in both wall and attic insulation.

- Further analyze the role of replacement windows and storm windows. The Single-Family and Fuel-Oil Studies showed that large investments in windows are especially characteristic of dwellings and agencies that achiove lower-than-average energy savings. Yet at least one high-performing agency specialized in storm windows. Further, owner investments in the weatherization of large multifamily buildings tend to target storm windows. Preliminary research, condncted in 1996, has refined assessment methods for determining the conditions under which storm and replacement windows are a cost-effective Program expenditurs. The findings from this research will be incorporated into future versions of the National Energy Audit. 


\section{KEYS TO SUCCESS}

Case studies of ten high-performing local agencies demonstrate that there are many different formulas for the successful operation of a weatterization program. Each of the ten agencies employs a unique combination of useful and innovative approaches. At the same time, common features do exist. The following table summarizes the most notable characteristics that distinguish the ten high-performing agencies fron other agencies. These noteworthy features range from agency and staff characteristics to client recruitment and selection practices; weatherization measures; resource leveraging; and cost controls.

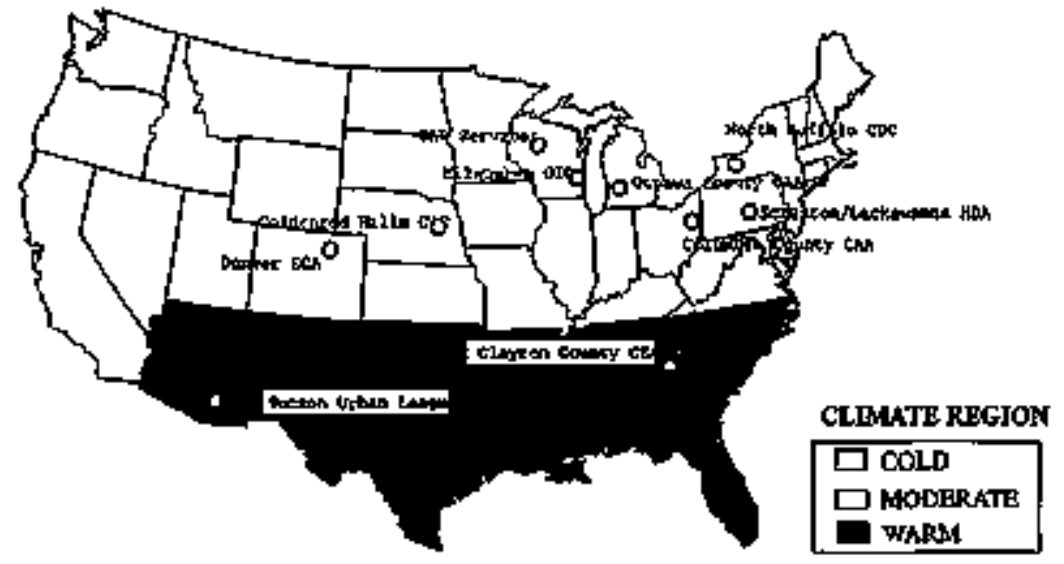

\begin{tabular}{|c|c|}
\hline Category & Characteristies of a Majority of the High Performers \\
\hline Agency Ctaracleristics & Large, mult-pyogram community action agencies \\
\hline $\begin{array}{l}\text { Cheractexistics of } \\
\text { Weatherized Housing }\end{array}$ & 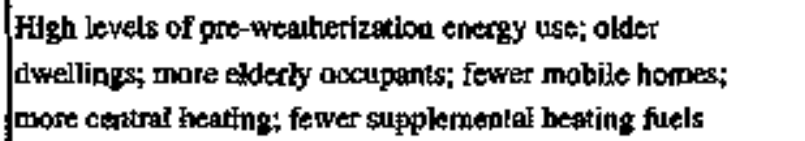 \\
\hline Weatherization Sisff & Limited tomover and substantial weatherization experience \\
\hline Delivery System & In-house crews supplemented by contractors for furnace work \\
\hline Client Recmitnuent & Reliance on LniEAP moters for necrniting applicants \\
\hline $\begin{array}{l}\text { Selection of Clients and } \\
\text { Investunent Levels }\end{array}$ & Strong and increasing focus on high energy users \\
\hline Btower Door Use & $\begin{array}{l}\text { Limiled use in } 1989 \text {, extensive use in } 1996 \text {, daring the audfl, } \\
\text { while air sealidg, and st part of the final inspection }\end{array}$ \\
\hline Wearherization Measures & $\begin{array}{l}\text { More first-lime attic insulation and wall insulation; furnace } \\
\text { retrofits and repiacerpents; and water-heater measures }\end{array}$ \\
\hline Leveragterg Hone Repairs & Access to tousing rehabilitation funds from non-DOE sources \\
\hline Cost Controls & $\begin{array}{l}\text { Effective cost controls such as bulk putrehasing \& in-house } \\
\text { fabrication of theasures }\end{array}$ \\
\hline
\end{tabular}


- Increase the emphasis on replacing inefificient space-heating systems. High-performing agencies identified in the Single-Family Study replaced more space-heating systems than other agencies. In addition, they made greater use of instrumented analyses of furnaces and boilers to select measires that promote bealth, safety, and energy efficiency. System replacements and instrumented analyses were characteristic of highsaving homes in both the Single-Family and Fuel-Oit Sndies.

- Increase attention to heating system distribution systems. Dwellings that received duct leakage control measures and distribution system diagnostics achieved above-average savings in the Single-Family Sukdy.

- Increase attention to water-heating measures. Water-heating conservation measures are characteristic of high-saving homes in the Single-Family and Fuel-Oil Studies. Measures to consider should include domestic warm water tank and pipe insulation, water temperature reduction, low-flow showerheads, and aerators.

- Select measures based on savings-to-investment ratios produced by audits. The Program has successfully moved away from the use of prescriptive methods such as statewide priority lists for the selection of measures. Advanced audits that rank measures by savings-to-investment ratios, calculated for each individual house, were used in 37 states in 1996.

\section{CONCLUSIONS}

Weatherization is a sound public program that has advanced technically during the past seven years. In spite of some impediments, such as reduced funding, the Program is saving $80 \%$ more energy per dwelling and is more cost effective than in 1989. Procedures and measures associated with higher energy savings and new technologies are the major sources of this progress.

Societal benefits resulting from the Program include:

- the creation of about 8,000 jobs (in 1996);

- cleaner air through reduced $\mathrm{CO}_{2}$ and power plant emissions;

- reduced consumption of imported fuels through reduced residential consumption; and

- reduced demand on other social programs such as fuel assistance, housing and health care.

Other benefits include improvement of neighborhood housing conditions, and promoting the use of newly developed conservation tools, materials and techniques. Most importantly, alleviation of the high energy burden faced by low-income Americans enables them to gain increased financial independence and greater flexibility in spending for other essential items.

The table on page 73 compares the findings of the National Evaluation of the Weatherization Assistance Program, based on 1989 data, to the Metaevaluation of 17 state-level evaluations completed in 1996.

To sum up, the Weatherization Assistance Program Works! 


\section{PUTTING IT ALL TOGETHER}

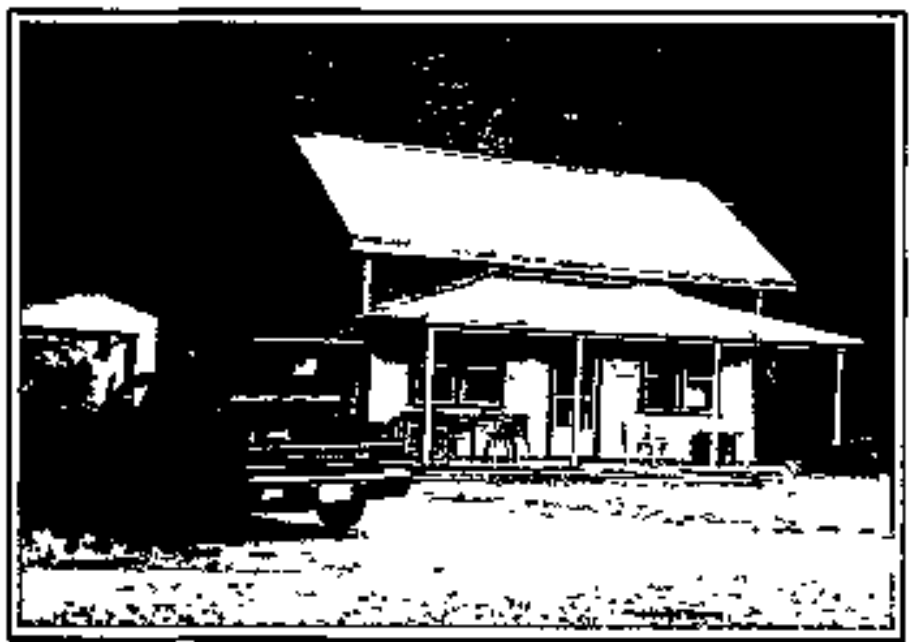

This home in rural New England bad a weatherization job that reduced energy costs by more than 50 percent. After the knee wall on the second floor was accessed with a saw from the outside, extensive air sealing and insulation work were performed. (The access hole is now covered with a rectangular vent) This weatherizaton job also included extensive cepait of a leaky distribution system and other infiltration-stopping measures, including a new basement door. Although exterior aesthetics were not altered, the clients were overjoyed with a much more comfortable house-and a $\$ 600$ per year saving on their oil bill.
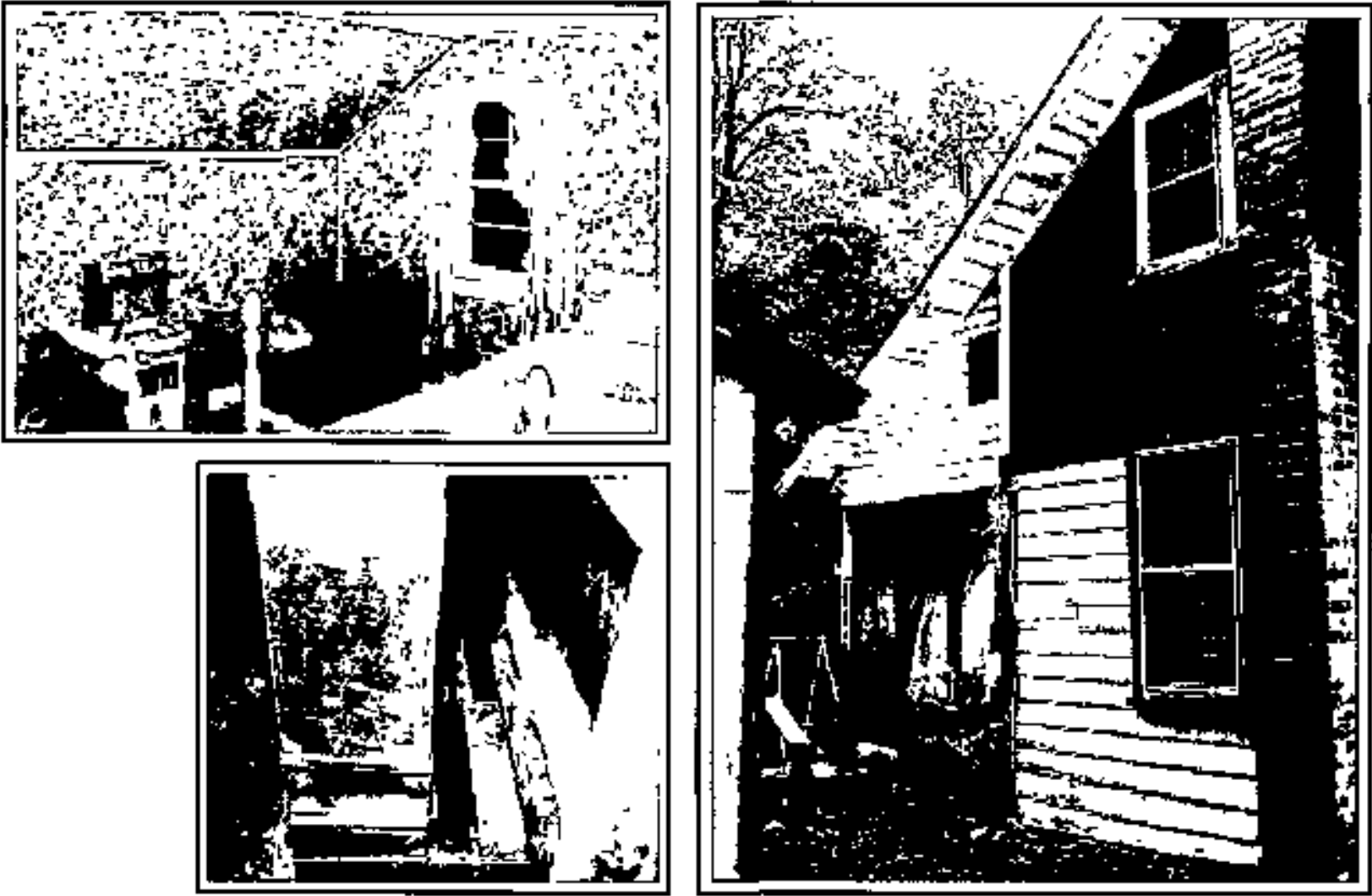


\section{Significant Findings of the 1989 National Weatherization Evaluation and the 1996 Metaevaluation for Gas-Heated Dwellings}

\begin{tabular}{|c|c|c|}
\hline Finding & $\begin{array}{l}1989 \text { Value for Gas- } \\
\text { Heated homes }\end{array}$ & $\begin{array}{l}1996 \text { Value for Gas- } \\
\text { Heated homes }\end{array}$ \\
\hline Annual energy savings per dwelling (in Mbtus) & 17.3 & 31.2 \\
\hline $\begin{array}{l}\text { Energy savings as a percentage of energy used } \\
\text { for space heating }\end{array}$ & $18.3 \%$ & $33.5 \%$ \\
\hline Energy savings as a percentage of total gas consumption & 13.08 & $23.4 \%$ \\
\hline Value of annual energy savings per dwelling in 1996 dollars & $\$ 107$ & $\$ 193$ \\
\hline "Program" benefitloost ratio* & 1.06 & 1.79 \\
\hline "Installation" benefivoost ratio** & 1.58 & 2.39 \\
\hline "Societal" benefit/cost ratio"*** & 1.61 & 2.40 \\
\hline \multicolumn{3}{|c|}{$\begin{array}{l}\text { *Based on energy-savings benefits and total weatherization costs. } \\
\text { **Based on energy-savings benefits and labor and materjals casts. } \\
\text { ***Based on energy-savings, employment, and other non-entergy benefits and total weatherization costs. }\end{array}$} \\
\hline
\end{tabular}




\section{REFERENCES}

\section{This satmmaty is strbstalfially based on the following doctments:}

Berry, Linda G. 1997. State-Level Evaluation of the Weatherization Assistance Progrant in 1990-1996: A Metaevaluation That Estimates National Savings, ORNLCON-435, Oak Ridge National Laboratory. Oak Ridge, Tenn.

Berry, Linda G., and Marilyn A. Brown. 1994. Patterns of Inpact in the Weatherization Assistance Program: A Closer Look ORNL/CON331, Oak Ridge National Laboratory, Oak Ridge, Tenu.

Brown, Marilyn A, Linda G. Berry, Richard A. Balzer, and Ellen Faby, 1993. National impacts of the Weatherization Assistance Program in Single-Family and Small Multifamily Dwellings, ORNL/CON-326, Oak Ridge National Laboratory, Oak Ridge, Tenr.

Brown, Marilyn A., Linda G. Berry, Laurence F. Kinney. 1994. Weatherization Works: Final Report of the National Weatherization Evaluation, ORNL/CON-395, Oak Ridge National Laboratory, Oak Ridge, Tenn.

Brown, Marilyn A, Linda G. Berry, Laurence F. Kinney, James O. Kolb, Thomas C. Wilson, and Dennis L. White. 1993. Keys To Success: Ten Case Studies of Effective Weatherization Programs, ORNL/CON-328, Oak Ridge National Laboratory, Oak Ridge, Tenn.

Brown, Marilyn A., Mark A. Beyer, Joel Eisenberg, Edward J. Lapsa, and Meg Power. 1994. Utility Investments in Low-Income EnergyEffictency Programs, ORNL/CON-379, Oak Ridge National Laboratory, Oak Ridge, Tenu.

Brown, Marilyn A., and Lawrence J. Hill. 1994. Low-Income DSM Programs: Methodological Approach to Determining the CostEffectiveness of Coordinated Partnerships, ORNL/CON-375, Oak Rjdge National Laboratory, Oak Ridge, Tenn.

Columbia Gas of Ohio. 1995. An Administrative Report on the Columbia Gas 1993-1994 Wam Choice Program, prepared by A\&C Enercom, Inc, for Columbia Gas of Ohio.

Bisenberg, Joel F., Eugene Michels, David Carroll, and Nancy Bendux. 1994. The Scope of the Weatherization Assistance Program: Profite of the Population in Need, ORNL/SUB/92-SK904/V2, Oak Ridge National Laboratory, Oak Ridge, Tenn.

Kinney, Laurence F., Thomas C. Wilson, Glemn Lewis, Marilyn A. Brown, and J. Michael MacDonald. 1994. Case Studies of Weatherization in Large Mulifamily Buildings, ORNL/CON-396, Oak Ridge National Laboratory, Oak Ridge, Tenn., Draft. 
MacDonald, J. Michael. 1993. Description of the Weatherization Assistance Program in Larger Multifamily Buildings for Program Year 1989, ORNLCON-329, Oak Ridge National Laboratory, Oak Ridge, Tenn.

Mithlmester, Phillip E., Wallace C. Koehler, Jr., Mark A. Beyer, Marilyn A. Brown, and Darrell A. Beschen, J. 1992. Characterization of the Weatherization Assistance Program Network, ORNL/CON-324, Oak Ridge National Laboratory, Oak Ridge, Tenn.

New York State Energy Research and Development Authority and New York Department of State. 1993. Instrumented Audits Technology Transfer Project, prepared by Synertech Systems Corporation. Energy Authority Report 94-6.

Pennsylvania Public Utility Commission, Bureau of Consumer Services. 1994. LUURP Low Income Usage Reduction Program: Historical Report and Program Anabysis, in collaboration with Pennsylvania State University Consumer Services Information System Project.

Power, Meg, Joel F. Eisenberg, Eugene Michels, Marjorie J. Witherspoon, and Marilyn A. Brown. 1993. Scope of the Weatherization Assistance Program: The Weatherized Population and the Resource Base, ORNL CON-325, Oak Ridge National Laboratory, Oak Ridge, Tenn.

Sharp, Tenry. 1994. The North Carolina Field Test: Performance of the Preliminary Version of an Advanced Weatherization Audit for the Department of Energy's Weatherization Assistance Program. ORNL/ CON-362, Oak Ridge National Laboratory, Oak Ridge, Tenu.

Temes, Mark P., and William P. Levins. 1993. Impacts of the Weatherization Assistance Program in Fuel-On Heated Houses, ORNL/CON327, Oak Ridge National Laboratory, Oak Ridge, Tenn. 


\section{ACKNOWLEDGMENTS}

For additional help in preparing this report, special thaniks to Terry Baxter, Mike Bonn, Connie Cudd, Joel Eisenberg, Ptilip Hayes, Jearne Van Vandren, and Heather Walden. Members of the National Weatherization Evaluation's working groups helped design the National Evaluation, guide its implementation, and interpret its findings. The authors are grateful for their contributions and would tike to acknowledge them individually:

Jef́ Ackemann

Colorado Department of

Locel Affairs

Don Barnelt

Missonri Department of

Naturat Resqurces

Mary Amu Bernold

Edjson Electric Instilute

Jelf Brown

Energy Division,

Nortb Carolina Department of

Commerce

DaleCarning

SaltLake Community Action

Agency

David Carroll

Response Antalysis

Corporation

Mert Dahn

State of Arizona

Department of Commerce,

Energy Office

Margatex Fels

PrincetonUnivers่̀ty Center

for Energy and

Environmenlialşudit:

MichaelFoley

National Association of

Regulaiory Uujlity

Commissioners

Michaeł Ganley

National Rural Electric

Cooperative Association

Richerd Gerardi

New Yod State Dept of Strete

Division of Economic

Opportunity
Sharon Gill

U.S. Department of Energy, Chicago \$uppert Office

Larty Coldberg

SequoiaTechnical Services

Miriam Goldberg

U.S. Department of Energy,

Etergy Information

Adtministration.

Jady Gregory

Center for Neighabothood

Development

Al Guyant

Pablic Services Commission

of Wișconsin

Martha Hewetl

Cenier for Energy and the

Vitaw Enviromment

Bion Howard

Alliance lo Save Energy

Larry Kanmey

Symertech Systems

Corporation

JudithLarkau

Orange and Rockland

Litlikies

Leon Litow

U.S. Department of Health

and Human Services

Ros Marabate

Michigan Department of

Lstor

Bureau of Cormmunity

Services

Jane Marden

Ametican Gas Association
Phil Mtihlmester

Aspen Systoms Corporation

John Milichęll

Consolidared Ediscon:

Company, Inc.

\section{Barry Moline}

American Public Power

Assocjation

John Nelsọn

Wisconsin Gas Company

Korl Pnazek

Director, Community Action

Program Services

Meg Power

Netional Community Action

Foundation

Bill Prindle

Aljauce 10 Save Enercy

Kets Rauseo

The Commonwealth of

Massachuselts

Jeffrey Schlegel

Wisconsin Energy

Conservation Corporation

Kea Tohinaka

Vermont Energy Investment

Corp.

Wendel Thompson

U.S. Depertment of Energy

Marjorie J. Witherspoon Netional Association of \$tate Community Services

Programs 